UNIVERSIDADE DE SÃO PAULO

FACULDADE DE FILOSOFIA, LETRAS E CIÊNCIAS HUMANAS

DEPARTAMENTO DE LETRAS CLÁSSICAS E VERNÁCULAS

PROGRAMA DE PÓS-GRADUAÇÃO EM LITERATURA PORTUGUESA

Alessandro Barnabé Ferreira Santos

Jorge de Sena e a Peregrinação Infecta: das paisagens poéticas que se (não) dão a ver

Versão Corrigida

SÃO PAULO

2017 
Alessandro Barnabé Ferreira Santos

Jorge de Sena e a Peregrinação Infecta: das paisagens poéticas que se (não) dão a ver

Dissertação de Mestrado apresentada ao Programa de PósGraduação em Literatura Portuguesa do Departamento de Letras Clássicas e Vernáculas da Faculdade de Filosofia, Letras e Ciências Humanas da Universidade de São Paulo, para a obtenção do título de Mestre em Letras (Literatura Portuguesa).

Área de concentração: Literatura Portuguesa

Orientadora: Profa. Dra. Mônica Muniz de Souza Simas

Versão Corrigida. Em 29/11/2017

De acordo:

Mônica Muniz de Souza Simas 
Autorizo a reprodução e divulgação total ou parcial deste trabalho, por qualquer meio convencional ou eletrônico, para fins de estudo e pesquisa, desde que citada a fonte. 


\section{FOLHA DE APROVAÇÃO}

SANTOS, Alessandro Barnabé Ferreira. Jorge de Sena e a Peregrinação Infecta: das paisagens poéticas que se (não) dão a ver. Dissertação de Mestrado apresentada ao Programa de PósGraduação em Literatura Portuguesa do Departamento de Letras Clássicas e Vernáculas, da Faculdade de Filosofia, Letras e Ciências Humanas da Universidade de São Paulo, para obtenção do título de Mestre em Letras (Literatura Portuguesa).

Aprovado em:

Banca Examinadora:

Profa. Dra.: Instituição:

Julgamento: Assinatura:

Profa. Dra.: Instituição:

Julgamento: Assinatura:

Profa. Dra.: Instituição:

Julgamento: Assinatura:

Profa. Dr.: Instituição:

Julgamento: Assinatura: 


\section{AGRADECIMENTOS}

Babá mi Ògún Biyi, agò mo jubá! À Iyá Agbá Ana de Ògún, por cujas mãos renasci e diferente não poderia ter sido.

À minha avó materna, Maria Madalena, minha primeira professora, meu esteio.

Ao meu avô materno, Dagmar Launé, pelo exemplo firme e pelas histórias.

À minha avó paterna, Josefina, e ao avô paterno, Lourenço Costa.

Aos meus pais, Ana Cristina e Edvaldo Santos, por serem quem são.

Às minhas tias Helena Launé e Sílvia Launé, por serem mães.

Ao meu tio Nonato Launé, por tudo, hoje e sempre.

Aos amigos de lá, pela compreensão de que o afeto existe mesmo em espaços de entre-distância, como o que passei a viver nestes dois anos e meio:

À Pollyana Bastos, À Mariana Dias, Thiago Abreu, Ana Rosa, Camilla Maramaldo, Gabi Maruyama e todas as "Tias Jogadoras de Truco". À Renata Ribeiro e Vanessa Soeiro e a todos do GEPLIT.

Aos amigos de cá, pelo apoio, pela acolhida, pelos encontros, pelas cervejas, pelos vinhos e pelos porres poéticos, porque disso também é feito pesquisa:

À Izabella Costa, ao Flávio Ismerim, ao Kaio Lages, à Bruna Ramim, à Talita Alves, ao João Flores e ao Leonardo Simões. Vitor Yukio, "obrigado por ter me ensinado a estudar."

À Iyá Egbé Soraia de Iroko, ao Pai Volnei de Oxalá, ao Vine de Logun, ao Bruno de Logun, à Márcia de Oyá, à Cleide de Iyemanjá, à Ekedi Rosa de Oyá, à Márcia de Iemanjá e a todos da família Ilé Àse Ojú Oniré.

À Mariana, ao Renan, ao Guto, ao Rômulo, ao Wendel. À Nicole Guim, ao Paulo César, à Daiane Walker e à Joana Souto.

Ao Luiz Couto, quem me ensinou a não me perder de mim mesmo.

À Márcia Manir Miguel Feitosa, quem me apresentou à poesia de Jorge de Sena e ao universo da pesquisa científica, sobretudo em torno da poesia, em especial da portuguesa.

À Mônica Muniz de Souza Simas, pela amizade, pelo afeto e pela generosidade com que conduziu a minha orientação pelas sendas da poesia de Jorge de Sena.

À Gilda Santos, pelos diálogos constantes sobre a obra de Jorge de Sena.

À Ida Alves, pelos diálogos generosos e cuidados em torno da poesia e da paisagem.

À Annie Gisele, pela leitura atenta na qualificação desta pesquisa e pelas aulas maravilhosas.

À Paola Poma, por ter me feito encantado novamente por Fernando Pessoa.

Ao Caio Gagliardi, pelo interesse por Jorge de Sena e por esta pesquisa.

Ao Emerson Inácio, pela disponibilidade em partilhar conhecimento.

Ao Jorge de Sena, cuja poesia me deu um modo novo de ver o mundo,

Obrigado.

À CAPES, pelo apoio financeiro a esta pesquisa. 


\section{RESUMO}

SANTOS, Alessandro Barnabé Ferreira. Jorge de Sena e a Peregrinação Infecta: das paisagens poéticas que se (não) dão a ver. 2017. 138 f. Dissertação (Mestrado) - Faculdade de Filosofia, Letras e Ciências Humanas, Universidade de São Paulo, São Paulo, 2017.

Jorge de Sena figura como personalidade poética de difícil enquadramento nas searas de produção poética da década de 40 a 60 em Portugal. Não tendo sido um poeta presencista ou neorrealista, nem surrealista ou sequer aderindo fielmente ao fingimento poético de Fernando Pessoa, o poeta português forja uma poética própria a partir da ideia de testemunho e de metamorfose - esta avultando como resultado poético do ato ético-estético da poesia, através da simbiose entre sujeito empírico e sujeito poético. Esta dissertação tem por objetivo investigar a (não) figuração de paisagens poéticas relacionadas aos seus destinos de exílio: Portugal, Brasil, e Estados Unidos da América. Ou seja, o que pode ser visto ou aquilo que é escondido destas e nestas paragens de sua peregrinação infecta, encontrada em sua Peregrinatio ad Loca Infecta (1969), diário tornado objeto estético na configuração ética de seu testemunho circunstancial. Para tanto, a investigação apoia-se nos estudos geográficos de orientação humanista-cultural, bem como nos estudos em torno da relação entre escrita poética e paisagem, desenvolvidos pelo crítico francês Michel Collot.

Palavras-chaves: Geografia Humanista. Jorge de Sena. Paisagens de exílio. Poesia Portuguesa. 


\begin{abstract}
SANTOS, Alessandro Barnabé Ferreira. Jorge de Sena and the Infectious Pilgrimage: unseen poetic landscapes. 2017. 138 f. Dissertação (Mestrado) - Faculdade de Filosofia, Letras e Ciências Humanas, Universidade de São Paulo, São Paulo, 2017.

Jorge de Sena figures as a poetic personality of difficult framing in the poetic scene production from the 40's to 60's in Portugal. He was not a presentialist or neorealist poet, nor surrealist or even adhering faithfully to Fernando Pessoa's own poetics. This Portuguese poet forges a poetics of his own from the idea of testimony and metamorphosis - which stands as the poetical result of the aesthetic and ethical act of his poetry, that occurring through a symbiosis between the empirical subject and the poetic subject. This thesis investigates the figurations or not of poetic landscapes related to his destinations of exile: Portugal, Brazil, and United States of America. Therefore, what can be seen or what is hidden from these places and in these spaces of his infected pilgrimage, in his Peregrinatio ad Loca Infecta (1969), an infectious diary turned into an aesthetic object in the ethical configuration of his circumstantial testimony. To do that so, this investigation is supported on geographic studies from a humanistic and cultural orientation, and also upon the studies concerning to the relation between poetry and landscape promoted by the French schollar Michel Collot.
\end{abstract}

Keywords: Humanistic Geography. Jorge de Sena. Landscapes of exile. Portuguese Poetry. 


\section{SUMÁRIO}

\section{RUMO À PEREGRINAÇÃO INFECTA}

2.1 Jorge de Sena e o diário infecto: aspectos iniciáticos

2.2 Jorge de Sena e a perspectiva do desterro em poesia

3. ENSAIOS SOBRE A PEREGRINAÇÃO AOS LUGARES INFECTOS .........................31

3.1 Jorge de Sena e o Minotauro: ao desterro, sempre! ................................................................. 31

3.1.1 Da geograficidade ao dedo sujo de "investigar as origens da vida"...............................31

3.1.2 De fendas e fissuras: Jorge de Sena e a consciência poética ..........................................40

3.1.3 Regresso aos "Paraísos Artificiais": Portugal e Creta ……………………….....................45

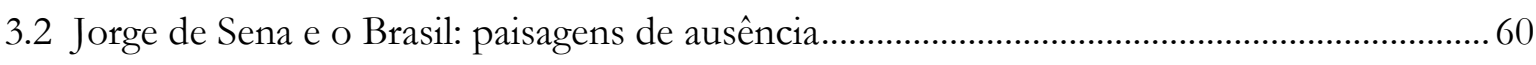

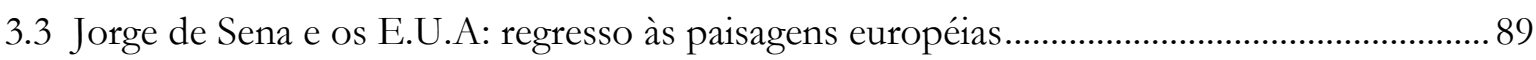

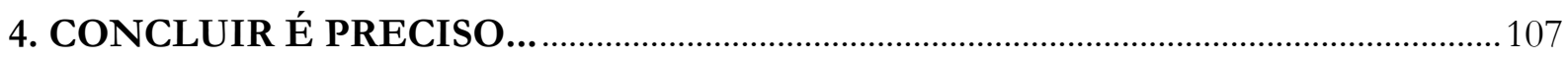

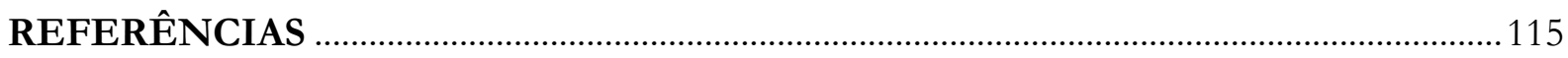

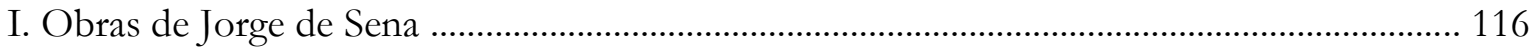

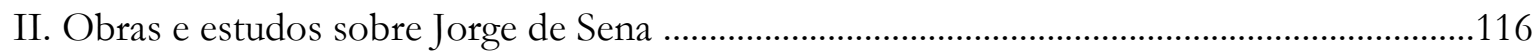

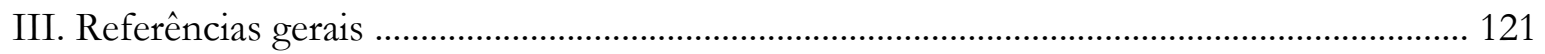

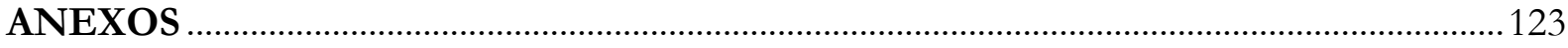

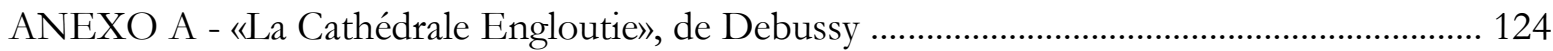

ANEXO B - Carta aos meus filhos sobre os fuzilamentos de Goya ........................................ 126

ANEXO C - Em Creta, com o Minotauro ………………….........................................................128

ANEXO D - O ecumenismo lusitano ou a dupla nacionalidade ....................................................130

ANEXO E - À memória de Kazantzakis, e a quantos fizeram o filme «Zorba The Greek»....131

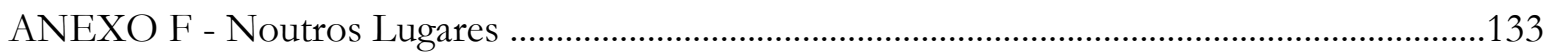

ANEXO G - À memória de Adolfo Casais Monteiro ...............................................................135

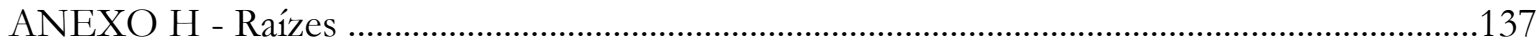


E o poema cresce tomando tudo em seu regaço

E já nenhum poder destrói o poema.

Insustentável, único,

invade as casas deitadas nas noites

e as luzes e as trevas em volta da mesa

e a força sustida das coisas

e a redonda e livre harmonia do mundo.

- Em baixo o instrumento perplexo ignora

a espinha do mistério.

- E o poema faz-se contra a carne e o tempo.

Herberto Helder 


\section{INTRODUÇÃO}

Poesia e paisagem, literatura e geografia: diálogos, pontes e atravessamentos. De onde nasce o desejo de construção de uma pesquisa fecundada pelo diálogo entre temas e áreas aparentemente tão distantes? Se se volta o olhar para os estudos em torno da categoria espaço, na literatura, é possível perceber uma certa tradição de investigações que tomam por objeto a prosa, sobretudo o romance e o conto, formas nas quais esta categoria parece mostrar-se de modo mais evidente. Espaço, não a paisagem, contudo. De fato, o espaço torna-se importante enquanto ambiente no qual a ação narrativa transcorre pelas mãos das personagens.

Dessa perspectiva tradicional, a consideração do espaço como cenário, ou ambiente, onde a ação toma lugar parece reduzir as potencialidades de uma compreensão outra que leve em consideração a interação entre espaço e personagens. Além de ser lugar de ação, o espaço pode também ser entendido pela via da experiência das personagens, no que pode afetá-las. Isso fica mais evidente quando se volta o olhar para um movimento epistemológico interno à ciência geográfica de base parcialmente fenomenológica acerca da concepção de espaço e, de maneira mais íntima, do lugar, a partir de uma perspectiva de interação mútua entre o sujeito e tudo aquilo que o circunda.

Este modo de percepção do espaço, na literatura, interessou em muito a uma certa parcela de geógrafos em meados do século 20, momento em que começam a aparecer estudos de paisagens a partir de uma perspectiva fenomenológica, como aponta Holzer (2008) ${ }^{1}$. De base fenomenológica, a Geografia Humanista surgirá como perspectiva que lança um novo olhar entendimento acerca do espaço percebido e das suas interações com o sujeito, mas somente por volta da década de 1970. Até então, a ciência geográfica era dominada por um viés matemáticoanalítico oriundo de uma perspectiva cartesiana, como esclarece Brosseau (1960) no excerto citado adiante.

Desta geografia analítica e matemática, preocupada com a descrição e verificação de dados matemáticos que ignoravam a presença do elemento humano em torno de espaços físicos e suas

\footnotetext{
${ }^{1}$ A partir do tracejo histórico proposto por Werther Holzer, em sua “A Geografia Humanista: uma revisão”, surgida na Edição Comemorativa da revista Espaço e Cultura (UERJ), tem-se os seguintes nomes numa trilha de desenvolvimento de uma perspectiva geográfica de caráter humanista: 1) Sauer, em 1925, com a proposta de estudos de paisagens a partir do escopo da fenomenologia. 2) John Kirtland Wright, em 1947, com seu discurso em prol do estudo "[...] da imaginação que povoa a mente de todos nós, e que levasse a geografia para além do plano acadêmico que a sujeita aos métodos de análise objetivos." (HOLZER, 2008, p. 138); 3) David Lowenthal, que revisita a obra de seu antecessor, na tentativa de renovar a Geografia Cultural. 4) Yi-Fu Tuan, em 1961, com o desenvolvimento de estudos dos afetos do homem em torno de lugares.
} 
interações, à Geografia Humanista há um salto epistemológico feito pela via do entendimento ou mesmo da inserção do fenômeno da percepção do sujeito em seus estudos. A partir desse entendimento, a Literatura, sobretudo a narrativa, passa a ser campo de interesse de geógrafos humanistas que, num primeiro momento, buscavam enxergar no romance o substrato geográfico que pudesse validar alguma teoria sobre o espaço que, de todas as formas, era anterior à obra analisada:

\begin{abstract}
No início dos anos de 1970, emergia a geografia humanista paralelamente a uma corrente crítica de inspiração marxista, em reação contra a "nova" geografia quantitativa, dominante há uma dezena de anos. Procurando colocar o sujeito (um pouco abandonado, em favor dos bancos de dados) no centro de seus trabalhos, numerosos geógrafos, evocando de maneira mais ou menos direta a fenomenologia, promoveriam a utilização da literatura. Esta podia servir de fonte preciosa, capaz de avaliar a originalidade e a personalidade dos lugares (sense of place) e fornecer exemplos eloqüentes de apreciação pessoal de paisagens. (BROSSEAU, 1960) ${ }^{2}$
\end{abstract}

Por esse viés, a obra literária passou a servir, aos estudos geográficos, como alicerce de validação de alguma teoria geográfica previamente dada. Ora, o geógrafo permaneceria preso, nessa condição, aos bancos de dados, com a diferença de que eles a partir dali viriam da obra literária. Não seria errado dizer, então, que essas primeiras tentativas de inserção do romance no plano de análise e validação de percepção de lugares e sentimentos de espaço, a despeito de seus esforços bem-intencionados, reduzem de maneira grosseira a obra literária a seus elementos constituintes, e só, como se apenas isso importasse na literatura. Nesse sentido, os esforços de diálogo artegeografia se constituíram em análises sobretudo para a afirmação deste novo saber.

Falou-se da prosa, entretanto, como entender o lugar da poesia no interior das discussões sobre um elemento que parece ter uma importância menor em sua constituição? De que forma entender a figuração da paisagem, na poesia, se se tem em mente uma concepção cartesiana destes termos e a noção de que o espaço teria importância reduzida ou dispensável, sobretudo na lírica, uma vez que a épica, dados os seus aspectos formativos, parece ter algo de espacial que significa e importa? Ora, mudam-se os tempos, mudam-se as vontades, diz o verso clássico de Camões. Mudam-se as perspectivas, muda-se o modo de entender o espaço. E a poesia de Jorge de Sena, sobretudo a de exílio, surge como objeto de interesse bastante significativo.

E então, como perceber a figuração do espaço na poesia moderna e contemporânea (a portuguesa, em especial), inscrita numa tradição de ruptura, em muitos modos diferente da poesia pré-moderna, levando em consideração a constituição de um sujeito poético diferenciado? Ora,

${ }^{2}$ In: CORREAA; ROSENDAHL, 2007, p. 19-20 
basta que se pense, em Portugal, no aparecimento da figura de um Fernando Pessoa - e antes mesmo, a de Cesário Verde -, evento que ainda impacta e assombra pela pujança do projeto poético-estético do fingimento poético repartido, ou vivido em absoluto, na fragmentação do sujeito em seres de biografia própria, os famosos heterônimos. E pós-Pessoa, a própria prática poética de Jorge de Sena?

Já a deslocar essas reflexões para a figura de Jorge de Sena, cuja poesia é o esteio desta dissertação, e ainda em Portugal, mas de um polo oposto, e não exatamente contrário, de que modo ocorre a investigação da paisagem em sua obra poética, sobretudo naquela poesia encontrada em Peregrinatio ad Loca Infecta (1969), diário infecto de andanças pelos espaços de exílio pelos quais percorreu toda a sua vida? Uma paisagem que se apresenta de modo tão peculiar, ou melhor, de modo tão contemporâneo, na medida em que não se apresenta como cenário a ser visto ou contemplado; muito menos como espaço que pudesse servir a interesses geográficos de validação de dados que aquela poesia jamais poderia oferecer?

No espaço de entre-distância feito entre a confissão lírica e o fingimento pessoano, portanto num espaço altamente intervalar entre duas das maiores tradições poéticas da lírica portuguesa - aquela tradição, esta ruptura já inscrita numa tradição outra - a paisagem que aparece na poesia de Jorge de Sena, uma paisagem humanizada, porque somente esta paisagem é a que lhe interessa, adiante fica isso claro, desperta atenção por sua importância: Peregrinatio ad Loca Infecta é feito de sua pura circunstancialidade enformadora. É o tema da peregrinação, do exílio, que dá coesão temática a esta obra feita em trânsito, ou melhor, em peregrinação, daí suas cinco seções terem títulos espaciais.

Perguntei, na primeira linha desta introdução, acerca da origem do desejo de investigação pelas sendas da poesia e da paisagem, promovido nesta dissertação. É um desejo de diálogo nascido não de maneira impositiva ou mesmo autoritária, como se a teoria geográfica necessitasse ser provada pela poesia. Não é o que aqui ocorrerá. O diálogo aqui construído será suscitado pela própria poesia de Jorge de Sena, espaço poético onde a paisagem parece surgir como elemento de relevo, na medida em que não é reduzida a puro vislumbre ou contemplação estética do espaço exterior ao sujeito. A paisagem pode conter este olhar contemplativo, mas não é o que ocorre. $\mathrm{Na}$ poesia de Peregrinatio, a paisagem aparece como interesse humano e enlace (des)afetivo promovido pelo olhar atento e vigilante com que o sujeito do testemunho observa, medita e escreve sobre o mundo.

Neste sentido, esta dissertação, fecundada através do entrecruzamento de saberes e afinidades entre a escrita poética e a paisagem, insere-se num diálogo maior promovido pela 
aproximação entre a Literatura e a Geografia. Da parte dos estudiosos da ciência geográfica, há um contínuo esforço recente de mudança de entendimento da obra literária como banco de dados; da parte dos estudiosos da Literatura, um contínuo esforço para que as categorias geográficas - espaço, lugar e paisagem - sejam não somente instrumentos que se prestam a uma análise rápida da obra da moda, mas que sejam análises vivas e enriquecedoras do e para o horizonte interpretativo da própria obra literária.

O estudo da figuração de paisagens na poesia de desterro de Jorge de Sena segue na linha de estudos de paisagem nas literaturas de língua portuguesa representados nomeadamente pelas pesquisas desenvolvidas e em curso pelas professoras Dra. Ida Maria Santos Ferreira Alves, da Universidade Federal Fluminense, e Dra. Márcia Manir Miguel Feitosa, da Universidade Federal do Maranhão. Ambas lideram o Grupo de Estudos de Paisagem nas Literaturas de Língua Portuguesa $^{3}$, cujas pesquisas partem de referenciais sobretudo da Geografia Humanista - Yi-Fu Tuan e Eric Dardel são gratos exemplos - e dos estudos sobre poesia e paisagem de Michel Collot.

Esta dissertação constrói-se a partir da investigação crítica em torno do tópico da paisagem na poética de Jorge de Sena, em especial na Peregrinatio ad Loca Infecta (1969), obra que recolhe poemas escritos entre os intervalos de 1950 a 1969. Ou seja, poemas de um arco temporal que começa com o poema de abertura do livro, “A Sophia de Mello Breyner Andresen enviando-lhe um exemplar de 'Pedra Filosofal”, e encerra com o último poema, "Ganimedes". Os poemas compreendem, portanto, aos anos em que se abateu à vida do poeta a terrível circunstância dos exílios a que fora compelido, iniciado em agosto de 1959, data em que passa a viver no Brasil com a família, seguida por uma nova e forçada partida, agora em outubro de 1965, para os Estados Unidos da América, onde viverá até seu falecimento a 4 de junho de 1977, em Santa Barbara, Califórnia.

Do cotejo da obra seniana, não só Peregrinatio ad Loca Infecta mas também outras obras poéticas que parecem ter muito a oferecer para a análise aqui realizada, surgiram determinados poemas que dão a ver ou escondem, num processo tipicamente seniano, visões instigantes da paisagem tornada objeto estético em poesia. Não interessa ao poeta pensar a paisagem a partir de uma visão contemplativa, como se se tratasse de um sujeito que, ao ver o horizonte, contemplasse o espaço percebido como coisa externa a si próprio. Antes, na poesia seniana, avulta uma paisagem que se imiscui ao sujeito de modo que homem e paisagem passam a compor um organismo só, no que estes dois elementos, homem e espaço percebido, antes apartados e agora amalgamados,

\footnotetext{
${ }^{3}$ Informações importantes sobre este grupo de pesquisa podem ser encontradas no seguinte endereço eletrônico: «http://www.gtestudosdepaisagem.uff.br/»
} 
alteram-se a si próprios e um ao outro.

Nesta chave interpretativa de leitura da paisagem - paisagem: objeto estético a ser contemplado -, torna-se emblemática a pintura de autoria de Casper Friedrich (1774-1840), "O Peregrino sobre o mar de brumas" (1818). No quadro, duma paisagem clara (brumas) e escura (rochedo) o sujeito observa um espaço amplo e vasto que não lhe penetra em decorrência de sua postura contemplativa. O rosto do peregrino não é visto, seus olhos e a marca de seu olhar, tampouco. Fica no expectador o desejo de à paisagem juntar-se, mas em todas as possibilidades ela escapa, foge. Na via oposta, em Sena, a paisagem parece ser sempre um enlace, um acontecimento que ata o sujeito e paisagem ao instante poeticamente "sujo" que foi e é uma das marcas de seu testemunho poético.

A obra objeto deste estudo compreenderia a um terceiro bloco de construção de poemas, ou mesmo fase, a sinalizar para a simbologia da verticalidade de um edifício sólido, metáfora de que Morna (1985) se vale para dar um entendimento em termos de fases ou períodos, se bem que intercambiantes, da obra seniana. Uma primeira fase corresponderia aos poemas de Perseguição (1942) a Fidelidade (1958), incluindo "Post-Scriptum" 40 Anos de Servidão e Visão Perpétua, e teria como características fundamentais a regularidade métrica, de domínio do uso da imagem, permitindo "[...] que o leitor se aperceba de que está perante um universo extremamente coeso, expressão posta em movimento a partir de uma visão de mundo arquitectural, que, do ponto de vista da linguagem, é visivelmente muito legislado.” (MORNA, 1985, p. 22)

O segundo bloco de poemas de Jorge de Sena corresponderia à reunião de poemas coligidos em Poesia-II: Metamorfoses (1963) e Arte de Música (1968), a exceção de Fidelidade. São obras compostas de meditações profundas do poeta acerca de temas que o acompanharam ao longo de toda a sua vida, suscitadas por objetos de arte e musicais: esculturas, pinturas, etc., no caso da primeira; óperas, no caso da segunda. Enquanto que o terceiro corresponderia a obra seniana escrita e inscrita a partir de Peregrinatio ad Loca Infecta até o seu falecimento, e seriam, de certa maneira, uma maturação do projeto poético no qual o poeta opera sua poesia desde os primórdios de sua vida literária.

O aparecimento oficial da poesia de Jorge de Sena em Portugal remonta ao ano de 1940, no segundo fascículo da primeira série dos Cadernos de Poesia. O poeta assinaria com o pseudônimo Teles de Abreu, artífice que também usaria em sua "primeira" publicação poética "não-oficial" datada de 13 de março de 1939, com o poema "Nevoeiro", publicado num jornal estudantil da Faculdade de Ciências de Lisboa, como ilumina Fernando Martinho (1977), num texto cuja tônica dá-lhe mesmo o título escolhido: "Breve enquadramento da poesia de Jorge de Sena". Parte integrante de um número especial da prestigiada Revista Colóquio/Letras dedicado integralmente 
a Jorge de Sena e a sua obra - poética, ficcional, teatral e ensaística -, esta edição veio à lume aquando da premiação recebida por Jorge de Sena, pelo conjunto de sua obra, em Itália, o Prémio Internacional de Poesia "Etna-Taormina”.

Entre um “surgimento" não-alardeado da poesia de Jorge de Sena em março de 1939 e seu aparecimento oficial; portanto, de sua estreia poética, o poeta escreveu, no prefácio à segunda edição de Poesia-I, coletânea que reúne sua publicação de poesia produzida entre os anos de 1942 a 1955, o seguinte:

[...] como já ficou dito noutra parte, comecei a escrever poemas, pouco importa se bons ou maus, em 1936, no sentido de consciência estética de 'escrita'. O que significa o 'diário poético' de uma testemunha, como sempre desejei, de 38 anos da vida portuguesa, desde que o fascismo se instalou com o estalar da Guerra Civil de Espanha até que desabou fragilmente ao sopro das brisas contraditórias e complexas dos Abris de 1974, que eu julgava que não veria nunca. (SENA, 2013, p. 734).

Desde cedo o poeta entendeu a poesia como compromisso ético de estar no mundo com uma fidelidade genuína à humanidade e ao mundo, porque outros não há, evidenciou sempre a sua poesia, postura esta cujo resultado último materializa-se na finalidade transformadora do poema, acentuada em progressão. Isto significa apontar para um difícil enquadramento de uma poética que se apresenta diferente dos cursos tomados pela poesia portuguesa nos idos das décadas de 40 e 50 do século passado, tarefa que Fernando Martinho (1977) intenta executar ao realizar o percurso de rastro presencista e o de rastro neorrealista, estéticas opostas, em aparência, no entendimento da arte e de sua funcionalidade, que confluem na obra seniana sem que, para isso, o poeta adira fielmente, à modo dos -ismos que tanto evitou, a nenhuma delas.

Como corrente estético-poética que se desenvolve no bojo da Revista Presença, contando com 54 números, publicados entre os anos de 1927 a 1940, sobrevivente mesmo à época em que Jorge de Sena começa a publicar, o ideal de Presença construiu-se através do princípio do esteticismo que apregoa a autonomia da arte frente ao mundo. Teve como diretores José Régio, Gaspar Simões, Branquinho da Fonseca, Edmundo de Bettencourt, Fausto José e António de Navarro, nomes aos quais irão se juntar, posteriormente, Casais Monteiro e Miguel Torga, sobre os quais Jorge de Sena escreveu criticamente, sobretudo no seu Da Poesia Portuguesa, de 1959.

A Revista Presença, "Dando, por um lado, a mão aos modernistas de 1915-25, que ajudou a impor, e, por outro lado, aproximando-se, através de sucessivas gradações e polémicas internas [...] do neo-realismo, que se lhe oporia em dada fase posterior, [...] (LOPES e SARAIVA, 1969, p. 1028), a revista corresponderia em síntese "[...] a um certo ambiente de cepticismo quanto aos ideais oitocentistas e republicanos de progresso que possibilitara a transformação do regime, [...]” 
Nesse sentido, [...] os presencistas aspiram, em geral a uma literatura e uma arte desarticuladas, se não mesmo alheadas, de qualquer doutrina diretamente interventora.” (ibid, ibidem). Ora, quer isto dizer, de modo específico, que esta poética se apresenta como recusa mesma das inovações trazidas pelas estéticas de vanguarda, na tentativa de produção de uma arte pura que a desaparelhasse de certa função social sua.

Seguindo o fio articulador presencista, à arte (à poesia) caberia como preocupação exclusiva seus mecanismos internos de funcionamento e estruturação; o artista deveria, por princípio formal, estar atento ao rigor interno da obra de arte, entendida como produto estético, mesmo que para isso fosse necessário o sacrifício de um certo compromisso social (e ético) da obra com as circunstâncias que envolvem seu contexto de produção. Não é difícil imaginar que Jorge de Sena não haveria de se filiar à Presença, na medida em que, trazer à poesia um movimento de ruptura entre o verso e o mundo, alhear a poesia das circunstâncias que a circunscrevem (a poesia como exercício de linguagem) e o poeta (como ser que está no mundo) é pagar um preço alto demais para uma poesia que, resguardado seu valor estético e formal, nunca o fora somente devedora destes valores, pelo que chama à atenção o grau de ligação com o humano, com o mundo (ou já paisagens?) que nela é imprescindível.

Se a Jorge de Sena não se pode atribuir o epíteto presencista, porque a sua obra poética, tampouco seus escritos acadêmicos e teóricos, não dão a ver esta certa filiação, a despeito do rigor estético e formal que sempre fizeram parte de sua produção literária - sem dúvida rastro de uma influência de Presença, que ele toma para si de maneira tipicamente dialética - também não se lhe pode atribuir o epíteto de uma poética que se construiu a contrapelo dos ideais esteticistas do período, porque entende da necessidade de ser a arte um espaço não só de liberdade de escrita, mas sobretudo um espaço de subversão da ordem posta, a que os contextos da década de 40 e 50 na Europa de maneira geral e, em específico, em Portugal e Espanha, contribuem sobremaneira para a formação e estruturação de sua proposta. Como citado acima, trata-se do neorrealismo.

Assim como a opção presencista se fez sentir como reação literária ao estado de coisas que abatia a Europa, sobretudo Portugal, no período em que se formou, também seria o neorrealismo, mas como alternativa estético-poética estrutura-se numa veia que tem raiz no realismo oitocentista, com o objetivo de tornar presente a ligação da literatura com o povo, de maneiras controversas, é evidente, o que não apaga o ideal estético de compromisso da arte com o mundo. Como estética compromissada com o "real", o neorrealismo forma-se, portanto, em meio a décadas traumáticas para o povo português, assim como o foram também todos os movimentos literários da década de 30 do século 20, como sinaliza Jorge Fazenda Lourenço: 
A maioria dos poetas surgidos a partir dos anos 30 forma-se num período traumático da vida portuguesa, subsequente ao golpe militar de 1926 e à instauração do Estado Novo (1933), cujos efeitos são agravados por dois conflitos internacionais sucessivos e fortemente marcados do ponto de vista ideológico: a Guerra Civil de Espanha (1936-9) e a Segunda Guerra Mundial (1939-45). (LOURENÇO, J., 2010, p. 36)

Conflitos estes sobre os quais Jorge de Sena haveria de refletir e meditar em forma de preciosos poemas de teor e tom políticos, encontrados com larga frequência por toda a sua produção poética, de maneira a chamar a atenção ao caráter sempre ético e fiel de sua poesia ao mundo da vida (circundante), aspecto que poderia ser confundido com uma possível entrega sua aos moldes neorrealistas, o que nunca ocorreu, de fato, porque faltaria àquela poética o rigor estético-formal a ele critério importante. De modo avesso ao que denunciaria poeticamente Ferreira Gullar $^{4}$ décadas depois num contexto brasileiro sobre no poema não caber o preço do pão, aludindo a um esteticismo que desvincularia a arte de sua realidade social imediata, Jorge de Sena, para quem a arte é, além de objeto estético, e talvez por isso mesmo, um objeto de transformação do mundo, une em sua poesia um sentimento de mundo desvelado pelo inerente rigor dos princípios internos e formais de sua poesia.

Para Jorge de Sena, faltava aos artistas ligados ao neorrealismo certo rigor estético, sacrificado em favor do conteúdo social da obra, aspecto que deveria, aliás, prevalecer na estruturação dos objetos de arte. A literatura neorrealista seguiria assim numa composição panfletária direcionada às massas populares (ou deles feita), povo este em sua maior parte analfabeto, como mostravam os indicadores do período ${ }^{5}$. Se de um lado o conteúdo social da obra de arte, bandeira central deste movimento novo, atraía o poeta enquanto poética possível, o menosprezo pelo rigor estético lhe aborrecia em igual entusiasmo.

À parte da efervescência cultural que domina o período de tempo em que o poetaengenheiro começa a escrever, e que culminou no desenvolvimento de algumas estéticas de forte representação para as letras portuguesas, presencismo e do neorrealismo, como se apontou acima, poéticas que se defrontaram ao longo das décadas de 30 do século 20, e que ressoam fortemente no projeto poético do poeta, uma terceira via de influências também se faz notar com grande relevo em sua produção a partir da chegada das influências das estéticas de vanguarda, derivadas de um

\footnotetext{
${ }^{4}$ Conferir o poema "Não há vagas", de Ferreira Gullar, publicado originalmente no livro Dentro da Noite Veloz (19621975). In: Toda Poesia (2010, p. 162), tomo poético que reúne a poesia do poeta maranhense feita entre 1950 e 1999.

${ }^{5}$ De acordo com censos que recuperam dados sobre a educação em Portugal, de 1940 a 2001, a taxa de analfabetismo total, em 1940, beirava $50 \%$ do total populacional. Levando-se em conta o recorte de sexo, a taxa era ainda maior em mulheres. Estes dados podem ser encontrados em: $\mathbf{5 0}$ anos de estatística em educação, vol. 1. Lisboa: Gabinete de Estatística e Planejamento da Educação, 2009. Disponível em: «www.ine.pt». Cf. página 17.
} 
modernismo, que propõem modos novos de se entender a linguagem poética. Em Sena, ressoará a influência surrealista de um André Breton, vista sobretudo em Pedra Filosofal (1950), que “[...] fundia as duas linhagens principais - surrealismo e neo-realismo sem 'ismos' - e desenvolvia outras que vinham já implícitas nos livros anteriores.” (SENA, 2013, p. 741).

Jorge de Sena opera uma espécie de síntese dialética ao aproximar-se na mesma medida em que se afasta destas três tendências modernas - Presença, Neorrealismo, Surrealismo -, somadas a uma recusa dialética ${ }^{6}$ ao fingimento pessoano, como modo de conhecimento e educação poética. Nesse sentido é que, de acordo com Lourenço (1987), tem que:

Jorge de Sena opera uma trans-fusão de poéticas, não persegue senão o seu próprio caminho, e no que toca ao surrealismo deixa claro que este lhe é importante como "técnica", e não como "modismo". Lembrando-se a célebre frase de Rimbaud, pode dizer-se que para Sena o "dérèglement de tous les sens" só significa se for, precisamente, "raisonné", isto é se for um processo de estruturação de um conhecimento no tempo, e não uma fuga a este [...] (LOURENÇO, J., 1987, p. 17-8)

A culminar, portanto, numa seniana poética do testemunho, ou o entendimento de que a poesia é um testemunho de linguagem, produto da experimentação aguda dos sentidos humanos daquilo que se vive ou se viveu no mundo afora, em especial os "locais infectos" da vida do poeta. A poesia feita testemunho representa, em síntese, “[...] um desejo de independência partidária da poesia social, um desejo de comprometimento humano da poesia pura, um desejo de expressão lapidar, clássica, da libertação surrealista, um desejo de destruir pelo tumulto insólito das imagens qualquer disciplina ultrapassada.”, como apontou o próprio poeta numa entrevista de 1954, cujo trecho Lourenço, J. (1987) recupera. A prática do testemunho é, por fim, o modo pelo qual a poesia torna-se capaz de transformar o mundo, no desejo do poeta.

Tendo sido feito este breve tracejo da figura de Jorge de Sena e o de sua poesia, que se alinhavará e tomará consistência nas páginas posteriores, onde tomarão lugar reflexões mais aprofundadas sobre a poética do testemunho e a inserção da paisagem nela, cabe agora que se comente acerca da estrutura desta dissertação, a estruturar-se da seguinte maneira: o capítulo primeiro, dedicado à Introdução dos aspectos norteadores desta pesquisa, e outros dois capítulos: o segundo, que tem como função apresentar a obra a ser analisada em seus aspectos estruturais e temáticos, em dois subcapítulos complementares; o capítulo terceiro é composto de três ensaios

\footnotetext{
${ }^{6} \mathrm{O}$ termo "recusa dialética" refere-se à postura do poeta das Metamorfoses frente à poética pessoana. Trata-se de uma aproximação e afastamento mútuos a uma poética que sempre considerou como o maior exemplo de educação poética. O termo é proposto pela pesquisadora Daiane Walker Araújo (USP), em sua pesquisa de mestrado em Literatura Portuguesa acerca da interface dialética entre a poética do testemunho de Jorge de Sena e o fingimento poético de Fernando Pessoa.
} 
que analisam aspectos específicos acerca da figuração da paisagem no diário poético de Jorge de Sena.

Jorge de Sena e Portugal: da paisagem ao dedo sujo será o ensaio primeiro, no qual será explorada a relação de Jorge de Sena com um Portugal que lhe é opressor. Vive-se um momento de supressão das liberdades individuais (e de imprensa, inclusive), de temor e ditadura, comandada por Salazar. A análise dos poemas buscará encontrar o sentimento de deslocamento que sofre o poeta frente à vida num Portugal absolutamente contrário a tudo aquilo que pensa e entende como humanidade.

O ensaio iniciará com o caráter temporal da obra de Jorge de Sena. Nesse sentido, será fundamental a apresentação do tópico da "circunstancialidade" anunciada pela epígrafe reputada a Goethe. Surgirá na escrita do ensaio a questão da paisagem e o aparecimento de Portugal como visão. Ora, a obra a ser analisada é de 1969, e Portugal já era antes e permanece sendo visão preocupada de Jorge de Sena. O principal poema a ser analisado será "Em Creta, com o Minotauro", cujo conteúdo instigante dialoga com toda a obra seniana.

Jorge de Sena e o Brasil: paisagens ausentes é o ensaio segundo, no qual será mostrada a constituição e sobrevivência do poeta em seu primeiro desterro fora de Portugal e a sua relação além-mar com a sua terra natal e com a terra de chegada, o Brasil. A relação de Jorge de Sena com sua muito amiga Sophia de Mello Breyner Andresen deverá aparecer neste ensaio, num possível exercício de por em contraponto a postura do testemunho, em poesia, e a da confissão, no espaço epistolar e de traço afetivo.

O ensaio buscará apontar o que há de Brasil na poesia seniana, se é possível haver. Os poemas que evidenciarão o rastro de uma imagem consistente e profunda de Brasil serão bastante significativos. O Brasil, apesar da ausência escrita e inscrita em poemas, é delineado pela ausência, a partir de uma relação afetiva de fina tensão, como era a do poeta com o seu Portugal distante.

Jorge de Sena e os EUA: do regresso à paisagens europeias é o ensaio último e buscará mostrar a constituição e permanência do poeta em seu último destino de exílio, em solo norteamericano, dialogando com o ensaio primeiro, na medida em que refletirá sobre o término de sua peregrinação. Junto do Minotauro com quem toma o amargo café, misturado pelo famigerado "dedo sujo" que é marca do poema e, penso, de sua própria poesia.

O ensaio terceiro poderá seguir de maneira análoga ao ensaio segundo, não fosse pelo fato de que, se na seção "Brasil” há uma ausência de Brasil, ou do Brasil enquanto paisagem, a seção "Estados Unidos da América" dará indícios de paisagens americanas. Nesse sentido, o ensaio 
buscará entender essa presença, em contraste com a ausência anterior, e, sobretudo, que paisagens são estas que figuram na seção americana de sua obra. Assim, terá sido percorrida toda a peregrinação de Jorge de Sena por seus espaços de exílio, e chega-se à conclusão.

Por fim, haverá a conclusão, espaço onde são discutidas questões como: o que fica da poesia de Jorge de Sena, sua importância para a cena portuguesa de depois. Figuração de Jorge de Sena como poeta incontornável das letras portuguesas do século XX. O que se aprende e se apreende de sua lição de testemunho, o que fica para os poetas que o sucedem. Tem-se, pois, o fechamento das questões postas, das hipóteses inaugurais desta pesquisa, e o desejo de manter vivo o interesse pela obra de um poeta tão singular e instigante como é Jorge de Sena.

E, antes, um alerta de ordem metodológica: a obra poética de Jorge de Sena pode ser encontrada em três publicações distintas: a primeira edição sai sob os títulos Poesia-I (1961), PoesiaII (1978) e Poesia-III (1978). Esta coletânea saiu sob o selo Círculo de Poesia da Moraes Editora e compreende, no primeiro volume: Perseguição (1942), Coroa da Terra (1946), Pedra Filosofal (1950), As Evidências (1955) e Post-Scriptum (1960). No segundo volume: Fidelidade (1958), Metamorfoses (1963) e Arte de Música (1968). O terceiro volume: Peregrinatio ad Loca infecta (1969), Exorcismos (1972), o poema “Camões dirige-se aos seus contemporâneos" (1973), Conheço o Sal... e outros poemas (1974), Sobre esta praia... Oito meditações à beira do Pacífico (1977).

Há uma reedição desta coletânea sob a tutela da Edições 70 e publicada entre 1987 e 1989. E, por fim, há ainda uma novíssima edição da obra poética de Jorge de Sena, publicada pela Guimaraes Editores, e organizada por Jorge Fazenda Lourenço. Esta edição é composta por dois tomos: Poesia 1 (2013), que compreende toda a obra poética reunida e publicada em vida; e Poesia 2 (2015), reunião da obra poética póstuma. Para esta dissertação, será usada a edição mais recente, a de Jorge Fazenda Lourenço, por trazer, ao pé dos poemas da Peregrinatio ad Loca Infecta a data completa de produção dos poemas, e não tão somente o ano, como na edição do Círculo de Poesia, enfatizando o traço de diário que é importante na obra. 


\section{RUMO À PEREGRINAÇÃO INFECTA}

\subsection{Jorge de Sena e o diário infecto: aspectos iniciáticos}

O título da obra a ser investigada, Peregrinatio ad Loca Infecta, dado por Jorge de Sena de modo irônico e caricatural a uma Peregrinatio ad loca sancta, “[...] espécie de guia e relatório devoto, artístico e prático do peregrino da Terra Santa, que constitui um dos mais preciosos documentos existentes para o estudo do latim vulgar.” (SENA, 2013, p. 453), é pleno de sentidos e dá a ver algumas questões importantes que chamam a atenção para a presença da paisagem - loca infecta em sua obra: o título suscita um pensar sobre a paisagem porque anuncia um percurso de peregrinação, ou mesmo, um vagar no mundo a esmo, com toda a sua larga tradição religiosa que remete às peregrinações cristãs por lugares sacros, ou antes tornados sacros pela via historicidade e geografia humanas.

$\mathrm{O}$ adjetivo infecto com o qual o poeta caracterizou os lugares pelos quais percorreu como "peregrino" nada tem em relação a um qualitativo de ordem negativa que pudesse indicar infecção ou rejeição pessoal da jornada trilhada e dos espaços que o acolheu em seus múltiplos exílios. Sobre essa possível chave interpretativa, por antecipação explicitou o contrário, num prefácio de tom confessional sob o título "Isto não é um prefácio", no qual esclarece de modo rigoroso: "Mas não se deve, de maneira alguma supor que a ideia de 'peregrinação aos lugares infectos' possa ser assimilada a uma expressão das amarguras de ser-se um 'peregrino da América', , como tenho sido, e da Europa por fim, há cerca de dez anos.” (SENA, 2013, p. 453) Os lugares de que fala o poeta são infectos precisamente porque a visão que deles se imprime é aquela mesma visão profunda, extraída de uma "vigilância" atenta, contínua e consciente que ele tem do mundo, da poesia e da

\footnotetext{
7 “Isto não é um prefácio" poderia ser o título de todos os prefácios que acompanham as publicações existentes da obra de Jorge de Sena. Com efeito, aquilo a que convencionalmente chama-se prefácio converte-se na obra do poeta em verdadeiros ensaios e meditações acerca de sua poesia, estes realizados com a intenção de fornecerem um guia orientador da leitura dos poemas que ali vão escritos, uma preocupação constante na vida de um poeta que fora obrigado a lidar por longo período com a alcunha de intelectualista, para não dizer hermético, dado o modo como seus primeiros leitores enxergaram a sua poesia. Aliás, a impossibilidade do entendimento de sua poesia (ou mesmo mávontade da crítica especializada em lê-lo) foi sempre uma das grandes amarguras do poeta para com a sua terra, Portugal e sua gente.

${ }^{8}$ Jorge de Sena faz “[...] alusão ao romance didáctico (e tremendamente medíocre e enfadonho) Compêndio Narrativo do Peregrino da América, Lisboa, 1728, de Nuno Marques Pereira, que os primeiros historiadores da literatura brasileira, no seu afã de escrever patrioticamente do que não havia, desenterraram do esquecimento em que havia caído (após ter conhecido, ao que se diz, grande sucesso ao tempo da publicação), para desempenhar o papel histórico de primeira obra brasileira de ficção." (SENA, 1969, p. 23) Trecho de nota explicativa acerca do "peregrino da América". O poeta comenta, ainda, que a crítica brasileira à época já não considerava a obra de tanta importância, não tanto por suas qualidades estéticas internas, mas pelo fato de que se descobriu a não-naturalidade brasileira, e sim portuguesa, de seu autor.
} 
humanidade. Uma vigilância expectante como aquela observada no instante imagético-sonoro da queda do vaso da China, durante a audição da peça de Debussy, de onde sai apenas papéis velhos e sujeira.

Do aspecto aparente do título, parece estar claro o percurso desta investigação, que se fortalece quando se volta o olhar para o interior da obra: composta de cinco partes unidas em perfeita comunhão e coerência: Portugal (1950-59), Brasil (1959-65), Estados Unidos da América (1965-68/69), Notas de um regresso à Europa (1968-69) e um Epílogo. Os intervalos temporais entre os parênteses de cada seção do livro compreendem exatamente às datas de produção dos poemas que as compõem. E não só, o título de cada seção indica, também, o espaço geográfico em que cada bloco de poemas foi composto; são, portanto, índices espaço-temporais a apontar para as circunstancias específicas de exílio que enformam e contribuem para a coerência interna desta Peregrinatio ad Loca Infecta.

Para além da questão titular de cada seção da obra, como dito acima, mas bem próximo a ela, Jorge de Sena utiliza um recurso que chama a atenção para as relações dialogantes mantidas com outros poetas, dispostas sistematicamente nas diversas epígrafes que povoam a sua obra. $\mathrm{O}$ poeta-engenheiro e quem sabe mesmo em função de sua formação científico-matemática, usa o recurso da epígrafe como modo de apresentação justa e de plena concordância com os temas gerais de cada bloco de poema. No transcurso de sua obra, as epígrafes têm grande significado, porque, além de dialogarem com a sua poesia, fornecem rastros de leitura do poeta. Assim é que na seção Portugal o que prevalece é o rastro camoniano dOs Lusíadas:

Eis, quase cume da cabeça de Europa toda, o Reino Lusitano

(CAMÕES, canto III, 20)

(In: SENA, 2013, p. 455)

Essa epígrafe é farta de sentidos quando se entende que ela cumpre uma função dialogante com os poemas que compõem a seção. Camões foi uma grande obsessão seniana, quer em sua obra poética - os motes de poemas camonianos dos quais se apropria em versos seus, de maneira, por vezes, a dar-lhe um sentido outro, encorpado ao poema seniano - ou em seus escritos teóricos e ensaísticos, nos quais o poeta empreende importantes análises da obra do herói luso. Ali, na epígrafe, há um indício da importância do reino lusitano para a Europa, um sentimento de grandeza já envolto a certa melancolia ou estado de saudade portuguesa que não é jamais superado; antes, acentua-se e firma-se como particularidade daquela identidade. O corpo de poemas dialoga com essa ideia e põe em evidencia o já não tão mesmo Portugal camoniano. 
No corpo de poemas, questiona-se o lugar de Portugal naquele século XX que é o de Fernando Pessoa, mas também o de Jorge de Sena, duas figuras de personalidades e visão poética tão diferentes. Aqui, nesta seção, a terra portuguesa em sua dimensão completa começa a aparecer, e o próprio país natal já é visto de uma maneira distanciada, ainda que o sujeito esteja vivendo em Portugal. A paisagem portuguesa habita o ser do sujeito, ainda que ele mesmo se encontre em estado de estrangeiramento, e isso aparece de modo curioso em sua poesia. E porque habita, tornase imagem recorrente, como se dará a ver nos ensaios subsequentes.

Logo em seguida, o poeta faz valer os versos de Horácio, quando traz à abertura da seção Brasil a seguinte estrofe:

Quid brevi jortes jaculamur aevo

Multa? Quid terras alio calentes

Sole mutamus? Patriae quis exul

Se quoque fugit?

(Porque, se a vida é breve, tantas cousas

buscamos? Para que terras alheias

por outros sóis candentes? Quem da Pátria

sai a si mesmo escapa?)

(HORÁCIO, Odes, II, 16)

(In: SENA, 2013, p. 467)

A epígrafe serve às meditações que Jorge de Sena empreende em torno do tema do pertencimento à pátria. Os versos finais “Quem da Pátria / sai a si mesmo escapa?” são, de certo modo, uma interrogação que o perseguirá ao longo de toda a sua obra, na medida em que as dimensões que uma específica experiência do exílio empreendem em sua alma de sujeito parecem ser muito maiores do que normalmente seriam: ocorre, no seu caso específico, a ocorrência de exílio adentrado, ou mesmo o sentimento que tem em relação à pátria "de que por acaso de gerações nasci”, como alerta nos versos do conhecido poema "Em Creta, com o Minotauro". É possível ser-se português mesmo em espaços que não Portugal?

Do que vai no bloco de poemas a que compreende a seção Estados Unidos da América, o poeta utiliza-se de versos de Yeats, a inaugurarem poeticamente a ocorrência biográfica de um segundo exílio - ou mesmo terceiro, e derradeiro - pelo qual haveria de passar, aquando da instauração de um duro regime militar no Brasil, espaço onde viveu, adquiriu cidadania, filhos e construiu versos, para além de linhas narrativas e políticas - dada sua participação no jornal oposicionista Portugal Democrático - linhas de força que se misturam fundamentalmente ao longo de sua obra, em suas múltiplas facetas. País onde, aliás, iniciou sua carreira docente como professor de Literatura Portuguesa em São Paulo. Aos versos, aliás, atente-se: 
You think it horrible that lust and rage

Should dance attention upon my old age;

They were not such a plague when I was Young;

What else have I to spur me into song?

(Acham horrível que este cio e raiva sejam que atento dança o meu envelhecer;

não eram uma tal praga em minha juventude.

Que mais eu tenho que a cantar me pique?)

(YEATS - The Spur)

(In: SENA, 2013, p. 525)

Estes versos sinalizam, também, para a forte relação de Jorge de Sena, e de seus amigos do Cadernos de Poesia, com a tradição literária (poética sobretudo) de língua inglesa. E não só: são versos que apontam, talvez numa aproximação forçada, para a mesma postura em relação à tradição inglesa adotada por Fernando Pessoa, que foge da tradição lusa de influência francesa. Sobre estas questões, Fernando Martinho (1982) apontou acerca de um verso do romântico inglês John Clare tornado glosa num poema de Sena, em texto intitulado "Leituras na poesia de Jorge de Sena", datado de 1982, publicado na Revista Colóquio/Letras, em torno da relação mantida pelo poeta com o universo poético anglo-saxão:

A familiaridade com a vida e a obra do poeta romântico inglês John Clare (17931864) suscita a Sena - que, com os seus companheiros de Cadernos de Poesia, muito fizera para abrir as nossas letras ao mundo anglo-saxónico, e, assim, desviá-las da sujeição aos eternos modelos franceses. (MARTINHO, 1982, p. 17)

Já na seção Notas de um regresso à Europa, os versos que abrem o bloco de poemas são de natureza clássica (Safo) e simbolista (Mallarmé). As duas recorrências remetem em evidência clara aos temas gerais de que tratam a obra poética em análise: a perspectiva da viagem, ou melhor entendida como peregrinação, e a experiência de retorno aos lugares pátrios, ou àqueles cuja "camisa" (nacionalidade) o poeta vestiu e deitou fora, "com todo o respeito" à roupa vestida. De Marllarmé, põe-se a questão da viagem, seguida por Safo em seu entendimento de um inevitável retorno daqueles que partem, a partir de específicas metáforas. O retorno é do que trata mesmo a matéria desta seção em específico, retorno a Portugal, retorno a outros países europeus, ainda que por curto período de tempo e jamais em caráter definitivo:

Au seul de voyager...

(MALLARMÉ - Poésies)

Ao lar, Vésper, tu fazes que regressem todos

Que a radiante Aurora aos longes conduziu:

Ovelhas ao redil, as cabras aos apriscos,

E os filhos para ao pé de sua mãe. 
(SAFO)

(In: SENA, 2013, p. 547)

\subsection{Jorge de Sena e a perspectiva do desterro em poesia}

De uma perspectiva mítica com lastro judaico-cristão, a humanidade carregaria em si a marca do afastamento de uma terra natal. Pela via do mito, filha que é do casal original, eles mesmos expulsos do jardim do Éden, a humanidade estaria condenada a viver num espaço outro que não a terra original - Éden - daí estar a humanidade em permanente exílio. Este é o mote com o qual Montañéz (2013) inicia seu estudo sistemático em torno da experiência do exílio, numa escritura que se faz pela oscilação entre teoria e análise e a crítica e a ficção, na obra de Julio Cortázar e Marta Traba. A crítica retoma alguns dos questionamentos fundamentais de Edward Said (2003), sobretudo o conceito de exílio como "fratura incurável", atualizando-os às obras investigadas, caminho que vem a ser de alguma valia na investigação da paisagem, marcada pela circunstância do exílio, na obra de Jorge de Sena.

Se de um lado a perspectiva mitológica judaico-cristã é tão somente isto: mitologia, do que sua validade e veracidade devem ser resguardadas ao campo da ilustração de uma teoria genesíaca de fundação da humanidade; mitologia que, aliás, diz respeito a uma comunidade específica, posto que no mundo cosmogonias outras há que explicam de modos diversos a criação do universo e dos seres viventes. À parte disso, algumas lições podem ser apreendidas da narrativa judaico-cristã, caso se leve em consideração a indicação pessoana contida em Mensagem (1934), o épico moderno feito ao avesso daquele camoniano, de que "o mito é o nada que é tudo."

Ora, o verso clássico de Fernando Pessoa acima citado é, com efeito, o modo perfeito pelo qual o poeta dos heterônimos inicia sua própria fabulação do mito de Ulisses, o guerreiro clássico, como fundador de Lisboa. De regresso a sua terra natal, Ítaca, após os longos vinte anos em que esteve em batalha pela Guerra de Tróia, chega Ulisses àquela porção de terra, através da interferência externa dos deuses e ali teria fundado Lisboa. De mais a mais, o verso pessoano ajuda a entender a experiência do exílio contida no mito cristão e a própria natureza errática de uma civilização que teria, desde os primórdios, sido uma terra de exilados, ou daqueles que partem, alcunha que se estenderia a todo o Portugal.

Portugal é terra dos que partem, poucos são os que ficam, e aqueles que ficam anseiam a partida, disse o poeta das Metamorfoses. A despeito da natureza desse pensamento, o poeta, ele 
mesmo um exilado, constata alguma coisa de essencial verdade na história portuguesa, de sua fundação à contemporaneidade: houve sempre ali, em sua terra natal, um movimento marcado pelo traço fundamental da partida, a começar pelo pioneirismo ibérico das Grandes Navegações, frente a uma Europa ainda medieval e fragmentada; passando pela descoberta de territórios além-mar e pelo consequente fortalecimento do reino lusitano; o nascimento de Portugal enquanto nação. E, por fim, a descoberta do Brasil, que, no devido momento, passa a receber portugueses para habitálo junto aos nativos, a fuga da família real para sua então colônia no século 19 e já no século 20 o levante de uma ditadura comandada por Salazar; são estes grandes fatos que testemunham a partida (de maneira voluntária ou não) de portugueses para terras dispersas no mundo.

Jorge de Sena não fugiu a esta aparente tradição portuguesa vinculada ao destino da partida, nele inscrita sob o signo de uma peregrinação infecta por múltiplos exílios, a começar por seu sentimento de sentir-se um estrangeirado em seu próprio país, "Por um lado, Jorge de sena era um 'estrangeirado' e, pelo outro, alguém que no estrangeiro se refugiara em pleno 'reino da estupidez' nacional" (SIMÕES, 1981, p. 72). Este sentimento haveria de resvalar numa espécie de exilio adentrado. A este sentimento, de que se terá notícias em alguns poemas de Sena - alguns dos quais selecionados para o desenvolvimento desta pesquisa - poderia corresponder muito timidamente a uma espécie de insílio ${ }^{10}$, um dos conceitos-chave junto de exílio e desexiliio ${ }^{11}$, para a estudiosa Volpe (2005), na análise do fenômeno do desterro na obra do uruguaio Mario Benedetti.

A estudiosa Miriam L. Volpe analisa o fenômeno do distanciamento de um sujeito de sua terra natal a partir da experiência latino-americana, suscitada na obra do autor que analisa, e marcante. Experiência esta marcante enquanto dado humano, na vida sócio-política e, em consequência, da literária, de vários países da porção sul-americana, que, a partir de meados do século 20 foram vítimas de tomadas de poder por militares. Tais experiências promoveram inúmeras rasuras na vida de sujeitos, assim como aconteceu em Portugal, de modo que elas se manifestaram vividamente na obra de inúmeros poetas e ficcionistas, e não só, aqui e acolá, como foi o caso de Benedetti, como foi o caso de Jorge de Sena.

\footnotetext{
${ }_{9}$ Cf. O Reino da Estupider, de Jorge de Sena.

10 Tomado de empréstimo de Paul Ilie (1980), o insílio diz respeito ao “[...] exílio residencial, [...] de cunho sociológico, sofrido por parte do povo espanhol que ficou no país, em relação a esse vazio.” (Volpe, 2005, p. 80). Ainda a refletir sobre a situação latino-americana, mas que poderia caber para a situação de Jorge de Sena, resguardadas as possíveis diferenças contextuais, a autora comenta que o exílio interior " [...] poderia ser considerado uma forma de alienação em quase todos os sentidos que a palavra implica, pois o escritor vê essa atitude como a de quem está distante, apartado; estranho, estrangeiro; desconhecedor, desatento.” (Volpe, 2005, p. 82)

$11 \mathrm{O}$ desexílio diz respeito ao sentimento de vontade de regresso/retorno à terra natal, fundado pois na ambiguidade entre a necessidade de partir (provocada pelo fenômeno exílico) e um sentimento nostálgico de retorno. Vocábulo criado pelo próprio Mario Benedetti para dar conta da amplitude de sentidos que envolvem a experiência do exílio.
} 
Como poeta e lisboeta de berço, Jorge de Sena estaria miticamente mergulhado numa atmosfera que inspira a experiência do exílio desde sempre - por ser descendente de Ulisses, o fundador de Lisboa, e porque tradicionalmente o lugar dos poetas, na República platônica é fora da polis, da cidade, porque o discurso dos poetas e dos artistas inscreve-se no campo da aparência, não no do real. Daí que o sujeito deva sofrer as vicissitudes típicas que uma experiência de fratura incurável haveria de promover no íntimo de seu ser, como se percebe pela via de leitura aqui construída. Paralela a essa dimensão do ser do poeta, há a sua dimensão de intelectual português que haveria de refletir criticamente através de ensaios diversos e de sua intensa colaboração no jornal oposicionista Portugal Democrático ${ }^{12}$.

Ora, se a poesia de Jorge de Sena é marcada pela interferência da circunstancialidade que ata o acontecimento do poema às condições político-sociais e culturais e, por que não também espaço-temporais, que o enformam e dão a tônica de seu caráter profundamente ético, numa relação aproximativa entre o seu sujeito lírico e o outro, parece então que a experiência do exílio, esta "fratura incurável entre o ser humano e um lugar natal, entre o eu e seu verdadeiro lar [...]" (SAID, 2003, p. 46), marca que acompanha toda a sua vida desde o seu "estrangeiramento" em solo pátrio, forneceria importantes dados na leitura de poemas que carregam forte marca da paisagem que neles é construída.

Aliás, o poeta, por sua condição mesma, obriga a pensar a paisagem de uma maneira pouco convencional, na medida em que ele não se encontra num ponto de permanência estável, conhecida a sua condição de exilado, para vislumbrar a própria paisagem natal, nem mesmo as demais paisagens que aparecem em sua poesia. Seguindo a trilha poética seniana é que, portanto, esta dissertação tem como suporte teórico-metodológico os estudos acerca da paisagem sob uma perspectiva fenomenológica, promovida inicialmente por Eric Dardel, e que confluem nos estudos filosóficos de Michel Collot. Se a paisagem é alguma coisa que marca a obra seniana, cabe pensála, então, a partir da mobilidade espacial produto da situação exílica em que se encontra.

\footnotetext{
${ }_{12}$ Portugal Democrático foi um jornal de teor oposicionista ao regime de António de Oliveira Salazar, ditador português, que teve sua produção promovida por intelectuais portugueses que estavam em exílio, dentre eles Jorge de Sena. Sobre seus textos, Gilda Santos, em "Da arte de ser multiplamente português num exílio brasileiro" - texto escrito por ocasião do Colóquio em virtude dos 20 anos de falecimento do poeta, em 1998, e publicado em livro, junto de outros importantes escritos sobre a obra seniana, em 2001 - comenta, concordando com Eduardo Lourenço, da lacuna nos estudos senianos sobre a atuação política do poeta em solo brasileiro, em partes justificada "[...] no facto de Mécia de Sena não ter conseguido ainda um editor para a coletâcnea - já pronta - Textos de Intervenção Politica, obrigando o interessado à tarefa árdua de rastrear esses textos dispersos por vários veículos. Lacuna talvez alimentada pelo silêncio que o próprio autor lançou sobre esse veio da sua obra. Silêncio talvez motivado pelo duro aprendizado e longa prática em calar - que cedo Portugal the ensinara - quanto ao punível delito de pensar politicamente.” (SANTOS, G., 2001, p. 62)
} 
Dardel reelabora a concepção de espaço a partir do seu desmemembramento em espaços diversos, para melhor análise desta categoria geográfica. Dessa maneira, o francês aborda o surgimento dos espaços, bem como as representações simbólicas que deles se tem, a partir do postulado fenomenológico de ligação inseparável do homem com a Terra. O surgimento do espaço material, o espaço aquático, aéreo, o espaço construído e o próprio espaço geométrico são algumas das figurações do espaço físico de que fala Dardel, também responsável por cunhar o conceito de geograficidade, a própria condição de existência da realidade geográfica, “[...] suas ligações existenciais com a Terra, ou se preferirmos, sua geografia original: a Terra como lugar, base e meio de sua realização.” (DARDEL, 2011, p. 31). Aliás, é a partir do entendimento da Terra como base de sustentação do sujeito que Dardel depreenderá sua concepção de paisagem.

A paisagem passa a ser construção mediada pelos sentidos, sobretudo o da visão. Caso contrário, ela seria tão somente a justaposição de detalhes, de imagens e vivências que se esvairiam, não fosse a dimensão própria da visão de unificar ativamente as duas dimensões da experiência espacial: o sujeito que percebe e o espaço circundante. Posto que o geógrafo buscasse na fenomenologia a base de construção de seu conceito de geograficidade, é consequência decorrente disso, portanto, o fato de que o sujeito estabeleça com a paisagem uma relação de inseparabilidade, porque “[...] a paisagem não é, em sua essência, feita para se olhar, mas a inserção do homem no mundo, lugar de um combate pela vida, manifestação de seu ser com os outros, base de seu ser social.” (DARDEL, 2011, p. 32).

O sentido da visão parece ser aquilo que enlaça umbilicalmente o sujeito às paisagens que vivencia e que marcam fundo em sua geograficidade. Aqui a poesia seniana comunga de experiência semelhante, na medida em que é poesia tornada testemunho de linguagem. No bojo formativo do testemunho poético que Jorge de Sena engendra e elege como sendo sua poética, os sentidos passam a ter importância fundamental, porque é através deles que o sujeito consegue mediar as experiências com a terra infecta e com as paisagens, também elas infectas, para daí torna-las experiências estéticas no verso da página. É nesse sentido que Lourenço (2010) aponta para a fundamental importância dos sentidos, em especial o da visão e, em seguida, o da audição, na obra do poeta:

Se testemunhar é ver e, portanto, se o testemunho seniano é, principalmente, um testemunho de vista, ver, porém, significa mais do que ver apenas. Porque ver é um atributo da razão, ou como ficou dito, uma extensão do pensamento. Este ver o mundo, que é também, ou sobretudo, um pensar o mundo, indica claramente o papel da visão como instrumento ou órgão do testemunho poético; e de um testemunho que é meditação de mundo, [...]. Ver é, pois, verbo seniano. Obsessivo e obsediante, conduz toda a sua poesia, quase poema a poema. Ver, 
mas também olhar e contemplar, aparecem associados, não raro adquirindo a valência de outros sentidos. Assim, a visão e o olhar surgem como homólogos do desejo, do pensamento, e da fala. (LOURENÇO, J., 2010, p. 225-6)

$\mathrm{O}$ ato de ver a terra portuguesa, transformada em paisagem pelas mãos do poeta e vista em movimento - porque o sujeito está apartado da terra - na sua poesia, é, pois, refletir profundamente sobre um Portugal que representava tudo aquilo que o poeta mais rejeitava por sua formação humana e ética fundamental: ditadura, cerceamento das liberdades individuais, a erosão da possibilidade do tudo dizer a que o discurso deveria estar apenso. Em suma, um estado político que inibe a própria possibilidade de ser do poeta e do intelectual que fora. É, na via contrária, pensar o Portugal possível que se vislumbra nos anseios de uma "esperança desesperançada", imagem dialética tão presente no seu discurso poético.

As categorias de espaço, lugar e paisagem são, portanto, tópicos da ciência geográfica que se conectam pela via da experiência; aqui, uma experiência de fratura que não é meramente motivo de criação poética, mas algo que altera de modo profundo a visão que se terá da terra portuguesa e, por conseguinte, as terras de chegada, na medida em que a peregrinação infecta não se circunscreve somente à terra portuguesa.

Se se considera que espaço e lugar são categorias referentes ao modo pelo qual o homem vivencia uma determinada porção de terra - aqui entendida em sentido amplo, o que abre caminhos para entender esta terra como a casa da infância, e seus elementos interiores (o telhado, o sótão, os quartos e gavetas de cômoda; por fim, o porão), de onde partem as investigações fenomenológicoexistenciais de Gaston Bachelard, ou a casa habitada em situações diversas - como a casa americana do poeta. Tuan (2013) também analisaria as percepções com que são revestidos os sentimentos humanos em relação às múltiplas formações geográficas organizadas na paisagem.

Ambos, Eric Dardel Michel Collot, partem de pontos semelhantes para a análise dos temas que lhes ocuparam parte de suas vidas: a perspectiva experiencial ${ }^{13}$. Entender a tríade de conceitos

\footnotetext{
13 Tuan é pontual ao falar da experiência como elemento fundamental da vida humana, na medida em que é a partir da daquilo que se experiencia do mundo (para o bem ou para o mal), através dos sentidos de que dispomos, que obtemos conhecimentos para agir neste mesmo mundo. Isto fica claro na poética de Jorge de Sena, quando o poeta se serve dos sentidos do ver e do ouvir, que lhes são essenciais (como fica patente na leitura do poema "Os Trabalhos e Os Dias", encontrado em Coroa da Terra (1956) para a formulação de seu testemunho poético: como testemunho que se quer, o sujeito se põe em posição constante de expectação do mundo, para que dele extraia sua matéria poética, capaz de operar metamorfoses na ordem das coisas. Nesse sentido, o aporte teórico aqui utilizado e o objeto de estudo dialogam de maneira harmônica mais uma vez. A Tuan, portanto: "A experiência é um termo que abrange as diferentes maneiras por intermédio das quais uma pessoa conhece e constrói a realidade. Essas maneiras variam desde os sentidos mais diretos e passivos como o olfato, paladar e tato, até a percepção visual ativa e a maneira indireta de simbolização. [...] A experiência está voltada para o mundo exterior. Ver e pensar claramente vão além do eu.
} 
que aqui dispomos para a investigação da obra poética seniana envolve, num certo sentido, entender de que maneira tais conceitos são percebidos e organizados na mente humana, a partir dos sentidos, que exercem função plenamente ativa na estruturação dos sentimentos (positivos e/ou negativos) que o sujeito tem dos espaços e lugares (paisagem, por fim) que habita. E mais, de que maneira o "ver a paisagem" sofre as interferências de uma experiência exílica, uma vez que ela promove o deslocamento forçado de sujeitos para espaços outros distantes da terra natal.

Michel Collot (2010) desenvolve algumas reflexões acerca do entrelaçamento entre paisagem e poesia parte de três definições clássicas do termo encontradas em três dicionários franceses Robert: "Parte de um país que a natureza apresenta ao olho que a vê."; Larousse: "Extensão de um país que se pode abarcar em um conjunto" e a do Littré: "Extensão de um país que se vê de um só aspecto." - tais definições resguardam pontos de contato que lhes servem de base para explicitar suas (da paisagem) características: “[...] toda paisagem é percebida a partir de um ponto de vista único descobrindo, para o olhar, uma certa extensão, a qual corresponde apenas a uma parte do país em que se encontra o observador, mas que forma um conjunto imediatamente abarcável." (COLLOT, 2010, p. 205-6), que revelariam, portanto, o estabelecimento da paisagem no espaço do horizonte.

O ponto de vista diz respeito ao movimento de estruturação dos contornos da paisagem quando do momento de sua contemplação por alguém. Esta movimentação inscreve o espaço percebido num "não-horizonte", como aponta o francês, porque o horizonte surge como indício do elo fundamental (e fenomenologicamente sustentado) da aliança entre o eu expectador e o objeto expectado - o homem e paisagem, Jorge de Sena e Portugal. Desenha-se então um panorama no qual a possiblidade de habitação da paisagem, porque a paisagem é mais que tudo um momento de habitação, traduzirá algo na poesia seniana que diz respeito à presença inevitável da terra portuguesa na alma do de Sena.

Nesse sentido, o horizonte é aquilo que garante o pertencimento do sujeito ao território da paisagem, uma vez que ambos estão inseparavelmente interligados, numa relação em que ambos, mutualmente, agem e sofrem a ação promovida pelo sentido do olhar ativo e organizador. Aponta, Collot (2010), a partir do pensamento de Merleau-Ponty, que cita: "Sou eu que faço ser para mim [...] este horizonte cuja distância para mim desabaria, uma vez que ela não lhe pertence como uma propriedade, seu eu não estivesse lá para percorrê-la com o olhar.”14 (In: Collot, 2010, p. 206). O

A experiência tem uma conotação de passividade; a palavra sugere p que uma pessoa tem suportado ou sofrido. [...] Assim, a experiência implica a capacidade de aprender a partir da própria vivência. Experienciar é aprender; significa atuar sobre o dado e criar a partir dele." (TUAN, 2013, p. 17-18)

${ }^{14}$ Da nota de rodapé que acompanha a citação: Cf. Moles et Rohmer, Psychologie de l'espace, Castermann, 1978. 
olhar que aproxima de Merleau-Ponty é o mesmo que possibilita o distanciamento intencional na prática do testemunho seniano; um distanciamento que, ao fim e ao cabo, terá como finalidade objetiva o fornecer ao poeta condição necessária para, a partir da distância, enxergar melhor o Portugal que se inscreve em seu ser íntimo.

Fenomenologicamente corroída a separação existencial entre o sujeito e objeto do plano da perspectiva experiencial - movimento que se dá também na poesia seniana -, a paisagem, que já não mais é um lá para onde os olhos atentos de um expectador lançam um olhar distanciado, pode agora ser habitada, porque ela pertence ao sujeito e o sujeito à ela. Pertencimento este que se dá “A tal ponto que, às vezes, tenho a impressão de poder tocar o horizonte com um gesto da mão, tão facilmente que o abarco com o olhar." (Collot, 2010, p. 207), para concluir, em seguida, que "A paisagem é sentida como um prolongamento do espaço pessoal, [...]” (ibid, p. 207), e que, portanto, pode ser entendida como "espelho à afetividade", o que, de outra maneira, poderia ser dito que a paisagem reflete os sentimentos daquele que a abarca com o olhar. Não por acaso é que a investigação da paisagem na poesia de Jorge de Sena tenha que passar pelo exame da experiência exílica que surge como rastro fundamental na percepção da terra portuguesa.

A paisagem, porque tomada por um olhar atento, e por dedução, por um corpo de um sujeito situado no espaço, adquire duas características que lhes são fundamentais, para além do ponto de vista: 1) uma extensão que é inerente à plena realização dos sentidos humanos direcionados ao aprisionamento sensorial do espaço habitado e vivido; 2) a estruturação da paisagem por meio de uma porção, de uma parte, porque é a verticalidade do corpo que permite ao olhar perceber o horizonte como limite de união entre um eu e a paisagem. Nesse sentido, Collot (2010) é preciso, ao falar de uma dialética do visível e do invisível, no cerne do movimento do olhar em direção a paisagem:

Não sou um puro espírito, capaz de sobrevoar o mundo em uma visão perfeitamente panorâmica. Meu corpo me designa um lugar no próprio centro da paisagem que olho. É graças a ele que posso apreender "o campo", modificar meu ponto de vista. No entanto, é ele também que me liga ao aqui, impedindome de ver mais longe que lá [...] E ele não possui o dom da ubiquidade: ele só pode descobrir de uma só vez um "único aspecto" da paisagem. Todo ponto de vista é também um ponto de não visão, toda perspectiva exclui as outras: a paisagem é parcial porque é parcial. Meu corpo só me abre ao visível retirandome uma parte dele. [...]. (COLLOT, 2010, p. 209)

Por fim, cabe salientar o aspecto último da paisagem que diz respeito à sua capacidade de formar um conjunto: é porque não permite ser vista e abarcada por completo - a estrutura corporal que privilegia a verticalidade do corpo, com sua limitação espacial própria - que a paisagem forma 
um todo coerente: “[...] este não lugar que é o horizonte funda a coesão do lugar, faz dele uma paisagem, ou seja, um conjunto homogêneo.” (COLLOT, 2010, p. 213). É este conjunto da paisagem de Portugal, percebida a partir não de um espaço fixo como requer o caráter do ponto de vista, mas de pelo menos três outros espaços móveis e moventes, porque espaços que circunstanciam a experiência do afastamento da terra natal - Portugal, Brasil e Estados Unidos que interessa a esta dissertação. 


\section{ENSAIOS SOBRE A PEREGRINAÇÃO AOS LUGARES INFECTOS}

\section{1 - JORGE DE SENA E O MINOTAURO: AO DESTERRO, SEMPRE!}

\section{Da geograficidade ao dedo sujo "de investigar as origens da vida"}

O estudo da relação entre poesia e paisagem e o seu diálogo com a experiência do desterro na Peregrinatio ad Loca Infecta tem como ponto de partida, neste primeiro ensaio, o aparecimento textualmente grafado de um "dedo sujo", dado a meio percurso da trajetória poética de Jorge de Sena e a meio de seu diário infecto, de maneira precisa na seção brasileira. Esta imagem suja aparecida no biográfico "Em Creta, com o Minotauro"15 de 1965, ao mesmo tempo sintética e profusa, parece fornecer pistas seguras e interessantes para o desenvolvimento das reflexões que aqui tomarão forma.

Há, no poema narrativo, um movimento de impulso ao sentimento de irmandade entre o sujeito poético do testemunho, e o próprio Jorge de Sena, com a figura mítica do Minotauro, muito menos helênico, na percepção do poeta. Ambos haveriam de partilhar a mesma experiência pela via da trágica coincidência de terem sido seres em permanente estado de desterro: o poeta, estrangeirado em seu Portugal de nascença, o Minotauro, isolado de tudo e de todos, em seu labirinto. Restará Creta como destino último de uma peregrinação infecta, e de lá o poeta observará o mundo e a vida, enquanto mexe o seu café transnacional.

Percebe-se aí que o desterro foi tema de grande apreciação para Jorge de Sena, sobretudo quando se leva em consideração que esta experiência de fratura marca toda a sua vida e, por extensão, a sua obra poética, de que Peregrinatio ad Loca Infecta (1969) é importante modelo. É nela que se dá o aparecimento do "dedo sujo", tão fundamental imagem naquilo que ela carrega de rastro e abertura: a sujeira tornada objeto poético e estético é, no testemunho seniano, produto do ato investigativo em face às origens da vida. Nisso, o próprio café torna-se sujo, numa transferência através dos dedos já marcados.

Para o início deste ensaio, seria importante entender o conceito de desterro enquanto "fratura", cuja origem radica nos escritos em torno desta temática proposto por Edward Said, no

${ }^{15}$ Cf. Anexo C (poema na íntegra) 
livro Reflexões Sobre o Exílio e Outros Ensaios, na edição brasileira de 2003. O crítico já falecido, ali, afirma perigosamente que parte da cultura moderna do Ocidente seria produto das experiências de sujeitos exilados, emigrantes e refugiados. Tais categorias de fratura entre sujeito e terra podem ser semanticamente aproximadas, mas equivalem entre si, pelo fato de que implicam um nível de modulação do distanciamento, forçado ou não, do sujeito de um espaço geográfico delimitado.

Jorge de Sena em seu desterro triplo pode ser situado neste quadro sentimental de fraturas que marcaram o século 20. O crítico português Luís Adriano Carlos, acerca dos possíveis efeitos da experiência do exílio na obra do poeta, utilizou a seguinte gradação entre emigração e exílio, no que afirmou: "«Poucos poetas produziram como Jorge de Sena uma imagem tão viva e profunda dessa aventura grandiosa que é a Emigração - ou, na sua vertente mais amargurada, o Exílio.»" (CARLOS, L., 1983 ${ }^{16}$ ). Houve, na vida do poeta, a urgência de sair de Portugal e, pela via da amargura, a sua jornada torna-se exílio, desterro, que marca a sua obra.

O desterro pode ser, portanto, entendido como fratura incurável que decorre do afastamento forçado do sujeito de sua terra natal. Seria difícil mensurar o quanto da produção moderna é, de fato, produção de seres em estado descontínuo, mas o século 20 parece fornecer interessante pistas para pensar nas relações estabelecidas entre a experiência do desterro e a nacionalidade, ou o enraizamento. Se é difícil mensurar esses dados, é mais ou menos ponto pacífico a existência de uma produção literária intensa do que se convencionou chamar "Literatura de exílio", modo de escrita de seres em estado de deslocamento geográfico de suas terras, como o é a própria poesia de testemunho do português Jorge de Sena.

Dos produtos positivos e negativos gerados pela experiência do desterro, Edward Said assim reflete: “[...] embora seja verdade que a literatura e a história contêm episódios heróicos, românticos, gloriosos e até triunfais da vida de um exilado, eles não são mais do que esforços para superar a dor mutiladora da separação.” (SAID, 2003, p. 46). Portanto, esta experiência não pode ser vista senão por isto que é, de fato: fratura, e assim deve ser compreendida, ainda que possa produzir "positividades" em forma de obras admiráveis - a poesia circunstancial de Jorge de Sena - o crítico conclui: “As realizações do exílio são permanentemente minadas pela perda de algo deixado para trás para sempre” (SAID, 2003, p. 46).

Em Jorge de Sena, há algo que fica para trás, é verdade, mas ocorre também aquilo que Francisco Cota Fagundes assinala, em ensaio de 2001, como a ocorrência do desterro, na vida do poeta, em função da obra poética, como se ela em si obrigasse o poeta ao desterro:

${ }^{16}$ In: FAGUNDES, 2001, p. 51 
[...] com base em afirmações feitas por Octavio Paz em Las Peras del Olmo e na presença de dos temas atuais em questão, até mesmo na poesia anterior à partida do escritor para o Brasil, afirma o seguinte: «arrisco-me a propugnar que o exílio de Sena decorreu em grande parte de uma exigência da sua obra» (p. 254) (FAGUNDES, 2001, p. 52)

Do ponto de vista epistemológico, um produto positivo desta modernidade fraturada seria o pensamento de base fenomenológica em torno da concepção de paisagem, desenvolvido por uma nova corrente de geógrafos (humanistas) posicionados antagonicamente à postura matemático-científica dominante na ciência geográfica do início do século XX, cujos estudos pautavam-se no entendimento do espaço como elemento físico. Na esteira desse pensamento, a paisagem era entendida somente como espaço a ser visto ou contemplado, concepção originária daquela base cartesiana, a evidenciar uma cisão entre sujeito (elemento ativo) e objeto (elemento passivo), no plano da experiência. A cisão é, entretanto, anterior e advinda do próprio recorte metodológico cartesiano.

A cisão sujeito-objeto, de lastro cartesiano, foi fundamental para a Geografia, uma vez a partir dela nasce a inquietação entre geógrafos para repensar a ideia vigente de paisagem, e para o pensamento filosófico, modificado com o surgimento da Fenomenologia - corrente filosófica que tem em Kant seu precursor longínquo e em Edmund Husserl seu grande desenvolvedor - põe em questionamento a própria cisão sujeito-objeto. Em termos fenomenológicos, as coisas mesmas são postas entre parêntesis. Isto porque a ciência dos fenômenos parte do princípio de inseparabilidade entre as partes constituintes do processo de conhecimento e experiência que se dá na vida em ação, no mundo vivido. Tratava-se, pois, de um novo modo de entendimento da consciência e dos fenômenos que se lhe aparecem.

Nesse sentido, o postulado fenomenológico assentado no enunciado "Toda consciência é consciência de alguma coisa" ${ }^{\text {17 }}$ parece ser óbvio: se o sujeito tem consciência, parece natural que essa consciência deva ser de algo ou de alguma coisa - o substantivo parece cobrar esta complementação semântica sem a qual parece faltar algo. Contudo, a obviedade desaparece quando se entende que o que está em jogo é o estabelecimento de uma ligação incorruptível, via consciência, sujeito-objeto. É essa orientação fundamental norteadora de trabalhos como os de Merleau-Ponty

17 “Embora não possamos ter certeza da existência independente das coisas, diz Husserl, podemos estar certos da maneira pela qual as vemos de imediato na consciência, quer seja ilusória a coisa real que estamos vendo ou não. Os objetos podem ser considerados não como coisas em si, mas como coisas postuladas, ou "pretendidas", pela consciência. Toda consciência é consciência de alguma coisa. O ato de pensar e o objeto do pensamento estão internamente relacionados, são mutuamente dependentes.” (EAGLETON, 2003, p. 76) 
sobre a percepscão e a experiência, os de Gaston Bachelard e a sua poética do espaço, e o próprio pensamento geográfico de orientação humanista-cultural.

A Geografia Humanista e a Geografia Cultural - posteriormente, Geografia HumanistaCultural - toma para si o trabalho de colocar em revisão todos os temas geográficos a partir do referencial novo recém fundado. Levando em consideração o dado não-matemático na investigação da paisagem, os geógrafos incorporaram a dimensão humana e o elemento cultural em seus estudos sistemáticos. Com a inserção paulatina e parcial do saber dos fenômenos em suas análises, os geógrafos de orientação humanista passam a entender a paisagem como objeto intrinsecamente ligado ao sujeito. Sauer (1983), importante geógrafo no desenvolvimento da Geografia Cultural, já em 1925 propunha o estudo da paisagem a partir do aporte fenomenológico. Lê-se em Holzer (2008) o pensamento de Carl Sauer:

[...] o estudo das paisagens - conceito síntese da geografia - deveria iniciar-se com o estabelecimento de um sistema crítico delimitado pela fenomenologia da paisagem como método de estudo da relação entre o homem e o ambiente por ele formatado e transformado em habitat, em paisagem cultural. (SAUER, $1983)^{18}$

Para além de considerar um novo norte epistemológico para os estudos geográficos a partir de então, através da proposta de estabelecimento de um novo sistema investigativo para a Geografia que deveria passar obrigatoriamente pelas lentes da ciência fenomenológica, portanto, a inserção do elemento humano nas discussões em torno da paisagem, a proposta de Carl Sauer (1983) sinaliza para a relação interativa entre o homem e o espaço que o circunda, no sentido de que a paisagem cultural, um dos temas próprios da Geografia Cultural como ele aponta, estabelece uma relação dialógica de formatação e interferência mútua. Caberia ao geógrafo cultural, portanto, investigar as expressividades da presença humana inscritas no espaço. Contudo, não em qualquer espaço, mas numa área sua delimitada, que passaria a ser lida como área cultural.

Uma área cultural tem que ver com os recortes espaço-temporais que todo geógrafo cultural deverá realizar por meio “[...] de uma investigação sobre a distribuição passada e presente de características da cultura, que constitui a base para o reconhecimento e delimitação de áreas culturais" (WAGNER;MIKESELL, 1962) ${ }^{19}$. Nesse sentido, este tema torna-se de fundamental importância, posto que é o espaço com suas diversas e múltiplas configurações a condição mesma de realização de qualquer investigação geográfica, ao se considerar que toda a Geografia, independente de seus subcampos especializados, trata fundamentalmente da Terra. A área cultural

\footnotetext{
18 In: HOLZER, 2008, p. 137

${ }^{19}$ In: CORRÊA, 2010, p. 32
} 
demanda, pois, certa homogeneidade de formações culturais no espaço, que irão delimitar e definilo pela diferença, tornando-se aquilo que os geógrafos passam a dar o nome de paisagem cultural.

Tal qual cultura e área cultural, a paisagem cultural também é um tema da geografia cultural, e diz respeito a "[...] um artifício para distinguir e classificar regiões culturais [...]" $\left(\right.$ WAGNER;MIKESELL, 1962) ${ }^{20}$. Ora, parece então oportuno sinalizar para a intrínseca relação que a paisagem (cultural) mantém com a área cultural, na medida em que é a justa transformação de uma área cultural numa "região", caracterizada pela unidade interna de seus elementos constitutivos, que compõem o ideário de uma paisagem. Como bem apontam Wagner e Mikesell (1962):

A associação típica de características geográficas numa região ou em qualquer outra subdivisão espacial da superfície terrestre pode ser descrita como uma "paisagem". Este termo abrange tanto as características distintas que servem para diferenciar uma região, como as características que não se limitam a uma região determinada mas ocorrem nela. Então, a paisagem cultural refere-se ao conteúdo geográfico de uma determinada área ou a um complexo geográfico de um certo tipo, no qual são manifestas as escolhas feitas e as mudanças realizadas pelos homens enquanto membros de uma comunidade cultural. (WAGNER;MIKESELL, 1962) ${ }^{21}$

Se, como apontam Wagner e Mikesell (1962) acerca da funcionalidade da paisagem cultural na investigação geográfica de cunho humanista/cultural, quando afirma que: "[...] a geografia cultural seleciona para estudo as diferenças entre paisagens que não podem ser atribuídas a influências 'naturais' e as interferências do homem com o livre jogo dessas influências [...]" (idem, ibid), a paisagem cultural pensada dessa maneira funcionaria, portanto, como signo ou indício vivo das mudanças promovidas por grupos ou comunidades humanas num determinado espaço (área cultural transformada em região) e ao longo do tempo, de onde figura a importância da história da cultura $^{22}$ como tema que promove o resgate das constituições primitivas e passadas de paisagens, por meio da reunião de evidências, a fim de refletir acerca de suas sucessivas modificações. Para além dessa específica funcionalidade, o estudo da paisagem cultural ainda traria estas contribuições:

\footnotetext{
${ }^{20}$ In: CORRÊA, 2010, p. 34

${ }^{21}$ In: CORRÊA, 2010, p. 36

22 "A história da cultura, reunindo evidências, como foi descrito, a partir da distribuição de características e de complexos da biologia dos animais domesticados, da antropologia, linguística, topônimos, documentos, tradições orais e outras fontes, procura descobrir quatro tipos de fatos: a origem, no tempo e lugar, de determinadas características culturais; as rotas, épocas e modos de disseminação; a distribuição de áreas culturais anteriores; as características das paisagens culturais anteriores. Os problemas da história da cultura envolvem todo o tempo humano. [...] O historiador da cultura pode precisar de colaboração não apenas do arqueólogo e do paleolingüísta, mas de historiadores econômicos, agrônomos e etnólogos que lidam com fenômenos mais recentes." (WAGNER;MIKESELL, 1962 in CORRÊA, 2010, p. 42)
} 
[...] proporciona uma base para a classificação regional, possibilita um insight sobre o papel do homem nas transformações geográficas e esclarece certos aspectos da cultura e de comunidades culturais em si mesmas. [E ainda] Busca diferenças na paisagem que possam ser atribuídas a diferenças de conduta humana sob diferentes culturas e procura desvios de condições 'naturais' esperadas, causadas pelo homem.” (WAGNER;MIKESELL, 1962)23

Da perspectiva do tempo transcorrido entre os trabalhos de Carl Sauer e Eric Dardel - e, mais recentemente, Yi-Fu Tuan e Michel Collot -, os três primeiros sendo nomes fundamentais para o desenvolvimento da Geografia Humanista Cultural e muitos e diversos foram os estudiosos da paisagem, dentre arquitetos, filósofos, teóricos da literatura, psicólogos, que dedicariam trabalhos já sob influência de um olhar fenomenológico sobre as interações mútuas entre espaço e sujeito. Dardel, a exemplo, publica em 1953 o importante O Homem e a Terra, obra de profundo alcance no entendimento das relações que o homem estabelece com a Terra. A tradução para o português vem à lume somente em 2011, entretanto.

Mesmo sendo hoje uma obra indispensável para o pensamento acerca das diversas relações entre o homem e a Terra, ou seja, o espaço de realização da vida, espaço da vida em ação, O Homem e a Terra foi relegado ao esquecimento durante muito tempo, como relata Eduardo Marandola ${ }^{24}$, no prefácio que escreve à tradução brasileira, em partes pelo grau de inovação e vanguardismo ao tratar, o seu autor, de um modo radicalmente outro de um tema sobre o qual já se tinha toda uma clássica tradição de tratamento. Por sorte, os paradigmas hoje são outros e a importância da obra já é largamente reconhecida.

Dardel cunha o termo géographicité para falar da relação umbilical que o Homem estabelece com a Terra: “[...] amor ao solo natal ou busca por novos ambientes, uma relação concreta liga o homem à Terra, uma geograficidade (géographicité) do homem como modo de sua existência e de seu destino." (DARDEL, 2011, p. 2). Ou o enlace promovido pela paisagem e “[...] suas ligações existenciais com a Terra, ou se preferirmos, sua geografia original: a Terra como lugar, base e meio de sua realização." (DARDEL, 2011, p. 31). A Terra tornara-se, portanto, o meio pelo qual a realidade geográfica - logo, as vivências, experiências e percepções de mundo do sujeito - pode materialmente possível. Há algo de forte teor telúrico no pensamento dardeliano, se se pensa que

\footnotetext{
${ }^{23}$ In: CORRÊA, 2010, p. 36

24 “O Homem e a Terra é um típico caso de obra que estava muito à frente de seu tempo, o que resultou numa longa espera para que seus frutos pudessem aparecer. Esquecido durante décadas, mesmo na França, onde foi escrito e publicado (é visto como uma obra fora do contexto universitário geográfico da época, que por isso não produziu frutos imediatos), o livro, apesar de ter sido importante no início do projeto humanista da Geografia estadunidense nos anos de 1960 (há referências explícitas e implícitas nos trabalhos iniciais de Yi-Fu Tuan, Anne Buttimer e Edward Relph, pelo menos), teve sua difusão mais contundente com a publicação da tradução italiana em 1986." (MARANDOLA JR., 2011, p. 11 apud DARDEL, 2011)
} 
a Terra surge como espaço primeiro e original da vida humana; antes de qualquer relação que se tenha no espaço, a Terra.

É esta geograficidade pura - ou mesmo a ligação íntima do sujeito com lugar/espaço ${ }^{25}$, na perspectiva de Tuan - possível de se notada na poesia de Jorge de Sena e manifestada de modos diversos, mas sempre a se dar como resultado original de uma peregrinação infecta, que ao fim e ao cabo é toda a sua vida. A geograficidade parece levar o sujeito poético de "Em Creta, com o Minotauro" a chamar de "sujo" o dedo (dele) com que largamente investigou as origens da vida. Não por acaso, a postura investigativa é também um ato de perceber e de experienciar o mundo, porque pressupõe um modo pelo qual o poeta se relaciona com o que está a sua volta (paisagem/Terra), e um modo peculiar com o qual ele transforma, ou metamorfoseia, esta experimentação de mundo em matéria poética, culminando em seu testemunho poético.

O poema narrativo foi caracterizado por Francisco Cota Fagundes (2001) de poema-rio de "[...] de que numerosos textos de ficção e poesia senianos seriam como que afluentes" (FAGUNDES, 2001, p. 58). Seria um poema de uma dimensão dúplice: catalisadora, porque nele convergem temas fundamentais e perenes da obra seniana; e difusora, porque se conecta e promove poemas outros que parecem ser extensão sua. Ou mesmo, é poema fundamental na poética do testemunho por tornar escrito, portanto, metamorfoseado em testemunho, aquilo que aparece desde cedo nos escritos senianos, mas que não tem nome, aquela específica sujeira de "investigar as origens da vida”. Assim como a sua própria poética, surgida desde seus primeiros escritos, mas teorizada somente aquando do prefácio da coletânea Poesia-I, o mesmo parece ocorrer com o sintagma dedo sujo.

Do poema-rio à obra seniana, Jorge Fazenda Lourenço (2010) aponta para a poesia o seu caráter redivivo e referencial de poder retomar sempre um outro poema seu ou de outro poeta, criando uma teia poética feita de diálogo. Ora, ambos, Fagundes e Lourenço, chamam a atenção para aquilo que há de fundamental no testemunho seniano: o seu caráter dialogante, a revelar a dimensão da experiência humana, tornada ela mesma numa eterna e profícua peregrinação, ou a passagem do voyeur ao voyant, como analisa Lourenço, J. (2010), materializada na imagem telúrica do dedo sujo. Mesmo porque, apesar de sua inscrição grafada ser de 1965, a sujeira poética se faz

\footnotetext{
25 “'Espaço' e 'lugar' são termos familiares que indicam experiências comuns. Vivemos no espaço [...] O lugar é segurança e o espaço é liberdade: estamos ligados ao primeiro e desejamos o outro. Não há lugar como o lar. O que é lar? É a velha casa, o velho bairro, a velha cidade ou a pátria. Na experiência, o significado de espaço frequentemente se funde com o de lugar [...] As ideias de "espaço" e "lugar" não podem ser definidas uma sem a outra." (TUAN, 2013, p. 11-14)
} 
indício e mesmo rastro fulcral desde o início da obra do poeta, sendo por isso o elemento de diálogo entre os poemas que aqui serão analisados.

O dedo sujo de Jorge de Sena engendra um movimento de abertura que tem caráter dúplice na medida em que estabelece uma conexão com o Portugal histórico de Camões, a partir da citação dos versos do clássico português, mas não só, e com um futuro que pode ser o Portugal "inefável”, adjetivo que Sena usa de modo extremamente crítico a sinalizar não para sua apreensão figurada mas para o estado de impossibilidade de expressão do discurso poético livre das amarras de censura impostas pelo regime salazarista. Uma inefabilidade sentida já do período de 1950, época da escritura de "Paraísos Artificiais"; e, se assim o é, melhor que seja um futuro em Creta, junto do Minotauro, lugar onde a inefabilidade do dizer tudo aquilo que deve ser dito em relação ao que ocorre em torno do poeta não é condição de vida.

Deste Portugal que aparece no narrativo autobiográfico como espaço de pertencimento pátrio do poeta, ainda que posto em questão pela via da identidade apresentada como “[...] camisas [que] se despem, / se usam e se deitam fora, como todo o respeito / necessário à roupa que se veste e que prestou serviço [...]”, há uma outra descrição, temporalmente anterior, mas que resguarda questões similares. Falo do poema "Os paraísos artificiais", cuja aparição se dá na abertura da seção intitulada I - Circunstância, do livro Pedra Filosofal (1950). Aqui Portugal aparecerá como terra precedida do possessivo (minha); portanto, como pertencimento umbilical que permitirá ao poeta apontar mesmo aquilo que há, mas sobretudo aquilo que não há em sua terra.

De fato, o poema é antecedido por uma epígrafe goethiana a indicar o caráter fundamental da poesia de Jorge de Sena: a concepção de ser a poesia essencialmente circunstancial, ou como ilumina um de seus prefácios confessionais, onde o poeta se explica e teoriza, simultaneamente, em seu anti-prefácio, na coletânea Poesia-III, quando escreve que "Toda a poesia é circunstancial; e a específica circunstancialidade dela será precisamente o que contribui para a particular unidade desta Peregrinatio: [...]”. E, acrescentaria, de toda a sua obra poética, na medida em que as epígrafes não devem ser menosprezadas na leitura da poesia seniana, como já apontou Lourenço, J. (2010). De mais a mais, Goethe é-lhe fundamental também pela tópica da circunstancialidade, a ele:

O mundo é tão grande e tão rico, e a vida tão cheia de variedade, que nunca faltarão motivações para poemas. Mão hão-de ser sempre poemas circunstanciais, quer dizer, a realidade terá de proporcionar-lhes o motivo e a matéria. (Goethe em «Conversações de Goethe com Eckermann» 18 de Setembro de 1823) ${ }^{26}$

${ }^{26}$ In: SENA, 2013, p. 145 
A evocar o caráter idílico inerente a um certo discurso proferido em relação à Terra de nascença, o poema põe em questão, já de início, duas possibilidades de entendimento da terra: de princípio, o sujeito lírico nos fala de sua terra precedida pelo indicador espacial (na) e o possessivo (minha). "Na minha terra", entendida como Portugal, é o solo pátrio de que se fala; logo em seguida o sujeito constata dois fatos, um decorrente do outro: “[...] não há terra, há ruas;”. Da primeira terra, que surge com evocação do espaço pátrio, logo, como estabelecimento da localização geográfica de onde emana a geograficidade do poema, aparece uma "terra" entendida como chão, firmeza do solo, que simplesmente não há, num Portugal cada vez mais penetrado pelo asfaltamento de suas ruas e verticalização de sua paisagem.

Este sujeito lírico, constituído numa espécie de biografema, está a falar de seu Portugal natal, e nisso aproxima-se do canto golçalvino, e só. Porque o cântico seniano é de outra ordem, na medida em que é feito e fecundado pela percepção de uma ausência quase agônica. O Portugal que canta é aquele marcado pela ausência de tudo aquilo que um dia houve, e hoje já não há. É, portanto, um cântico sem música: como o vaso da China, cuja queda interrompe o instante de audição da peça de Debussy, parecer ser este poema surgido do mesmo instante em que se percebe que, do vaso, saem papéis velhos e sujeira. Talvez seja o seu caráter (não)exaltativo o lugar de potência testemunhal deste poema, que expande os sentidos do dizer, ao revelar, pelo anti-cântico, um Portugal que toda a gente se empenha em ignorar, como já apontava na sua carta-poema ${ }^{27}$, "Carta aos meus filhos sobre os fuzilamentos de Goya ${ }^{28 ”, ~ d e ~ M e t a m o r f o s e s ~(1963) . ~}$

\footnotetext{
${ }^{27}$ Do mesmo período do genesíaco "«La Cathedrale engloutie», de Debussy", cujo referente é a peça debussiana, na carta-poema o referente desloca-se para a pintura. De fato, a partir do vislumbre do quadro "Três de Maio", de Francisco de Goya, Jorge de Sena parte para a escrita de um de seus poemas mais pungentes, na expressão de um testemunho paciente e desesperado acerca não só do evento específico que tocou o coração daquele pintor: um fragmento doloroso dos horrores do período em que a Espanha foi tomada pelas forças de Napoleão Bonaparte, e que toca o coração do poeta português.
}

Cf. Anexo B.

${ }^{28}$ Francisco José de Goya y Lucientes, ou somente Goya: pintor espanhol da cidade de Fuendetodos. Sua produção artística se circunscreve ao período do final do século XVIII e começo do XIX. Uma produção que se inscreve, portanto, entre o reinado de Charles III, rei que instaura uma monarquia iluminista em Espanha, e o período de dominação napoleônica em território espanhol. De vasta produção artística, Goya pintou quadros de personalidades da monarquia espanhola e francesa - aquando da tomada de Espanha por Napoleão Bonaparte - a quadros que retratam os horrores da guerra entre espanhóis e franceses para retomada do trono daquele país da península ibérica. The Second of May e The Third of May, ambos de 1808 e encontrados no Museo del Prado (Madrid), retratam, o primeiro: o levante popular do povo espanhol contra soldados franceses; o segundo: civis espanhóis sendo encurralados e executados por soldados do exército napoleônico. É este segundo quadro, o "Três de Maio", que inspira as meditações poéticas que são prosaicamente encadeadas em "Carta aos meus filhos sobre os fuzilamentos de Goya".

The Second of May (1808): «https://www.museodelprado.es/en/the-collection/art-work/the-2nd-of-may-1808-inmadrid-or-the-fight/57dacf2e-5d10-4ded-85aa-9ff6f741f6b1»

The Third of May (1808): «https://www.museodelprado.es/en/the-collection/art-work/the-3rd-of-may-1808-inmadrid-or-the-executions/5e177409-2993-4240-97fb-847a02c6496c» 


\section{De fendas e fissuras: Jorge de Sena e a consciência poética}

O surgimento deste sujeito poético à maneira de biografema pode ser localizado em sua poesia na escritura de sua catedral aquática e sonora, num livro que compreenderia ao segundo bloco de produção poética de Jorge Sena, na esteira do enquadramento proposto por Morna (1985); na sua Arte de Música (1968), portanto. Procedo, agora, a este poema, a fim de esclarecer a constituição do sujeito poético do testemunho e a consciência poética diferenciada, a ele atrelado.

A construção do poema genesíaco "«La Cathedrale Engloutie», de Debussy”" engendrada numa cadência de tom prosaico, posto parecer se tratar de um relato poético, apresenta uma dimensão anti-sonora, e explico o porquê adiante, oferece ao leitor uma experiência sensorial rica e profusa: os acordes debussianos levam o poeta à construção do poema, pela urgência da escrita testemunhal, ainda que isso só venha a acontecer anos depois da audição primeira, no rádio Pilot da avó do poeta. Ou antes, os mesmos acordes instauram certa paralisia do sujeito diante da página em branco, que toma contornos e forma de versos somente com o rompante, imagético e sonoro, promovido pelo instante da queda do vaso chinês, ornato de onde saem papéis velhos e desimportantes, julga o sujeito.

Somente aí, neste momento que é a poesia emerge como consciência outra, nova de tudo aquilo que era feito antes. Neste momento, ele mesmo constituído de uma anti-música, posto ser ruído percebido pelo leitor, na estratégia proposta na estrutura do poema, a poesia aparece em meio a uma cadeia de gradação iniciada pelos acordes, mas que transita pelo ruído e pela sujeira empenhada pelos papéis velhos contidos no vaso e chega à imagem, ou mesmo ao poema, enquanto testemunho feito de linguagem. A imagem, neste poema, é em si mesma sonora, basta que se atente para a composição dos versos no instante em que ocorre a queda seguida do estilhaçamento completo daquele vaso chinês. A poesia seniana disso é feita.

Mas se falo do surgimento de uma consciência poética em Jorge de Sena a partir de um poema que somente lhe surge e aparece em sua obra no ano de 1964, especificamente em Arte de Música (1968), é porque nele há o caráter genesíaco que importa bastante. Como o seu "dedo sujo", é como se o poema estivesse sendo formado no ser do poeta ao longo de anos, desde a audição primeira da peça de debussiana, até explodir em versos sonoros e aquáticos na sua "«La Cathédrale Engloutie», de Debussy"; e isso justifica o fato de que, se não trago um poema de Perseguição (1942), primeira obra de Sena, é por entender que a essencial importância deste poema de 1964 aglutina

${ }^{29}$ Cf. Anexo A (poema na íntegra). 
um conjuntos de elementos facilmente identificáveis na poética seniana, sobre os quais falo a seguir: o testemunho como forma especialmente aceita para a criação poética e as implicações que daí decorrem, uma notável.

Ora, o processo de surgimento de uma consciência poética ou o seu despertar para ela, que somente surgido em forma de poema e, portanto, como teoria poética, marca da poesia do século $\mathrm{XX}$ - o aparecimento do poema também como teoria de que fala Octavio $\mathrm{Paz}^{30}$-- neste poema de $1964^{31}$ portanto, posterior à formação de seus primeiros poemas, é o mesmo que ocorre com o sintagma "dedo sujo", que somente aparece, textualmente grafado, no clássico "Em Creta...", em Peregrinatio, de 1969, mas que pode ser sentido bem antes da formação daquele poema, como se em alusão a uma certa postura surrealista, forte em Jorge de Sena e que se aproxima do abjeccionismo imagético.

O aparecimento do testemunho em poesia implica no surgimento de um sujeito poético novo, um sujeito que partilha com o eu biográfico algumas semelhanças. O sujeito poético de Jorge de Sena, ao se afirmar como sujeito de testemunho, promove um movimento de duplo afastamento em relação aos dois grandes modos pelos quais se constituiu a lírica portuguesa até o século XX: afasta-se de um sujeito essencialmente confessional e pré-moderno - o sujeito que se espraia por meio de seus versos; mas também afasta-se da experiência heteronímica promovida por Fernando Pessoa, de onde se apreende, à maneira de Jorge de Sena, que "as virtualidades são maiores que os continentes". Afastamentos que devem ser entendidos no quadro dialético que é a formação intelectual (e poética) seniana. Nesse sentido, a poética de Jorge de Sena revela-se como espaço

\footnotetext{
${ }^{30}$ A poesia moderna é também teoria de poesia, postula Octavio Paz, numa reflexão em que o poeta mexicano explana a evolução da recepção crítica de poesia ao longo da história - de sua remota apreciação original à sua gradual perda de importância, acentuada pelo advento da burguesia enquanto classe econômica e política que substitui o lugar da então decadente aristocracia. Disso advém, pois, a decadência da poesia, na medida em que esta não importa à burguesia. Nesse sentido, em Portugal, na esteira da modernidade crítica que inaugura a poesia com, também, teoria de poesia, Jorge de Sena em sua poética não escapa a esse intento modernista, de que dão notícias diversos poemas: “[...] Com a mesma decisão do pensamento filosófico, a poesia tenta assentar a palavra poética no próprio homem. O poeta não vê suas imagens a revelação de um poder estranho. Ao contrário das sagradas Escrituras, a escrita poética é a revelação de si mesmo que o homem faz a si mesmo. Dessa circunstância decorre o fato de que a poesia moderna também é teoria da poesia. Movido pela necessidade de fundamentar sua atividade em princípios que a filosofia lhe recusa e a teologia só lhe concede em parte, o poeta se desdobra em crítico. ." (PAZ, 2012, pp. 241-242). Sobre esta questão, aliás, a leitura de A função poético-crítica em Jorge de Sena: problemáticas do poema moderno dissertação de mestrado apresentada ao Programa de Pós-Graduação em Letras (Literatura Portuguesa) da FFLCHUSP, em 2009, de autoria de Danilo Bueno Rodrigues - joga luz a várias questões importantes.

31 Seria enganoso considerar que somente em “"La Cathedrale Egloutie», de Debussy" encontra-se a primeira formulação poética sobre a poética do testemunho, ou sobre o surgimento da consciência poética para Jorge de Sena. Com efeito, já em Perseguição (1942), seu primeiro livro, o poema "Leprosaria" (citado no segundo ensaio desta dissertação) dá alguma notícia da rejeição de uma certa poesia feita àquele período. O poema apresenta, nesse sentido, alguma orientação poética para a poética do testemunho, ainda que não fique clara a alternativa do poeta frente ao estado das artes que denuncia. Já nos Cadernos de Poesia, do qual foi editor, são notáveis as páginas de orientação estética e programática, de onde o lema "A Poesia é só uma!" é reivindicação claramente de Jorge de Sena, hoje se sabe.
} 
intervalar, como se se encontrasse num espaço de intermédio das duas experiências poéticas que lhe antecedem - confissão e fingimento - situando-se num lugar, a usar um termo do próprio poeta, de entre-distância de onde o afastamento é a exata medida de sua aproximação.

O próprio termo, testemunho, implica, simultaneamente, vestígio e declaração, presentificação de algo que transcende a linguagem pela mesma linguagem ou, como dirá mais tarde Jorge de Sena, «a poesia como criação de linguagem é suprareal, isto é, engloba a realidade e a sua mesma representação linguística». Apenas o faz através de um elemento catalisador, filtro e motor do processo, que é o sujeito. O sujeito da lírica seniana vive na posição incómoda de toda a testemunha: revelando, deixando passar através de si a realidade, toda a realidade, sofre um apagamento extremo; mas, por outro lado, oferecendo-se como lugar de uma voz, torna-se a face dessa mesma voz, revelando-se ao revelar. Daí que o perfil de um $e u$ enquanto poeta seja muito perceptível e se chegue a erigir em verdadeira vocação. (MORNA, 1985, p. 25)

O sujeito da lírica seniana estaria assim constituído pelo apagamento do si-mesmo, porque revela a tudo e a todos - todas as realidades possíveis - simultâneo a um igual desvelamento de simesmo, porque nesse processo ficam à mostra as suas escolhas e opções próprias por aquilo que revela e ou encobre. Ora, e o que se percebe no poema musical que encena o surgimento da poesia na vida de Jorge de Sena, senão a exata percepção de um sujeito que é ele mesmo Jorge de Sena, a contar da audição da peça debussiana e como tal fato marca sua experiência humana de tal modo que ele jamais pode ser o mesmo, pode jamais ser o poeta de uma consciência testemunhal da vida?

O testemunho implica ou estaria ligado a duas práticas que lhes são fundamentais: a percepção do mundo, através dos sentidos humanos, relacionada aos vestígios possíveis de serem tateados neste mundo infecto; e, por outro lado, o impulso ético que destina este sujeito poético à declaração, via criação estética e de linguagem - a própria poesia em seu processo formativo - dos vestígios vistos, ouvidos e tateados pelo mundo afora. Nesse processo, altamente fenomenológico, de onde se observa a viva ligação do sujeito com o mundo circundante, não me parece que, como pontua Morna (1985), o sujeito sofra um apagamento; antes, a poesia seniana é um retorno profundo do sujeito ao texto poético, dada sua funcionalidade "catalisadora" e organizadora daqueles vestígios (ou vivências). O eu pulsa no poema seniano juntamente com a realidade que não lhe é nunca menos pulsante.

Ou seja, a poesia seniana é vestígio e declaração e um além, feito de sua predestinação a uma ética que torna a declaração escrita o próprio testemunho com função transformadora.

Nesta chave, o poema sinaliza em sua primeira estrofe para o aparecimento dum "eu" afirmativo ou mesmo judicativo a falar de sua relação fundamental com a música, marcada pelo não-perdão, atitude fundamental na constituição do poema. Há aí uma atitude que, posteriormente 
e a par da trajetória poética de Jorge de Sena, revela-se dupla: o sujeito tem na música o fio que o conduziu à literatura, à poesia. De certo, o poeta era já leitor àquela época, leitor voraz, os versos não negam - "Eu lia muito, é certo. Lera / o Ponson du Terrail, o Campos Júnior, o Verne e o Salgari, / o Eça e o Pascoaes." além de caderninhos em francês para aperfeiçoamento do idioma mas a música lhe desperta para uma consciência poética nova, um sentimento novo de relação com as artes, sobretudo com a poesia, que irá moldar a sua consciência poética de maneira permanente, daí o não perdão de que fala no primeiro verso.

A música era também grande paixão seniana, fato de que dão conta diversos testemunhos ${ }^{32}$ do poeta, de colegas seus - Cleonice Berardinelli fala, por exemplo, da paixão por tocar piano que movia a ambos -, e não à toa a criação em sua obra de poemas meditativos que partem fundamentalmente de peças musicais clássicas, o Arte de Música. Portanto, não é aleatória ou despropositada a aparição de Viúva Alegre e de Mozart neste poema; muito menos o é a aparição de Claude Debussy ${ }^{33}$, cuja peça musical, inspiradora do poema sobre o qual estas linhas tecem breve leitura $^{34}$, evocam através de seus acordes e ajustamentos a própria cidade de Ys, a cidade mítica submersa.

A audição da peça de Debussy no rádio Pilot da avó de Jorge de Sena é, pois, reveladora: dela, da audição dos acordes aquáticos (pensativos e trêmulos) que emergem da catedral submersa ocorre o despertar, no ser do poeta, para a percepção de certas "fendas" "que na vida, / na minha e na dos outros, ou havia ou faltavam.”. O som da peça musical abre ao poeta o vislumbre da imagem da catedral, que no poema é já uma transfiguração que potencializa a consciência então

\footnotetext{
${ }^{32}$ Da importância da música na vida de Jorge de Sena, Cf:: "Não sendo músico (cedo me aposentei de veleidades activas, nesse sentido), a música tem, para mim, uma importância decisiva. Posso passar sem ler ou sem ver artes plásticas, mas não posso passar sem ouvir música. Sou capaz de ouvir repetidamente uma peça que me interesse ou fascine, como não suporto ler repetidamente um mesmo poema, a não ser em doses muito homeopáticas." (SENA, 1968b, p. 180-181) O excerto encontra-se em acordo com a hipótese desenvolvida na dissertação de mestrado em Letras Vernáculas de Sebastião Edson Sousa Macedo - As metamorfoses do sujeito em Arte de Música apresentada à UFRJ em 2009. Ali o crítico investiga a possibilidade de ser a música vetor de metamorfoses na poesia seniana, a partir de um poema que julga ser central e que aqui recupero, "«La Cathédrale engloutie», de Debussy".

33 Claude Debussy escreve a peça que inspira o poema de Jorge de Sena em 1910. Certamente dentro da corrente de influencias promovida pela divulgação de uma edição mais ou menos ajustada da história da cidade de Ys, pelas mãos de Villemarqué. Até 1839, a bela lenda bretã circulava e era conhecida apenas oralmente; dali em diante, a cidade e seu mito passam a circular em muitas outras obras, sendo Preludes (1910), de Debussy, uma delas. E o poema de Jorge de Sena, que da peça debussiana se serve (ou é servido) e reatualiza, como efeito colateral, o mito bretão em si mesmo.

${ }^{34}$ De certo, há estudos mais detidos sobre este poema de Jorge de Sena, sobretudo os que se encontram na tese de doutoramento em Letras Vernáculas de Luciana dos Santos Salles, apresentada à UFRJ em 2009. Em Poesia e o diabo a quatro: Jorge de Sena e a escrita do diálogo, a estudiosa empreende um estudo da obra de Jorge de Sena a partir de suas múltiplas relações construídas com outras formas de manifestação da arte. Escultura, pintura, música e outros textos são, portanto, o outro eixo comparativo de análise que se encontra naquela tese. As considerações que faz Luciana Salles (2009) sobre "«La Cathédrale Engloutie», de Debussy" e o movimento de integração entre poesia e música na obra de Jorge de Sena, uma poesia que se escreveu sempre por meio do diálogo - o título da tese prenuncia - são interessantíssimas.
} 
nascente das fendas e fissuras, elementos tão fundamentais a um sujeito fraturado pela experiência de exílio, posto ser o desterro sempre uma "fratura incurável", e que o acompanham, pois, por toda a vida.

O elemento água é transmutado em acorde, por isso são tão audíveis em sua peça, e é desse efeito que surge mentalmente ao poeta a imagem da "Catedral" (espaço mítico). Ora, Debussy mostra ao poeta a Catedral de Ys, e o poeta a presentifica em meio a uma atualização própria em seus versos. Por meio de recorrência de imagens como "sinos", "abóbadas", "cânticos", "altas torres" e paro aqui, o poeta deixa antever a primazia da audição e da visão, sentidos a ele fundamentais, porque captam a experiência percebida no poema.

Os sentidos da visão e da audição tem sido identificados como sentidos essenciais da poética do testemunho, a tornar os verbos ver e ouvir verbos especialmente senianos, na percepção de Lourenço (2010). É a operação eficaz no funcionamento destes sentidos, ou seja, a possibilidade que neles há de captar sensorialmente a experiência, de que se serve o poeta do testemunho. Dessa operação, via transmutação da experiência, nasce o poema, ele mesmo já um elemento transmutado (linguagem) cuja função deve ser a de promover, nos sujeitos, uma abertura à percepção daquela visão profunda de que o poema nos fala; visão profunda que é uma das marcas da poesia seniana e que se encontra de maneira fundamental em Peregrinatio ad Loca Infecta.

Contudo, a operação de transmutação de experiências - boas ou ruins, o sujeito assume o compromisso de testemunhar - em objeto estético (poema) não se dá de maneira tranquila, sobretudo porque, no caso de Jorge de Sena, o que se revela como processo final estará sempre naquela esfera das "fissuras da vida" que afirmam o compromisso do poeta com o dever poético, com a ética e ao homem, num ato de fidelidade que, bem ou mal, é de uma grandeza indiscutível. Se a música lhe serviu como ensinamento e educação poética, porque depois de Debussy, jamais pode o poeta ser o mesmo - ele testemunha, com a força do "não-perdão" - sua poesia é metamorfose, é mudança, ou ao menos anseio, daí a evocação da imagem do "vaso da China".

Ante um caderno, tentei dizer tudo isso. Mas só a música que comprei e estudei ao piano mo ensinou mas sem palavras. Escrevi. Como o vaso da China, pomposo e com dragões em relevo, que havia na sala, e que uma criada ao espanejar partiu, e dele saíram lixo e papéis velhos lá caídos, as fissuras da vida abriram-se-me para sempre, ainda que o sentido de muitas eu só entendesse mais tarde.

(SENA, 2013, p. 385-7) 
Um vaso que se quebra no momento em que a música cessa, ou a música cessa exatamente pela queda do vaso. Há aqui uma fenda promovida pelo deslocamento, na tessitura do poema, do plano auditivo (sonoro) ao plano visual (imagético). Não se trata de uma oposição ou transição rígida, na medida em que, pode-se perceber, o que há de sonoro nos versos do poema acaba por evocar imagens aquaticamente precisas; do outro lado, o que nele há de imagético suscita a sonoridade. Portanto, é do barulho da queda do vaso, um ruído, uma anti-música, que surge o despertar da consciência poética em Jorge de Sena.

Ora, é neste momento (ou seria um espaço?) de operação quase alquímica - de transmutação do vivido em objeto estético de linguagem - em que se encontra e aparece o sujeito do testemunho poético. Também, no exato momento da forja da personalidade poética de Jorge de Sena. É aí que ocorre aquilo que é precioso no poeta das Metamorfoses: a transformação do sujeito instaurado num "eu-mesmo" individualizado ao "eu do testemunho" - um eu profundamente compromissado, caracterizado no poema como exigência, anseio e dúvida, porque, afinal, ser uma testemunha dá ao sujeito uma posição que longe está de ser confortável, na medida em que se empenha a evidenciar aos demais sempre aquela "visão profunda", não a que fingem, mas a que recusam.

Ou seja, cabe ao poeta desvelar os véus que cobrem os olhos daqueles que se recusam a ver quão injusto e catastrófico é o mundo que os cerca, um mundo infecto de que dão clara notícia alguns dos versos mais elaborados de seu diário infecto, Peregrinatio. Da música ao poema, o poeta nos dá conta do aparecimento de sua consciência poética, compromissada desde sempre a testemunhar esta "desgraça impotente de actuar no mundo"; uma impotência que não impede o ato, entretanto. “La Cathédrale Engloutie», de Debussy” encerra seus versos com o recurso da pergunta pareada, facilmente identificável na poesia de Sena. Assim lhe surgiu a poesia, bem como o seu dedo sujo.

\section{Regresso aos "Paraísos Artificiais": Portugal e Creta}

Tendo visto o nascimento de uma consciência poética calcada no papel fundamental do testemunho, passo agora à análise de poemas que são afluentes de seu poema-rio, onde podem ser vistos Jorge de Sena e o Minotauro, a tomar café. Passo aos seus paraísos, não menos artificiais: 


\section{OS PARAÍSOS ARTIFICIAIS}

Na minha terra, não há terra, há ruas;

Mesmo as colinas são de prédios altos

Com renda muito mais alta.

$\mathrm{Na}$ minha terra, não há árvores nem flores.

As flores, tão escassas, dos jardins mudam ao mês,

E a Câmara tem máquinas especialíssimas para desenraizar

[as árvores.

O cântico das aves - não há cânticos,

Mas só canários de 3.o andar e papagaios de 5.o.

E a música do vento é frio nos pardieiros.

$\mathrm{Na}$ minha terra, porém, não há pardieiros, Que são todos na Pérsia ou na China,

Ou em países inefáveis.

A minha terra não é inefável.

A vida na minha terra é que é inefável.

Inefável é o que não pode ser dito.

$3 / 5 / 1947$

(SENA, 2013, p. 147)

Construído como paródia, ou contracanto, a "Canção do Exílio", de Gonçalves Dias, que apresenta uma terra idílica cheia de positividades pela apresentação da Natureza efervescente encontrada na terra do poeta maranhense, "Paraísos Artificiais" apresenta uma imagem de Portugal figurada pela negativa e marcada pela forte presença da estrutura "não há", em oposição clara ao "tem" golçalvino que marca a presença dos atributos naturais belos de sua terra, ao passo que destaca certa ausência, ou antes, menoridade, na medida em que o "tem” de Gonçalves Dias é sempre seguido de um "mais", que é certamente decisivo no sentimento do poeta em querer vislumbrar uma vez mais, pedido que roga à Deus, aquelas paisagens, destes mesmos atributos na terra em que se encontra à época da feitura do poema; coincidentemente, o mesmo Portugal de Sena.

Ora, se no Portugal da época de Gonçalves Dias, há “terra”, “árvores”, "flores”, ainda que comparativamente inferior, o que é lógico, posto ser o poema de um tom profundamente idílico e exortativo das belezas brasileiras (ou maranhenses), no Portugal de Jorge de Sena, a natureza é marcada por um contínuo "não há", que segue do começo ao fim do poema: "Na minha terra, não há terra, há ruas; [...], não há árvores nem flores. [... O cântico das aves - não há cânticos, [...] não 
há pardieiros, [...]” e desemboca em sua estrofe final que aponta para uma outra questão fundamental na poesia seniana: a possibilidade do dizer, do testemunhar.

O sujeito lírico sinaliza num jogo de linguagem que é próprio da poética do testemunho as condições de vida de um Portugal aplacado pela ditadura salazarista, que censura tudo o que é de opinião adversa à sua estrutura. Na impossibilidade de dizer, de escrever e, portanto, de agir, porque a escrita seniana é também, ou idealmente pretende ser, um modo de agir e transformar o mundo pela via da denúncia das injustiças e desmandos do mundo, um papel que Jorge de Sena assume duplamente para si: enquanto poeta que entende ser a poesia um modo de transformação do mundo e enquanto intelectual português que sempre foi; na impossibilidade de tudo isso é que o poeta conclui que viver em Portugal traduz-se em impossibilidade, porque tiram-lhe e a todos os demais portugueses certa condição básica do viver: a liberdade de expressão. Nesse sentido, se em países inefáveis pode-se encontrar pardieiros, mas não em Portugal; em Creta, quem sabe?

O poema põe em questão, lida a partir de sua estrofe última, o próprio fazer poético enquanto possibilidade se realização do si-mesmo, estratégia que, aliás, aparecerá adiante no narrativo "Em Creta, com o Minotauro", quando o espaço de escrita do próprio poema surge ao sujeito como possibilidade de existência e abrigo diante das atrocidades presenciadas por sua peregrinação. A escrita seniana é, também, espaço de liberdade do sujeito que se vê preso na dinâmica da ditadura imposta pelo novo regime português, porque é o espaço onde tudo pode ser dito, ainda que este dizer passe pelo crivo do Estado, como ocorreu na publicação de As Evidências (1955). De acordo com Lage (2010), em seu estudo sobre a questão da cidadania e do regime salazarista por meio da obra de Jorge de Sena, lê-se:

Das entrelinhas do neo-realismo à sobrelinha seniana, a literatura é o espaço de tudo dizer que dinamita o censurado. É um exílio literário, neste sentido também exigido pela necessidade de tudo dizer, adentrado, porque se faz na e pela língua; aliás, o exílio é de que tudo se diga na língua censurada cá dentro. A notícia que chega é a da própria língua na expressão de tudo dizer. (LAGE, 2010, p. 25)

Nesse sentido, aí reside um dos fundamentos da ética na poesia seniana, que não se cala diante do estado ditatorial, posto que é seu compromisso estar vinculada ao seu tempo histórico e a sua inerente circunstancialidade, propulsor de criação da matéria poética, como se verifica num poema-síntese dos fundamentos de sua poética, "Os Trabalhos e Os Dias" de 1942, publicado em Coroa da Terra (1946). A começar pela comparação presente no primeiro verso (mesa $=$ mundo), o eu-lírico seniano, que é sempre constituído numa relação aproximada com o sujeito empírico/biográfico, quase se imiscuindo a ele, Jorge de Sena atribui à escrita (poética) a característica de vitalidade, o que implica diretamente no caráter ético de sua poesia. 
Ou como apontou Jorge Fernandes da Silveira em ensaio acerca da poesia de Jorge de Sena: "O poeta, sentado à mesa a escrever é a consciência em progresso da hipótese amorosa, intelectual, temporal, social, mágica, de que 'à medida que' escreve 'o mundo inteiro', os objetos da cultura material e estética que o formam, tudo enfim, cabem no microcosmo de um poema." (SILVEIRA, 2003 , p. 263). Escrever equivale a respirar, condição que produz uma ligação umbilical entre o sujeito e o mundo; ou, no conjunto imagético do poema, o eu-lírico e a mesa, ligados por uma corrente que é o próprio compromisso ético do poeta com o mundo que o circunda, posto que "não há outro possível":

\section{OS TRABALHOS E OS DIAS}

Sento-me à mesa como se a mesa fosse o mundo inteiro e principio a escrever como se escrever fosse respirar o amor que não se esvai enquanto os corpos sabem de um caminho sem nada para o regresso da vida.

À medida que escrevo, vou ficando espantado com a convicção que a mínima coisa põe em não ser nada. $\mathrm{Na}$ mínima coisa que sou, pôde a poesia ser hábito. Vem, teimosa, com a alegria de eu ficar alegre, quando fico triste por serem palavras já ditas estas que vêm, lembradas, doutros poemas velhos.

Uma corrente me prende à mesa em que os homens comem.

$\mathrm{E}$ os convivas que chegam intencionalmente sorriem e só eu sei porque principiei a escrever no princípio do mundo e desenhei uma rena para a caçar melhor e falo da verdade, essa iguaria rara: este papel, esta mesa, eu apreendendo o que escrevo.

$27 / 10 / 1942$

(SENA, 2013, p. 88)

Este poema, aliás, dialoga com um anterior seu, "Quem a tem...”, de 1956, onde o poeta há de denunciar de modo muito claro a situação de aprisionamento em que vive o Portugal salazarista que se impõe como via única de vida ao sujeito. Numa estrofe inicial reveladora de um profundo sentimento de esperança na humanidade e no movimento de mudança próprio da História, o sujeito lírico afirma que "Não hei-de morrer sem saber / qual a cor da liberdade.". Tais versos inscrevem-se em duas realidades distintas: a) a realidade de censura que vive a terra portuguesa no período de produção do poema; evocada pela segunda realidade b) a presentificação de um futuro pautado na certeza de que a liberdade há-de chegar, cedo ou tarde. 


\section{«QUEM A TEM...»}

Não hei-de morrer sem saber qual a cor da liberdade.

Eu não posso senão ser desta terra em que nasci. Embora ao mundo pertença e sempre a verdade vença, qual será ser livre aqui, não hei-de morrer sem saber.

Trocaram tudo em maldade, é quase um crime viver. Mas, embora escondam tudo e me queiram cego e mudo, não hei-de morrer sem saber qual a cor da liberdade. 9/12/1956

(SENA, 2013, p. 254-5)

O poeta, a exemplo daquilo que realiza na construção de "Paraísos Artificiais", no estabelecimento da terra enquanto pátria e enquanto firmeza do chão, aqui postula certo grau de pertencimento nacionalista, ancorado na impossibilidade de, sendo português, não poder ser outra coisa que não português, ainda que parta a viver em outros espaços de exílio, na ânsia de viver plena liberdade, como, de fato, ocorrerá em sua vida, duplamente, a coroar sua peregrinação infecta. O pertencimento a uma pátria específica, visto sempre com certo grau de distanciamento e reserva por Jorge de Sena, é que torna plena a consciência de que, apesar de cidadão do mundo, ele é e sempre será português.

Ora, ser cidadão do mundo, para além do óbvio estabelecimento da relação do poeta com o espaço que o circunda e que é muito mais amplo que Portugal, remeterá ao próprio compromisso ético que o poeta assume ao prender-se à “[...] mesa em que os homens comem”, a ver e escutar o movimento da vida. Justamente por isso, a luta pela liberdade é tão importante, caso contrário a vida traduz-se numa própria impossibilidade de testemunho, que culmina na mudez e na surdez do poeta. O poeta, ainda em 1956, ansiava pelo fim do regime salazarista, que só virá a ocorrer 18 anos depois, quando irrompe no dia 25 de abril de 1974 a Revolução dos Cravos, instaurando a tão sonhada liberdade portuguesa de que tanto falam os versos senianos e tantos outros intelectuais portugueses que lutaram pelo fim da ditadura salazarista. 
Jorge de Sena formula a sua poética do testemunho não como teoria apriorística ou como coisa intelectualmente pensada desde o início de sua atividade poética. O primeiro registro de teorização desta poética ocorre de modo condensado no prefácio da primeira edição da coletânea Poesia-I (1961). Isto significa que o testemunho poético seniano é, antes mesmo de ser um guia de construção de poemas, uma prática poética ${ }^{35}$ que acompanha o poeta desde o início de sua vida literária. Testemunhar em poesia implica viver e experienciar o mundo posto com aquela mesma intensidade e vigilância atenta com que vive o Minotauro, na ilha de Creta, e com o qual o poeta, ou melhor, o sujeito lírico que ali e ao longo de toda a poesia seniana muito se aproxima do sujeito empírico, tanto se identifica, a ponto de espelhar a sua vida com a dele.

A decisão de optar pela criação de um sujeito poético que escreve versos que parecem muito mais dizer, ou mesmo narrar, da vida do próprio português, engenheiro e pai de filhos brasileiros, "quando lá estiver", é a demonstração da consciência que Jorge de Sena tem de recusar o princípio central da poética de seu precursor, Fernando Pessoa, ou suplantar alguma coisa que falta ao fingimento pessoano, como aponta Fátima Freitas Morna: "Toda a poética de Jorge de Sena se submeteria assim a uma teoria do testemunbo como forma alternativa e dialecticamente complementar do "fingimento poético"' (MORNA, 1985, p. 24). Para o poeta, entretanto, a poesia deve ter um papel ético, por isso transformador, o que não comporta o uso de máscaras tais quais aquelas usadas no fingimento pessoano. A diferença reside no fato de que, no poema seniano, o sujeito lírico não é o Minotauro, e nem deseja sê-lo, porque suas vidas estão espelhadas; fosse um poema pessoano, o sujeito seria ele mesmo a figura mítica em si.

Poema encontrado em sua Peregrinatio Ad Loca Infecta (1969), que figura como diário poético da circunstacialidade maior que se abateu à vida de Jorge de Sena a partir de 1959: o desterro. É nessa data que o poeta, a convite de brasileiros, vem proferir uma conferência no $4^{\circ}$ Colóquio de Estudos Luso-Brasileiros, na Universidade da Bahia (Adolfo Casais Monteiro e Eduardo Lourenço, amigos de Sena, também participaram do colóquio), e no Brasil já fica a viver o que seria o seu primeiro exílio - ou segundo, caso se considere que a situação de medo e restrição na qual vivia a sociedade portuguesa sob o jugo da ditadura salazarista impele o poeta, que fora sempre um crítico ferrenho do regime ditatorial, a um certo autodesterro em solo pátrio. Tal hipótese do autodesterro

\footnotetext{
35 “[...] a formulação do testemunho poético não é uma construção apriorística, no sentido de uma teoria que comande a prática poética, como no caso, por exemplo, do neo-realismo, condicionado, a partida, por uma ideologia política e partidária. [...] A teoria do testemunho surge, assim, como a validação de uma prática poética em progresso; ou melhor, como uma práxis que naquele Prefácio de 1960 se organiza enquanto dádiva de uma consciência criadora, que, no acto de aferir-se, se revela." (LOURENÇO, J., 2010, p. 105)
} 
como afastamento primeiro de sua pátria encontra suporte na própria constituição de Peregrinatio, que recolhe poemas desde o ano de 1950, ano em que o poeta ainda vivia em Portugal.

A paisagem de que aqui se fala é entendida naquela mesma apreensão que realiza Michel Collot em suas reflexões sobre a poesia. Cada porção de terra que aparece no narrativo autobiográfico seniano é uma paisagem que se apresenta ao sujeito como imagem selecionada por um ponto de vista peculiar e específico, o que evidencia a participação ativa do sujeito na aparição da paisagem que surge como extensão inalcançável em seu todo, por isso, o sujeito tem apenas a visão de sua parte, que constitui um todo. Portugal, Brasil, Estados Unidos e Creta assim surgirão na poesia seniana.

O poema-rio é estruturalmente construído em cinco partes que narram uma trajetória simultaneamente específica, porque vinculada a circunstancialidade dos desterros do poeta, e universal, porque o sujeito lírico transcende o sujeito biográfico, sem de modo algum implodir a ponte de ligação que os une. O percurso narrado no poema ocorre através da peregrinação do poeta por entre espaços nos quais viveu entre 1959 e 1978: a) Portugal, desterro adentrado b) Brasil, segundo desterro, onde o poeta viveu entre os anos de 1959-65, iniciou sua carreira acadêmica e foi “[...] pai de brasileiros no Brasil”; c) Estados Unidos da América, a lembrar de que este poema é de 1965, último ano do poeta em solo brasileiro. E um último espaço: d) Creta, lugar possível onde o poeta há-de irmanar-se com o Minotauro, para com ele tomar café.

I

Nascido em Portugal, de pais portugueses, e pai de brasileiros no Brasil, serei talvez norte-americano quando lá estiver.

Coleccionarei nacionalidades como camisas se despem, se usam e se deitam fora, com todo o respeito necessário à roupa que se veste e que prestou serviço. Eu sou eu mesmo a minha pátria. A pátria de que escrevo é a língua em que por acaso de gerações nasci. E a do que faço e de que vivo é esta raiva que tenho de pouca humanidade neste mundo quando não acredito em outro, e só outro quereria que este mesmo fosse. Mas, se um dia me esquecer de tudo, espero envelhecer tomando café em Creta com o Minotauro, sob o olhar de deuses sem vergonha.

O engenheiro Sena, na voz de seu sujeito lírico, ou talvez o oposto, põe em suspenso a percepção natural com que se enxerga o fenômeno de pertencimento a uma pátria. Seguindo a ideia do poema, nascer em um espaço determinado ao qual se convencionou chamar "pátria" é um mero acaso, e de fato o é. O sentimento de pertença a uma pátria é um dado construído, não inato, por 
isso o poeta questiona tanto e entende com muita desconfiança o fenômeno da nacionalidade. Não por acaso, as primeiras estrofes do poema evocam uma questão própria em Jorge de Sena que é a da identidade relacionada a um espaço geográfico específico (Portugal, Brasil ou Estados Unidos) para desembocar numa sugestão de pátria que se inscreve no espaço da escrita poética; da língua, portanto.

Feito isso, o sujeito parece desvincular-se de qualquer tipo de pátria específica, espaço social, cultural e, sobretudo, geograficamente delimitado, para afirmar, talvez numa alusão a Bernardo Soares, cuja pátria é a língua portuguesa, que ele mesmo é a sua própria pátria; o sujeito torna-se lugar de si mesmo, bem como torna a escrita e a língua com que escreve, a portuguesa outro lugar possível de realização do si-mesmo. Entre estes dois lugares de afetividades positivas e negativas, o Eu e a língua, há um pacto ético de fidelidade que se cumpre através do testemunho sincero daquilo tudo de "Quem muito viu, sofreu, passou trabalhos, / mágoas, humilhações, tristes surpresas; [...] / e andou terras e gentes, conheceu os mundos e submundos; [...]" (SENA, 2013, p. 485-6), que é a poesia do poeta desterrado, que “[...] será sempre sem pátria. [...]” (SENA, 2013, p. 485-6).

É importante prestar atenção aos versos 4-6 da primeira parte do poema: “Coleccionarei nacionalidades como camisas se despem, / se usam e se deitam fora, com todo o respeito / necessário à roupa que se veste e que prestou serviço.”, pois são versos que expõem a desconfiança do sujeito face ao fenômeno da nacionalidade, mesmo porque ele tem muita consciência de sua relação intrínseca com as experiências de fratura. De todo modo, o próprio exílio de Jorge de Sena deve-se a uma questão de nacionalidade, posto que o poeta-engenheiro era ferrenho opositor da ditadura salazarista. Ainda sobre a relação nacionalismo-exílio, Edward Said é esclarecedor:

Chegamos ao nacionalismo e sua associação essencial ao exílio. O nacionalismo é uma declaração de pertencer a um lugar, a um povo, a uma herança cultural. Ele afirma uma pátria criada por uma comunidade de língua, cultura e de costumes e, ao fazê-lo, rechaça o exílio, luta para evitar seus estragos. Com efeito, a interação entre nacionalismo e exílio é como a dialética hegeliana do senhor e do escravo, opostos que informam e constituem um ao outro. Em seus primeiros estágios, todos os nacionalismos se desenvolvem a partir de uma situação de separação. (SAID, 2003, p. 49)

O fim da primeira estrofe do poema apresenta já a figura do Minotauro como elemento mítico que deverá ser ombreado, ou melhor, espelhado, com a figura do poeta Jorge de Sena e de seu sujeito lírico. Daí que, se na primeira estrofe do poema leem-se versos que dão conta de uma biografia do sujeito lírico hiper aproximada da de seu sujeito biográfico, a estrofe segunda é toda tomada pela escritura da biografia do Minotauro, esta figura mítica que é “[...] metade boi e metade homem, como todos os homens.". O poeta humaniza o homem-animal mito, de modo que quase 
chegamos a ouvir sua voz a ecoar por entre os contornos do labirinto no qual fora posto, como ocorre na recriação mítica escrita pelo argentino Jorge Luis Borges no conto "A casa de Astérion"36 , e dá sentido à sua (do Minotauro) experiência própria que, assim como a do poeta, é a experiência de fratura e desterro.

II

O Minotauro compreender-me-á.

Tem cornos, como os sábios e os inimigos da vida.

É metade boi e metade homem, como todos os homens.

Violava e devorava virgens, como todas as bestas.

Filho de Pasifaë, foi irmão de um verso de Racine, que Valéry, o cretino, achava um dos mais belos da "langue".

Irmão também de Ariadne, embrulharam-no num novelo de que [se lixou.

Teseu, o herói, e, como todos os gregos heróicos, um filho

riu-lhe no focinho respeitável.

[da puta,

O Minotauro compreender-me-á, tomará café comigo, enquanto

o sol serenamente desce sobre o mar, e as sombras,

cheias de ninfas e de efebos desempregados,

se cerrarão dulcíssimas nas chávenas,

como o açúcar que mexeremos com o dedo sujo

de investigar as origens da vida.

O Minotauro compreenderá o poeta porque ambos partilham de experiências similares que fortalecem o espelhamento que o poema propõe, ainda que seja, nas palavras da pesquisadora Luciana Salles, um “espelhamento enigmático e distorcido”, muito diferente, aliás, do que ocorre na poesia de seu precursor, Fernando Pessoa e na do movimento romântico. Se no "drama em gente", as sensações do mundo são experimentadas por pessoas outras, radicalmente diferentes do sujeito empírico, posto também como "pessoa" outra; aqui, e em toda a poesia de Jorge de Sena, o sujeito lírico apresenta-se irmanado com o sujeito empírico, porque compartilham as mesmas dores e vivências. De fato, um espelhamento, que aqui figura distorcido, mas noutros poemas muito nítido:

Por um espelho enigmático e distorcido mas, ainda assim, espelho, o poeta vai traçando através da biografia do amigo Minotauro, pela citação e pela simetria, sua própria vida: exilado em labirintos como o Minotauro, "metade boi e metade homem" como o Minotauro e "todos os homens", sábio e inimigo da vida como todas as bestas, recluso em poesia como o "filho de Pasifaë, irmão de um verso de Racine". Aos poucos, a descrição da figura mitológica e a auto-apresentação

\footnotetext{
${ }^{36} \mathrm{O}$ conto no qual ocorre a humanização da figura mítica do Minotauro, "A casa de Astérion", pode ser encontrado livro clássico de Jorge Luis Borges $O$ Aleph, em publicação de 2008, pela Companhia das Letras e tradução de Davi Arrigucci Jr.
} 
("Nascido em Portugal, de pais portugueses / e pai de brasileiros no Brasil"...) vão se entrelaçando num único texto que, ambivalente, funciona como um poema, singular, de biografias, no plural. Unidas pelo diálogo, as figuras híbridas de um poeta português/brasileiro/norte-americano e de uma criatura "metade boi e metade homem" tornam-se impossíveis reflexos um do outro, tão diferentes quanto podem ser escritor e besta mitológica, próximos como personagem e autor que se faz também personagem de si mesmo, irmanados pela escritura a ponto de se converterem em potenciais metáforas um do outro. $(\text { SALLES, s/d. s/p) })^{37}$

É curioso pensar, como orienta a leitura, que dos espaços de exílio que flutuam na construção do poema, uma infinidade de lugares que formam uma cartografia do desterro que vai de Portugal até o Brasil, segue para os Estados Unidos, retorna à Europa brevemente e desemboca em Creta e no universo grego, apenas a figura do poeta e a do Minotauro são as que sobram apesar de tudo e de todos. Os deuses? Hão-de observá-los placidamente, como se estivessem apenas a contemplar a paisagem que se abre sob seus olhos. Teseu, o herói grego? "Um filho da puta", assim como os demais heróis gregos. As ninfas e os efebos? Desempregados. Restam, então, essas duas figuras fraturadas, nessa paisagem em desespero, a tomar café, adoçado pelo "dedo sujo" do poeta, em suas chávenas que contém pura investigação das origens da vida.

Desta existência fraturada que se dá num espelhamento entre o poeta e o Minotauro - e, portanto, já se pode aqui aventar a hipótese de um espelhamento triplo, posto que, na tessitura de seu testemunho o sujeito biográfico é espelhado no sujeito lírico, e é essa figura dupla/tripla que se re/espelha com a figura mítica -, desse processo estético-formal, por isso mesmo, ético, deriva a flutuação temporal do poema, que se dá na evocação do passado, do presente e a projeção dum futuro possível. Jorge de Sena expressa um desejo claro no verso primeiro da terceira estrofe: “[...] reencontrar-me de ter deixado/ a vida pelo mundo em pedaços repartida, [...]”, desejo que só pode ser realizado num espaço de exílio, em Creta. Aliás, esses são versos que remontam à poesia de Camões, também português e também exilado, “[...] aquele pobre diabo que o Minotauro não leu, porque / como toda a gente, não sabe português.”.

III

É aí que eu quero reencontrar-me de ter deixado

a vida pelo mundo em pedaços repartida, como dizia

aquele pobre diabo que o Minotauro não leu, porque,

\footnotetext{
37 O ensaio completo, de autoria da Profa. Dra. Luciana dos Santos Salles, consta do site "Ler Jorge de Sena”, portal abrigado por pesquisadores da obra de Jorge de Sena da Universidade Federal do Rio de Janeiro (UFRJ), reunindo farto material acerca da biografia, obra e fortuna crítica do poeta português. Segue link para o texto: «http://www.lerjorgedesena.letras.ufrj.br/ressonancias/pesquisa/ufrj/18-biografias-de-um-minotauro-jorge-de-senae-a-vida-que-escreve-a-si-mesma/». O texto, contudo, fora originalmente publicado em: Biografias de um Minotauro: Jorge de Sena e a vida que se escreve a si mesma. In: Paula Morão; Carina Infante do Carmo. (Org.). Escrever a Vida: Verdade e Ficção. 1ed. Lisboa: Campo das Letras, 2008, p. 339-3.
} 
como toda a gente, não sabe português.

Também eu não sei grego, segundo as mais seguras

Conversaremos em volapuque, já [informações.

que nenhum de nós o sabe. O Minotauro

não falava grego, não era grego, viveu antes da Grécia,

de toda esta merda douta que nos cobre há séculos,

cagada pelos nossos escravos, ou por nós quando somos

os escravos de outros. Ao café,

diremos um ao outro as nossas mágoas.

Tal qual o Minotauro, que não sabe português e, por isso, não leu a tradição literária portuguesa, representada na figura do poeta Camões, o sujeito lírico admite não saber grego, motivo pelo qual não haveria comunicação possível entre estas duas figuras espelhadas que não pelo intermédio de uma terceira linguagem que se torna comum aos dois, o Volapuque: “[...] Conversaremos em volapuque, já / que nenhum de nós o sabe. [...]”, demandando aprendizado mútuo e simultâneo. Luciana Salles (s/d), em ensaio já aqui comentado, aventa sobre esse verso a hipótese de que o estabelecimento de uma língua nova, mediadora da comunicação entre ambos, implica um esforço de abandono da língua portuguesa, no caso do poeta, e, portanto, de toda a carga cultural, de toda a tradição que ela carrega:

Depois de haver declarado já na primeira estrofe do poema: "Eu sou eu mesmo a minha pátria. A pátria / de que escrevo é a língua em que por acaso de gerações /nasci.", o poeta decide abrir mão dessa língua recebida "por acaso", em nome de uma nova língua que, por não pertencer a ninguém, pode permitir uma comunicação absolutamente nova, livre da carga "de toda esta merda douta que nos cobre há séculos, /cagada pelos nossos escravos, ou por nós quando somos / os escravos de outros." Em volapuque ${ }^{38}$, idioma perfeito porque perfeitamente ignorado, toda a liberdade é possível, sem heranças e sem restrições préestabelecidas, sem conceitos ou signos arbitrários - a língua ideal, portanto, para alguém que deseja uma "vida reclusa em poesia". (SALLES, s/d, s/p)

Ora, o poeta se coloca no início do poema como respeitável colecionador de nacionalidades, o que parece garantir a sustentação da hipótese de que, mesmo adotando o volapuque como nova língua e toda carga cultural que este novo idioma venha a ter futuramente, à medida que o poeta e o Minotauro interajam, o português ainda deve permanecer enquanto memória que preserva a vida que nele se escreve, de onde o "respeito" pela camisa (nacionalidade) que se despe. Nesse sentido, ainda que a língua antiga do poeta seja coberta desta “[...] merda douta que nos cobre há séculos, / cagada pelos nossos escravos, ou por nós quando somos / os escravos

\footnotetext{
${ }^{38}$ Nota de rodapé explicativa, de autoria da Profa. Dra. Luciana Salles, cuja referência já foi dada em citação anterior do mesmo texto: "Talvez o "volapuque" seja a língua em que Sena escreve seus "Sonetos a Afrodite Anadiómena", grupo de poemas que encerra, à guisa de apêndice, o volume das Metamorfoses e no qual o poeta, declaradamente, tenta romper com a lógica habitual de significação em busca de uma linguagem não arbitrária mas orgânica, que poderia ser a música, ou mesmo o silêncio."
} 
de outros.”, dispensá-la seria dispensar a carga de experiências que a circunda, bem como sua importância para a construção de sua própria poética; seria de pronto rejeitar sua condição própria de "colecionador de nacionalidades".

Jorge de Sena congrega em seu projeto poético um grande arranjo de tradição e modernidade. Daquela, o português sem dúvida foi grande leitor, não tendo sido por acaso que Camões foi um dos poetas que ocupou muito de sua atenção, quer do ponto de vista acadêmico Sena defendeu sua tese de doutoramento em Luiz Vaz de Camões e dedicou vários ensaios sobre este autor - quer do ponto de vista da própria tessitura de sua poesia - sendo o longo poema "Camões dirige-se a seus contemporâneos" um exemplo de diálogo intertextual no nível da biografia do poeta clássico, e mesmo "Em Creta, com O minotauro", que evoca a tradição camoniana em versos quase que literalmente transcritos.

Da lírica clássica, da tradição, Jorge de Sena aprende a ideia própria de Lírica e a constituição do sujeito poético: aquele que é um outro que não o próprio sujeito empírico, eis talvez a mais básica lição da constituição da lírica. Ocorre que, aliado a esse ensinamento, o poeta pensa na necessidade de este mesmo sujeito lírico ser um sujeito preocupado e atento à sua volta, à paisagem, na acepção moderna de que se falou anteriormente. Para isso, o poeta atualiza a função poética do sujeito lírico; um sujeito que se serve fartamente das experiências fornecidas pela peregrinação infecta que empreende o sujeito empírico, tornando próximas as relações entre a voz que fala no poema e o sujeito biográfico que atende pelo nome Jorge de Sena.

Constitui-se assim o testemunho poético e a lição de des/afeto e de paisagem da poesia de Jorge de Sena: na aproximação mesma do sujeito lírico com o sujeito empírico quase ao nível da fusão deste naquele por completo, capaz de formar uma poesia de qualidade formal e estética e sensível ao mundo com o qual ela mantém íntima relação de dependência. Uma poesia, portanto, profundamente ética e sensível às circunstancias que envolvem a sua produção, porque mesmo que "Em Creta, com o Minotauro, / sem versos e sem vida, / sem pátrias e sem espírito, / sem nada, nem ninguém, / que não o dedo sujo, / hei-de tomar em paz o meu café." ainda sim restará o “dedo sujo" como ponte de ligação fundamental entre um Eu, que é lírico e biográfico, logo, toda a gente, e o mundo enquanto espaço possível de realização da vida humana.

Fica claro, a partir dos poemas aqui analisados, que algumas hipóteses de trabalho que constavam do pré-projeto de pesquisa já não mais se sustentam: na poesia de Jorge de Sena, Portugal não figura como lugar, naquela acepção de conforto e segurança proposta por Tuan (2012); é a própria paisagem, que exige do sujeito empírico (ou lírico) o olhar a partir de um ponto de vista atuante e modificador que enxerga a porção do espaço, porque a paisagem nunca se mostra em sua 
totalidade e, mesmo, assim, porque a visão é sentido estruturante, forma um conjunto, traduzido, no caso de Portugal, como impossibilidade do dizer da vida e das circunstancias que afligem o país tudo o que deve ser dito, a não ser pelo espaço da escrita.

Quanto aos espaços de desterro diferentes do próprio Portugal (espaço onde o poeta se sente estrangeirado), Brasil e Estados Unidos, estes figuram como territórios que possibilitam ao poeta o exercício de tudo dizer, livre da censura salazarista ou de qualquer outro regime totalitarista. Nesse sentido, também não se configuram como lugares, e seria ingênuo ou até forçoso querer que assim os fossem considerados. São igualmente paisagens, iguais a Portugal, mas que desempenham funções distintas daquela, como será visto nos outros dois ensaios.

O poeta ao longo de sua vida construiu uma obra multifacetada que dialoga com a tradição portuguesa e universal, em poesia, modificando-a e inserindo novos elementos, num esforço de abrir novas viseiras sobre o fazer poético. O testemunho poético, manifestação própria de seu labor artístico, a surgir como opção estético-formal inovadora, e sobretudo ética, ao uso de máscaras do fingimento pessoano (visto por ele como esteticismo absoluto) e ao surgimento de um neorrealismo (que decalca a vida social sem a preocupação estética que a obra literária demanda), é ele mesmo uma poética que congrega, a um só tempo, o rigor estético e a visão de mundo profunda que tem o poeta da paisagem que o circunda.

Octavio Paz, ao iniciar suas reflexões sobre o fazer poético na modernidade, em seu clássico O Arco e a Lira, percorre rapidamente por algumas concepções já dadas sobre o que é a poesia. Ali, em um paragrafo, o crítico e poeta mexicano percorre os caminhos do ser da poesia através de su ainvestigação sobre os diálogos e tensões entre modernidade e tradição. Interessa, aqui, sobretudo a associação que faz o crítico entre poesia e conhecimento, ou entre poesia e salvação, ou seja, a poesia enquanto ato capaz de mudar o mundo. Interessa porque, a despeito de imprimir à poesia (e as demais artes, talvez) um peso e uma missão que talvez não sejam a dela, propriamente, alinhase a uma concepção muito própria à metamorfose de Jorge de Sena. Ao Paz:

A poesia é conhecimento, salvação, poder, abandono. Operação capaz de mudar o mundo, a atividade poética é revolucionária por natureza; exercício espiritual, é um método de libertação interior. A poesia revela este mundo; cria outro. Pão dos escolhidos; alimento maldito. Isola; une. Convite à viagem; retorno à terra natal. Inspiração, respiração, exercício muscular. Prece ao vazio, diálogo com a ausência: o tédio, a angústia e o desespero a alimentam. Oração, ladainha, epifania, presença. Exorcismo, conjuro, magia. Sublimação, compensação, condensação do inconsciente. Expressão histórica de raças, nações, classes. [...] Pura e impura, sagrada e maldita, popular e minoritária, coletiva e pessoal, nua e vestida, falada, pintada, escrita, ostenta todos os rostos mas há quem afirma que não possui nenhum: o poema é uma máscara que oculta o vazio, bela prova da 
supérflua grandeza de toda obra humana! (PAZ, 2012, p. 21)

Cabe nesta descrição que faz Octavio Paz sobre o fazer poético a concepção de testemunho proposta e executada por Jorge de Sena ao longo de toda a sua produção poética? Para o poeta português, assim como na síntese descritiva do crítico mexicano, a poesia é, de algum modo, "conhecimento", adquirido por meio das experiências e vivências que o sujeito empírico recolhe, transmutando-as em objeto estético. E é, também, "salvação", na medida em que tais vivências e experiências aparecem no jogo poético por ele engendrado através da "metamorfose". A poesia seniana objetiva, antes de tudo, a transformação, a mudança, que vem pelas mãos dos homens. Nesse sentido, ecoa na obra seniana, sobretudo a poética, que é o objeto de estudo presente, uma esperança marcada pela amargura/ desesperança; ou mesmo uma desesperançada esperança, sentida mesmo naqueles versos sonoros de uma catedral aquática, no momento em que o sujeito entede ser a poesia "esta desgraça impotente de actuar no mundo, (...)".

Interessa um outro aspecto da poesia, o entendimento do ato poético como "revelação": de um mundo, ao passo que cria outro. Porque é preciso revelar este mundo infecto em que se vive, como observava o sujeito poético de “"La Cathédrale engloutie», de Debussy”, ainda que isso lhe custe um preço amargo, e, em revelando-o, a poesia que daí nasce cria um mundo outro no poema, não exatamente diferente - trata-se de operação de linguagem - mas um mundo e uma realidade ignorados por todos. A poesia é comprometimento com a realidade que se vive, disso souberam bem os neorrealistas, que, ao período em que se firmavam os últimos números de Presença, sua geração antecessora, firma-se como possibilidade estético-poética cujo compromisso firma-se com a esfera social.

A poesia de Jorge de Sena é uma poesia telúrica, porque brota da experiência mais íntima e pessoal que o sujeito tem da Terra. Assim como a geograficidade de Eric Dardel, que evidencia a relação umbilical do ser humano com a Terra, esta entendida como espaço de condição de realização do próprio humano, de suas vivências e potências, o poema é, para o poeta-engenheiro, o objeto supremo de educação de sensibilidades e de mentes, daí sua preocupação obsessiva em relatar tudo aquilo que viu e ouviu, condição imposta pelo próprio ato de testemunhar, "[...] testemunho, implica, simultaneamente, vestígio e declaração, presentificação de algo que transcende a linguagem pela mesma linguagem, ou como dirá mais tarde Jorge de Sena, 'a poesia como criação de linguagem é supra-real, [...]” (MORNA, 1985, p. 25).

Fica claro, igualmente, a importância do sintagma "dedo sujo" como fio condutor das análises aqui desenvolvidas, tanto pelos motivos expostos ao longo da própria análise, bem como pelo fato de que confirma certo aspecto telúrico da poesia seniana. Nesse sentido, espera-se que 
esta dissertação acerca da relação do sujeito (lírico/empírico) com a paisagem, transpassada pela experiência do exílio, em seu pleno desenvolvimento, possa contribuir para a fortuna crítica da poesia de Jorge de Sena e desdobrar-se em pesquisas outras que investiguem a relação do sujeito com o outro, com quem o poeta mantém um pacto de sincera fidelidade, onde reside, também, seu compromisso ético. 


\section{2 - JORGE DE SENA E O BRASIL: PAISAGENS DE AUSÊNCIA}

No ensaio anterior, falei das relações do poeta Jorge de Sena com a sua terra natal, Lisboa, e, numa paisagem mais ampla, do próprio Portugal. São relações marcadas por uma fina tensão surgida dos versos da página de seu sujeito lírico, e de onde o leitor pode sentir, vindo do lirismo circunstancial de verve goethiana, de modo simultâneo: amor e ódio, esperança e desesperança diante de uma terra que, por mais que tenha escrito, o poeta, ao mundo pertencer, à guisa de cumprir seu papel de testemunha viva do mundo, é-lhe particularmente sua. Sena foi, talvez, excessivamente português, para o bem e para o mal. E o poema condutor das análises anteriormente feitas não poderia ter sido outro que não o narrativo "Em Creta, com o Minotauro", poema-rio de onde os afluentes servem ao propósito de perscrutar, linha a linha e passo a passo, do poeta e do Minotauro, as suas dimensões afetivas frente aos espaços de exílio que o acompanharam por toda a vida.

O poema-rio, já ficou dito, figura como marca escrita e inscrita numa "sujidão/sujeira" na seção "Brasil" de sua Peregrinatio, não menos infecta. A bem da verdade, numa posição bastante central que enfatiza seu caráter de síntese arrebatadora do que o poeta teria vivido até o momento da escritura do poema: duplo exílio, dupla circunstância, a de exílio em solo pátrio, a de exílio em solo brasileiro. E, também, o seu caráter algo como visionário, a sinalizar para as demais vicissitudes pelos quais ele haveria de passar, posto não ser aleatório o estabelecimento da hipótese inscrita no terceiro verso da primeira parte do poema, "[...] serei talvez norte-americano quando lá estiver." (SENA, 2013, p. 516), já prenunciando o seu, já certo, terceiro exílio, em solo norte-americano. Ora, e porque não ter utilizado um poema, ou os poemas, da seção "Portugal"?

A resposta deve ser encontrada neste ensaio, que parte do mesmo poema e se expande a outros, na tentativa de explorar as visões de uma paisagem brasileira, se perceptível, na poesia de Jorge de Sena. Aliás, talvez mesmo antes de trilhar um caminho de resposta à pergunta anteriormente posta, o ensaio mesmo em sua totalidade já seria a sua resposta e sua inteireza, seria melhor tentar saber do que se trata esta tal "paisagem brasileira", cujas figurações tento rastrear pelos vestígios poéticos dos poemas de sua peregrinação infecta. E, de maneira bastante precoce, seria de boa valia entender que uma paisagem brasileira diz respeito fundamentalmente à constituição de uma imagem mental do Brasil a partir da organização efetiva e ordenadora dos sentidos, visão e audição, por sobre aquilo que percebem em solo brasileiro. Ou seja, como assinala Besse (2014), em ensaio sobre as problemáticas em torno do conceito e do estudo de paisagens na 
modernidade e contemporaneidade, conceito este que extrapola os campos de preocupação do geógrafo, uma vez que a paisagem é objeto de interesse para o paisagista, o arquiteto, o teórico literário, o sociólogo, antropólogo, etc. E explica:

Uma primeira abordagem da paisagem consiste em defini-la como um ponto de vista, um modo de pensar e de perceber, principalmente como uma dimensão da vida mental do ser humano. A paisagem não existe, objetivamente, nem em si; então ela é relativa ao que os homens pensam dela, ao que percebem dela e ao que dizem dela. Ela é um tipo de grade (retícula) mental, um véu mental que o ser humano coloca entre ele mesmo e o mundo, produzindo, com essa operação, a paisagem propriamente dita. [...] A paisagem é uma interpretação, uma "leitura". Não existe em si, mas na relação com um sujeito individual ou coletivo que a faz existir como uma dimensão da apropriação cultural do mundo. A paisagem falanos dos homens, dos seus olhares e dos seus valores, e não propriamente do mundo exterior. Na realidade, só haveria paisagens interiores, mesmo se essa interioridade se traduz e se inscreve "no exterior", no mundo. (BESSE, 2014, p. 13)

Uma paisagem brasileira seria justamente aquilo que o sujeito Jorge de Sena consegue ver e ouvir, ou talvez melhor: tudo aquilo que ele consegue abarcar de genuinamente brasileiro por meio de seus sentidos, mesmo localizado num lugar incomodo, como o é o de toda a testemunha. A paisagem brasileira, se possível sua existência, torno a marcar, surgirá mediada, assim como a portuguesa, pela estruturação de um sujeito lírico, cujo biografema não corresponde a um sujeito confessional e nem fingidor. Mas se se leva em consideração o título da seção de que agora me ocupo, "Brasil", o erro é certo, na medida em que, se for feito o cotejo atento aos sinais de Brasil nos poemas, a ideia primeira desfaz-se numa quase completa ausência de Brasil numa seção que, por princípio, deveria ser-lhe toda dedicada.

Entretanto, isso é também o jogo do testemunho seniano: a circunstância é-lhe fundamental, isso já ficou dito anteriormente e é algo inegável na leitura da obra de Jorge de Sena. A circunstância enformadora de sua Peregrinatio, ou seja, o que lhe dá coerência interna e externa temática e em relação ao mundo, o que testemunha - é, sobretudo, a situação de exílio, não exatamente a dimensão geográfica, ou o estar neste ou naquele país, seja ele um Portugal idealizado (o Portugal que ele imagina ser o melhor) ou o Brasil ou Estados Unidos da América. Nesse sentido, parece que a ausência de um Brasil na seção que lhe presta homenagem, antes de indicar a não formação de um panorama preciso acerca da pátria que o acolheu em seu exílio fora de sua terra, sinaliza precisamente para a constituição de uma paisagem formada pela ausência.

Uma ausência sobre a qual muito tem a ser dito, a começar pela epígrafe da seção, brevemente analisada, mas cujo sentido de integração ao percurso dos poemas de sua seção parecem garantir uma força ainda maior, a ela e aos poemas. Ora, o poeta traz Horácio à sua 
peregrinação, referência clássica com quem dialoga, e não só. Numa estrofe de quatro versos, ao ler Horácio, parece que se lê o próprio Jorge de Sena: ali, na epígrafe, há a sinalização de possibilidade acerca da brevidade da vida, que resvala numa afirmação enfática questionadora do seu próprio sentido, o da vida e o da peregrinação. Se a vida é breve, diz o clássico latino, vale a pena explorar outras terras que não a sua própria? E, mais, explorar outras terras, tendo como consequência última um estrangeirar-se de sua própria terra natal, vale a pena?

Horácio não responde, pelo menos não nos versos que o poeta português recupera na constituição de sua epígrafe, a resposta fica aérea, numa suspensão que parece mesmo apontar para uma resposta possível, mas não textualmente grafada, num jogo quase performativo próprio de uma retórica. Ele, Jorge de Sena, parece, entretanto, oferecer uma resposta longa e presente em toda a sua obra, na medida em que a questão do tempo e sua relação com os espaços e lugares, paisagens já tornadas objetos estéticos de grande força evocativa, foi-lhe sempre bastante presente. E isto começaria, nesta seção (não)-brasileira, com a presença da imagem de um vespertino no e do Rio de Janeiro.

\section{VESPERTINO DO RIO DE JANEIRO}

Na noite as luzes furam treva, não para além dela, mas de mim com ela; não sei se arranha-céus, ou se favelas que lado a lado arranham morros para sustento de miséria. Imenso mar, de altíssimas sombrias transparências, na noite em que perpasso qual silêncio. Não sei se amor me evita ou me protege, ou se é de amor que eu velo o brando sono ruidoso e povoado.

Meu coração é só de amor que sabe; mas o que sabe, de saudoso esquece, na angústia dúplice de não ter-te ao lado.

$$
22 / 8 / 1959
$$

(SENA, 2013, p. 469)

O Brasil começa a ser delineado, na poesia de Peregrinatio, através de uma porção sua: o primeiro poema da seção que leva o nome do segundo exílio seniano traz no título a grafia "Rio de Janeiro", estado brasileiro sobre o qual o poeta delineia poeticamente a imagem de um vespertino. Resisto à ideia de pensar que algo pode ser aleatório na poesia de Jorge de Sena, seja a seleção 
titular, a forma do poema, ou a constituição de sua obra, porque ali tudo parece concorrer junto para a composição unificadora e coesa de uma obra tão profícua quanto é sua. Sendo assim, não me parece aleatória a escolha de um período do tempo como o vespertino, muito menos o Rio de Janeiro, para início de uma seção que tem na ausência da figura do Brasil talvez uma marca muito chamativa, para não dizer absolutamente curiosa.

O vespertino carrega em si mesmo uma ideia de transição, afinal, não é plenamente dia ou tarde, nem sequer plenamente noite: é o período de interregno entre o dia e a noite, entre o claro e o escuro. Ora, isso aparece no poema a partir da localização temporal da circunstância do poema num momento de "noite" atravessado por "luzes". Vocábulos marcantes na poesia de Jorge de Sena, e, assim, na sua peregrinação infecta, "noite", "luzes" e "trevas" marcam momentos poéticos constituidores de imagens muito próprias. Ao inserir o espaço do Rio de Janeiro num momento que é, por natureza, intervalar - indefinido, mas pleno de significações - o poeta parece retornar a algumas imagens que iniciam poemas da seção anterior, "Portugal", ou mesmo imagens e escolhas vocabulares que marcam o estilo seniano.

Basta que se atente para o fato de que, se em "A Sophia de Mello Breyner Andresen enviando-lhe um exemplar de «Pedra Filosofal»", poema de abertura da seção portuguesa com uma reflexão sobre a criação poética, equiparada, no poema, à criação dos filhos. Ambos, Sophia e Sena, poetas e pais, numa reflexão que não é somente direcionada à sua muito amiga, as cartas que trocaram dessa amizade afetuosa dão conta, mas também direcionada a si próprio. Há, nos dois objetos, aqui no sentido do elemento outro, poema e filhos, um movimento final que é o de dá-los ao mundo, mas como? Pergunta o poeta, que, à guisa de perguntas retóricas, como quem sabe desde o início muito bem a resposta da pergunta feita, tece novas e outras perguntas, a criar um esquema analógico que, ao mesmo tempo que pergunta, tem ali a resposta implícita, suspensa.

Mas não é desse poema em específico que volto à atenção. É o poema seguinte, ou os poemas seguintes sobre os quais me debruçarei, na medida em que um parece continuar, temática e visualmente, apesar das diferenças formais, a constituição imagética do anterior. Sendo assim, "Vampiro" é o primeiro elo de conexão poética que estabeleço entre as duas seções: sensorial, aliás, uma combinação de sons e imagens, que, na obra do poeta, não é recurso novo - basta lembrar a criação imagético-sonora de sua catedral aquática, sobre o que se falou no ensaio anterior -, o leitor depara-se com o espaço urbano da cidade, marcado por suas ruas, cortadas por automóveis modernos, pelo "eléctrico!" - "Mais longe some-se o rodar de um eléctrico" (SENA, 2013, p. 4578). O poeta estabelece uma atmosfera algo gótica, criada em elevada progressão, como num 
crescendo cujo ápice seria o surgimento de uma figura - vampiro? O sujeito? - a falar de um sangue puro de que não bebeu.

Seria o sujeito que, "como na morte dormirei, e digerindo / o sangue puro que te não bebi" (SENA, 2013, p. 457-8), o vampiro, e o sangue, representação de uma terra, a terra natal do ser do poeta com quem estabelece relações plenamente difusas? Um dia, fiz essa associação, hoje, algo forçada ${ }^{39}$. Talvez não importe se a relação é essa mesma, mas sim enxergar o comportamento do sujeito do poema e como a tensão com o espaço urbano é constituída, igualmente em crescendo, assim como a tensão rítmica do resto do poema. Mas importa, aqui e sobretudo, as imagens relativas à noite: “escamas luzidias", "sono plúmbeo", "morte”, “ondas silenciosas”, "sangue puro", vocábulos que ganham ainda mais força no voo imagético engendrado pela "«Ave Nocturna...», seu poema imediatamente posterior.

Em "Vampiro", há os gatos que brincam, disso sabe-se porque o sujeito os ouve brincar, pelo menos até o momento do aparecimento inesperado de um outro sujeito - aqui já são dois, um "eu" e o outro, "tu" - completamente inebriante e desconhecido. Ele, o "outro", o agarra pela nuca, põe o sujeito lírico em estado de dúvida, a ponto de se questionar se os gatos continuam a brincar e se os carros continuam a passar. Continuam, de fato, mas importa o momento de êxtase que circula a fim do poema, concretizado pela transformação do eu no outro, na medida em que, os dois últimos versos dão conta, quem bebe o sangue puro de quem é a própria voz do poema. Ainda assim, resta o sangue, puro e suspenso, intacto porque não bebido. Este mesmo "sangue" é importante guardar, enquanto imagem que reaparecerá mais tarde, no seu poema "Relatório", de data $7 / 5 / 1969$.

\section{VAMPIRO}

Ouço os gatos brincar. Saltam, perseguem-se.

Da rua, cuja noite um automóvel corta,

\footnotetext{
${ }^{39}$ Esta chave de leitura pode ser encontrada em "Figurações da Terra natal na poesia de exílio de Jorge de Sena", monografia de conclusão de curso de Letras (Port./Ingl) apresentada à banca composta pelos Professores Doutores Luciano Façanha (DEFIL) e Rafael Quevedo (DELER), da Universidade Federal do Maranhão. Ali, aventava a possibilidade de o poema ser uma reflexão metafórica acerca da relação do poeta (sujeito poético) com a sua Terra natal, Portugal. Cito-me: "O sujeito lírico, vampiro, testemunha a vida que passa pela cidade para que, daí, exponha a si mesmo, no que diz respeito à sua relação com o espaço em que vive. Uma relação profundamente marcada pela peculiar tensão dialética da aproximação e do afastamento, que, em síntese, é o conteúdo todo do poema. Parece-nos forte a evidência de que aí fala uma voz que é a do próprio Jorge de Sena a tratar de sua relação íntima com Portugal, ao mesmo tempo próximo e distante, amado e odiado. O país natal e o poeta são, no poema, a vítima e o vampiro, que desenvolvem uma espécie de danças nas sombras, a própria dialética de que falamos acima." (SANTOS, A., 2014, p. 52). É sobre esta associação apressada, de entender o poema como tendo referente preciso Portugal, em sua relação com o sangue e o vampiro - que há, e isso confirma-se posteriormente na leitura, mas numa correlação ao mar - que pareço não estar de acordo por agora.
} 
chegam-me risos, vozear distante.

Mais longe some-se o rodar de um eléctrico.

Tremem-me as mãos só de lembrar que pude

abandonar-te ao teu desejo agudo, quando tão junto ao meu o contiveste, julgando que submisso eu te seguia.

Tremem-me as mãos, as coisas me são estranhas, algo me agarra pela nuca e me arrebata por sibilantes portas sucessivas de que ouço os gonzos respirar-me a vida.

Os gatos brincam? Outro carro passa?

Outros regressam? Viram-te? Tiveram-te?

Sou eu quem está dentro de ti com eles?

Num vácuo de escamas luzidias, o sono plúmbeo me rodeia, ataca por ondas silenciosas e concêntricas. como na morte dormirei, e digerindo o sangue puro que te não bebi. $9 / 12 / 1950$

(SENA, 2013, p. 457-8)

Da escritura e publicação de "Vampiro" a "«Ave Nocturna»", conta-se um ano. Desses dois poemas ao "Vespertino do Rio de Janeiro", nove e oito anos, respectivamente. E é como se não houvesse uma distância temporal significativa, pois, ainda assim, há um resgate importante de imagens, de sons, de ideias. Ou também, a permanência, de uma posição ética fundamentadora de um ser e estar no mundo a partir de uma relação de cuidado e de atenção vigilante, sempre altivos e ativos, com o mundo e com o outro, logo, consigo mesmo. É nesse compasso que a ave seniana, "nocturna", aparece num poema constituído em sua estrutura pela justaposição de palavras, de imagens, cujo sentido ora parece ser mais claro, ora mais obscuro. Veja-se, a exemplo, a associação feita, logo no primeiro verso, entre "ave nocturna" e "ponte de cometas": "Ave nocturna ponte de cometas", ou entre "nuvens douradas caudas era um peixe", no sexto verso.

O espaçamento entre os sintagmas é do próprio poema e são uma forma e um estilo propositados. Quais correlações tirar dessas associações potentes que circulam neste poema seniano, intercaladas com outros versos que apresentam imagens dispostas de maneira aproximada da linguagem corrente, mais aproximadas de um ordenamento padrão de organização do pensamento? Tanto a "ave nocturna" seniana, que lá do alto alça seu voo e observa a partir de seu olhar o mundo cá embaixo, quanto o "vampiro", ele mesmo tornado um "eu" cujo sangue não bebe, estão imersos numa dimensão temporal que é a matéria de feitura própria dos poemas em 
questão. Tempo que se faz distância, distância que se faz tempo, numa ideia que é matéria temática própria da poesia seniana.

\section{«AVE NOCTURNA...»}

Ave nocturna ponte de cometas Invalidada túnica de simples pregas direi que me conheces quando pelas ruas as luzes na manhã futura já se apagam como pensamentos que se fecham sobre o impossível nuvens douradas caudas era um peixe tranquilamente preso a gestos de água fria que entre pedras assa queres ah chamar-me seguram-me se fujo o fogo queima é uma verdade sabe-se tudo o que eu diria te queimava ah nunca mais nos passos vagos terei o sentido das colunas que se partem

leve da tua passagem

[ao sopro

nunca mais na treva encontrarei as marcas

luminosas que os teus dedos deixaram ao passar na minha

pétalas rasgadas de flores que pensei

[fronte como

como prados passados na chuva do teu sangue sobre o meu

Nunca mais auroras que nasciam

ventos que cruzavam com mais ventos

doutras eras

doutros lugares

de sítios

a que nunca fui senão comigo mesmo e aonde levarei ardente nas mãos entreabertas só memória das tuas

entre os dedos se partem

e são pedaços pousados no chão sujo

de tantas poluções perdidas

que os pés pisam

nesta viagem à beira de outro rio

negro oleoso crespo e oleoso e crespo como sabes

nunca mais.

1951

(SENA, 2013, p. 458-9)

E, ali, a quase fim do poema, ecoa a imagem dos dedos que se partem após o contato entre mãos e dedos, afetos, de um e do outro, que carregam memória, talvez uma memória já antecipadamente suja: "levarei ardente nas mãos entreabertas / só memória das tuas / entre os 
dedos se partem”. A disposição gráfica dos versos parece mesmo sinalizar um voo cujo percurso final, objeto de memória, repousa "e são pedaços pousados no chão sujo". No momento em que os dedos se partem e caem ao chão, sujo, tornam-se eles, também, sujos. Seria já o "dedo sujo" potente e expressivo de suas investigações das origens da vida, tidas em Creta, junto do Minotauro, seu companheiro de destino e de peregrinação? E, no entanto, é talvez pelos olhos da "ave nocturna" que o vespertino do e no Rio de Janeiro poderá ser visto.

Do olhar atento daquela "ave nocturna", no vasto céu aberto, o leitor pode se dar conta de que aqui, no vespertino, o cenário já não parece ser de conflito, como ocorre nos dois poemas acima referidos: há, no "Vampiro", um jogo de afastamento e aproximação, e, por fim, transmutação, quase camoniano à la "torna-se o amador na cousa amada"; no outro, um sentimento de que não volta jamais a experiência vivida, posto sobreviver somente como marca do tempo passado, irrecuperável, a não ser pela memória, e, por isso mesmo, diferente do tempo vivido em presença. No vespertino seniano, esse jogo pode até ser identificável no seu final, através de uma angústia provinda de uma dor de ausência.

Ausência de quê, resta saber? Ora, atente-se para os versos iniciais, sobretudo o segundo, já que o primeiro situa temporalmente o poema: "para além dela, mas de mim com ela;". Não se trata de um eu isolado de um "outro". O espaço da poesia seniana é plenamente povoado por um "eu", um sujeito vivo e operante, mas também por um “tu”, também ele vivo e com quem mantém profundas relações éticas, uma vez que assume seu compromisso de testemunhar. É dessa relação do si-mesmo com o outro de que fala o poema, sob o pano de fundo de um momento intervalar e significativo. É, também, desta relação e deste momento que aparecem cenários possivelmente identificáveis com o espaço urbano do Rio de Janeiro.

Sobre o compromisso de testemunhar, recupero o embate entre os homens de Presença e neorrealistas, no que os escritos de José Régio tem de contribuição. A Presença tem seu início em Portugal no ano de 1927, no mês de Março, aquando da publicação de Literatura Viva, folha crítica de autoria de José Régio. Ali, o crítico e poeta dá um diagnóstico preciso da produção poética (literária) de Portugal do período, soterrada que estava por uma movimentação literária de cunho livresco, em todos os sentidos oposta ao conceito de "Literatura Viva" que ele irá propor como a mais alta expressão do poético. A “Literatura Viva” é, assim, o reconhecimento da originalidade e da personalidade do autor (poeta) em sua obra, coisas que o poeta não conseguia perceber nos poetas que àquele momento se apresentavam - a dimensão da poesia de Fernando Pessoa ainda era incógnito à época. 
Da associação entre "originalidade" 40 e "vida", José Régio postula sua ideia de arte viva, a destacar os vícios que abatiam a produção artística portuguesa do período, a saber, dois: a falta de originalidade e a falta de personalidade. Não é original aquela obra que se circunscreve ao plano meramente individual, sem jamais ascender a um plano coletivo de identificação. Há aí, aponta o crítico, a "substituição da personalidade pelo estilo" (RÉGIO, 1927, p. 80) ${ }^{41}$, muito cheio de retóricas e pedantismos que soterram qualquer possibilidade de aparecimento de uma originalidade genuína. E, além, o crítico conclui que, se falta originalidade (ou se ela é pouca em letras portuguesas), daí decorre sua falta de sinceridade.

E o que viria a ser esta sinceridade de que tanto fala José Régio, senão aquela consciência mesma do artista em produzir uma obra viva, onde a vida do autor esteja insuflada à vida da obra, de modo que ali sejam percebidos a personalidade própria, seu labor estético e a sua vivacidade? Certamente, o crítico melhor se explica; trago-o, portanto:

A expressão directa, simples, orgânicamente ingénua, tenta sem dúvida o artista moderno; mas não parece ser característica dele. Os artistas de hoje mais directos, mais simples, mais ingénuos - são-no conscientemente. Salvo raríssimas excepções. Ora ser conscientemente ingénuo, simples, directo, já é complicar-se. A complicação que julgo ver na Arte moderna pode, pois, tomar aparências de pouca sinceridade: $\mathrm{O}$ lirismo e a ironia, o abandono e a atitude, o sub-consciente e a razão - emaranham-se na arte de vários mestres contemporâneos. (RÉGIO, 1927, In: SIMÕES, 1957, p. 80)

O artigo de José Régio define as bases, de certa maneira, do que viria ser o movimento de Presença, e, num artigo posterior, aquando da publicação do número 9 da revista, no ano de 1928, sai também de sua própria autoria o artigo "Literatura Livresca e Literatura Viva", no qual alarga as ideias postas em seu anterior, "Literatura Viva", expondo, de fato, as diferenciações entre uma literatura original (viva) e uma literatura de cunho livresco (morta).

A associação da Literatura com a Vida não era, contudo, algo particularmente novo: já quarenta anos antes, aponta Guimarães (1969) ${ }^{42}$, em “A Literatura Portuguesa Contemporânea”,

\footnotetext{
40 "Essa originalidade, porém, não se traduzia numa consciência de ruptura relativamente a um passado literário; seria antes, na óptica de José Régio, o desvio que se desenhava quanto a esse passado pela procura de uma sinceridade que desvelaria a 'parte mais virgem, mais verdadeira e mais íntima duma personalidade artística'. Em vez da grande recusa própria da Vanguarda, aceitava-se o próprio momento de afirmação da presença criadora do artista que a partir de si mesmo se revelaria não pela negação e a subversão de formas que polemicamente recusava, mas pela essencial descoberta desse alguém que ele era e, paradoxalmente, desse espaço quase sem referências que representaria o que há talvez de imutável e eterno na própria arte. [...]” (GUIMARÃES, 1989, p. 23)

${ }^{41}$ In: SIMÕES, 1957, p. 80

42 "Trata-se de uma perspectiva onde se procura detectar, a traços largos, a «personalidade e a inteligência da nossa literatura». Esta espécie de balanços, pelo menos com certo fôlego e despidos de uma intenção historicizante, não são muito frequentes entre nós. Recordemos que, cerca de quarenta anos antes, saíra numa outra conhecida publicação a Revista de Portugal, dirigida por Eça de Queirós - um artigo de Moniz Barreto que se apresentava como um conspecto geral da situação da nossa literatura nos fins do século XIX. O seu título era este: A Literatura Portuguesa Contemporânea.
} 
Moniz Barreto apresenta a Literatura enquanto “concepção" ou “impressão da Vida". Portanto, resguardadas as devidas proporções - à época de Barreto, a oposição se daria entre uma literatura de "imaginação psicológica" e outra de "espírito filosófico" - não parece ser nova a distinção entre uma literatura viva e outra livresca. Ao menos, não é nova pelo uso dos termos, senão na perspectiva diferenciada proposta por José Régio.

Ora, se quer José Régio apontar para um entendimento da arte a partir da consciência integrada ente o artista e seus dons, é verdade que àquela época pairava ainda uma certa crença na independência da arte em relação às suas circunstâncias formadoras: "Em Coimbra, os rapazes chegados aos vinte e cinco anos, ou em vésperas dessa meta da plena juventude, ainda viviam sob o influxo de uma liberdade que permitia acreditar numa independência total da literatura e da arte relativamente à política e aos destinos da sociedade humana." (SIMÕES, 1957, p. 33) Isto significa que aos homens de Presença interessava a arte em sua pura essência, uma arte desvinculada das preocupações sócio-políticas do pós-Guerra, e sobretudo em Portugal, que passa a viver o início de sua longa ditadura militar.

Tratava-se da questão clássica em literatura, tanto quanto aquela sobre o que é literatura, da distinção entre "arte pura" e "arte social". Aos homens de Presença não interessava a arte compromissada com a vida política, o que dá à arte presencista uma dimensão psicologista no que se refere ao enfrentamento, em arte, dos conflitos sociais do período. Resguardada sua devida importância para as letras portuguesas, em especial para Jorge de Sena, cuja noção e apego ao rigor estético será um valor presencista por ele muito bem aproveitado, o Presencismo viria a ser alvo de duras críticas, sobretudo por parte de uma nova geração que se avizinhava próxima ao surgimento de seu último número, a geração neorrealista, que insere o eu social (ou a vida social e seus problemas) na constituição da obra literária, em clara distinção à orientação presencista.

Numa poesia que muito pouco tem de evocação ao campo e a uma certa concepção de natureza contemplativa, cujo resultado é o afastamento, ainda que simbolicamente, entre homem e espaço circundante, Jorge de Sena opera o sentimento contrário ao colocar em destaque um espaço urbano - seja o de Lisboa, do Rio de Janeiro, ou, posteriormente, o dos Estados Unidos,

\footnotetext{
Não se falava aí de literatura viva, mas, ao reconhecer-se expressamente que a «a Literatura representa uma concepção ou uma impressão da Vida», atribui-se-lhe um enraizamento que marca virtualmente a sua possibilidade de entreabrir uma consciencialização que - ao oscilar entre dois limites que poderíamos designar, de acordo com a nomenclatura típica da época, por imaginação psicológica e espírito filosófico - era capaz de ultrapassar o que houvesse de artificioso num equilíbrio verbal meramente formalista, exemplificável, na opinião de Barreto, com o muito que escreveu o «literato» Castilho. Essa consciencialização era, do mesmo modo, um alargamento do horizonte entrevisto pelos nossos escritores graças a um maior contacto com as criações realizadas além fronteiras . «A última geração literária - di-lo expressamente - distingue-se das que a precederam por dois traços: a preponderância da reflexão e a influência do estrangeiro»." (GUIMARÃES, 1969, pp. 14-15)
} 
para ficar apenas nesses espaços de exílio -, espaço este marcado pelas gritantes dicotomias (riqueza versus desigualdade) e questões próprias de uma sociedade moderna cada vez mais individualizada e fraturada pelos avanços brutais de uma lógica capitalista que danifica e é perversa à cidade..

Importa a Jorge de Sena aquele conjunto de paisagens urbanas ligadas à cidade do Rio de Janeiro: "arranha-céus", "favelas", "morros". São imagens postas em contraponto: de um lado, os "arranha-céus", os prédios portentosos da cidade carioca; do outro, "favelas" que "arranham morros para / sustento de miséria.". Arranha-céus e favelas, imagens-marco de uma sociedade plenamente desigual, surgem como símbolo, portanto, não só de uma certa modernidade, mas de uma desigualdade que não faz questão alguma de ser escondida: ambos, espaços urbanos, constituídos, o primeiro, a partir de uma ótica vertical; o segundo, de uma ótica horizontal, não estão apartados e tão distantes quanto se poderia pensar. O limite que demarca o final de um desses espaços é o mesmo que aponta para o início do outro.

Contudo, não é um cenário que se esvai em si mesmo, em sua separação interna, porque surge no poema não como coisa apensa, ou reflexão menor. É que há uma outra separação, igualmente dolorosa para o sujeito poético que observa, com o voo da "ave nocturna", o vespertino na capital carioca. A separação brutal, menos que divisão, entre espaços de pobreza (favelas) e de riqueza (arranha-céus) toca necessariamente o coração do poeta e é divisada com uma outra separação que tem como marca o espaço marítimo. O “mar”" espaço de aconchego cuja espacialidade, ou imensidão, convida à ventura. Não há como dissociar a constituição de uma história da identidade portuguesa sem passar pelo tópico do mar, da saudade. Jorge de Sena a ele não foi indiferente.

Falo de mar e de saudade, uma ideia associada à outra, e as duas associadas à uma identidade portuguesa numa chave de leitura que não é nova. Aliás, uma leitura radicada naquela da identidade

\footnotetext{
43 Cf. "O mar na poesia de Jorge de Sena", de autoria de Belchior (1981), In: SHARRER, Harvey L. e WILLIAMS, Frederick G. Studies on Jorge de Sena By His Colleagues and Friends. Santa Barbara, CA: Jorge de Sena Center for Portuguese Studies/ Bandanna Books, 1981.

Belchior (1981) recorre a uma série de imagens referentes ao "mar", na poesia seniana de modo geral. Em torno da Peregrinação Infecta, a estudiosa aponta o poema "Travessia" como um dos poucos que dá notícias do mar: "Após cinco dias de sonolenta travessia / quase sem barcos, e sem nenhuma ilha, / apenas sobre um mar de ondeado azul sombrio / ou de estanhada palidez monótona (Poesia-III, p. 103). Mas num verso indiscutivelmente significativo, a confissão: 'ó mar - perene sangue a que regresso' (p. 103)". Como se se tratasse de um retorno a uma temática que muito lhe importa. Acrescentaria, entretanto, outros poemas: "A Sophia de Mello Breyner Andresen enviando-lhe um exemplar de Pedra Filosofal", onde "praia" e "sombra de corais" são imagens fortes a falar da poética de Sophia, ou mesmo da sua; "Vespertino do Rio de Janeiro", onde se afigura a imagem do "mar imenso" que separa o sujeito poético de Portugal, sua pátria: é do Rio de Janeiro, no outro lado do Atlântico, que o poeta observa o mar imenso e, de após ele, o Portugal. Ou o que dizer da imagem poética da descida do sol: "o sol serenamente desce sobre o mar," (Poesia 1, 2013 , p. 517) que compõe a paisagem onde tomam café, mexido com o dedo sujo "de investigar as origens da vida" (p. 517), o poeta e o minotauro? Senão que são indícios de uma paisagem marcadamente humana e marítima.
} 
portuguesa pelo olhar atento de Eduardo Lourenço, quem tanto escreveu sobre Portugal, sua terra, como o fora a de Sena, sobre quem também escreveu. Para o crítico português, a saudade estaria fundamentalmente relacionada a uma postura ou um modo de estar no mundo em relação ao Tempo, ou à história. O sentimento de saudade é, pois, efeito de uma condição de ser-se sujeito temporal, inscrito num tempo. Nesse sentido, haveria outras modulações, além da saudade, que dariam conta dessa relação, quais sejam: melancolia e nostalgia. O crítico seguramente melhor se explica, por isso, a ele:

Voltar-se para o passado, lembrar-se, não é nunca um ato neutro, mas essa regressão constitutiva da memória pode ser vivida apenas como simples alusão, mero sinal endereçado aos acontecimentos que salpicam. [...] Os "regressos" específicos da melancolia, da nostalgia, da saudade são de outra ordem: conferem um sentido ao passado que por meio delas convocamos. Inventam-no como ficção. A melancolia visa o passado como definitivamente passado e, a esse título, é a primeira e mais aguda expressão da temporalidade, aquela que a lírica universal jamais se cansará de evocar. A nostalgia fixa-se num passado determinado, num lugar, num momento, objetos de desejo fora do nosso alcance, mas ainda real ou imaginariamente recuperável. A saudade participa de uma e de outra, mas de uma maneira paradoxal, tão estranha - como é estranha e paradoxal a relação dos portugueses com o "seu" tempo - que, com razão, se tornou num labirinto e num enigma para aqueles que a experimentam como o mais misterioso e o mais precioso dos sentimentos. (LOURENÇO, E. 1999, p. 13)

A saudade estaria, portanto, ela mesma situada em um espaço intermédio cujos extremos seriam a melancolia e a nostalgia. Não cabe aqui identificar, na poesia seniana, de que maneira - se pela via da nostalgia, da saudade ou da melancolia - o poeta soluciona, se é que assim procede, as tensões que manteve com Portugal durante toda a sua vida, mas a contribuição de Eduardo Lourenço é fundamental, sobretudo para que se entenda a defesa de uma postura outra, uma terceira margem, como a que dá nome ao conhecido conto de Guimarães Rosa, que possibilita a Jorge de Sena optar por um enfretamento de sua condição de ser-se inevitavelmente português e, portanto, de estar inscrito numa temporalidade que não pode ser ignorada. A saudade, na reflexãosíntese de Sílvio Renato Jorge ${ }^{44}$ aqui recuperada, transforma-se, pois, numa mágoa ou desprezo por Portugal.

É importante guardar a ideia que o crítico brasileiro oferece como via possível aos usos anteriormente descritos de modulações temporais identificadas na vida portuguesa e na literatura - saudades, quem já não as cantou? - mas que se guarde, porque a ela retorno mais adiante, numa

\footnotetext{
${ }^{44}$ Sílvio Renato Jorge, crítico brasileiro, parte do entendimento de Eduardo Lourenço acerca da tríade - melancolia, saudade e nostalgia -, portanto, a relação do português com o (seu) Tempo e seu lugar na história, para localizar o lugar de Jorge de Sena, "o poeta sem fronteiras", em título instigante de seu ensaio, no lugar da mágoa e do desprež. No lugar da indiferença à Portugal, portanto. Mas é preciso entender melhor esse sentimento, detalhado a seguir no ensaio, porque ele não significa ausência da terra portuguesa na poesia de Jorge de Sena. É o radical oposto, aliás, o que aparece acontecer.
} 
ideia de correspondência sentimental, para entender os efeitos colaterais de adoção de uma postura como a da negação e do desprezo, no vislumbre de paisagens outras, como a do Brasil e a dos Estados Unidos. No caso brasileiro, a paisagem que é construída por sua absoluta ausência no verso de sua Peregrinatio ad Loca Infecta ganha outros contornos, presentes e grafados, portanto, inscritos em textos outros que não poéticos, nos quais o poeta esclarece de modo confessional a relação mantida com o seu segundo destino de desterro.

De volta ao poema, ou melhor, retomando-o, na medida em que dele não saí, a não ser num ato digressivo para melhor entender sua inscrição no arco de entendimento das relações confusas e concretas estabelecidas entre o sujeito português e uma pátria brasileira, a sua pátria, seria possível dizer, aliás? É mais seguro seguir.

\section{$[\ldots]$}

Imenso mar, de altíssimas sombrias transparências, na noite em que perpasso qual silêncio.

(SENA, 2013, p. 469)

E se há uma separação, de igual dimensão sentimental, como apontado um pouco acima, quais são os polos que ela marca e divide? Ora, o primeiro parece bem destacado pelo título do poema, seguido da evocação de espaços e imagens que caracterizam plenamente o cenário do Rio de Janeiro; o mar separa esta primeira paisagem de uma outra, cujos espaços específicos não são plenamente identificáveis. Seria Portugal o outro espaço separado pelo mar? A noite já avança, o poema disso nos dá conta, as ondas são já altíssimas transparências, surgidas como interposição, limite, como mediação entre espaços, como num espaço fronteiriço, que, contudo, não impedem a visão do que está além, muito menos um atravessamento dum "eu” pelo “outro", mas disso já se sabe, pelo menos desde o segundo verso do poema.

Já é noite e, diferentemente dos poemas anteriores, os dois primeiros da seção portuguesa, que parecem oferecer ao leitor uma sensação de ruído e barulho que atravessam a noite por completo; no "Vespertino" repousa um silêncio significativo advindo do não saber as origens e consequências de um amor que o sujeito direciona não se sabe a quem ou a que: se a um "tu", ou se a uma pátria específica, Portugal. As duas possibilidades parecem fazer sentido: numa chave, se o sujeito fala de um "tu”, fala de sua posição delicada, ele é testemunha afinal, que se deixa atravessar sempre pelo outro. Numa outra chave, se o sujeito está a falar do sentimento por sua terra, o amor também exerceria papel fundamental. Em ambos os casos, o amor "me evita ou me 
protege?”, e finaliza o poeta o verso com “ou se é de amor que eu velo o brando sono / ruidoso e povoado".

\section{$[\ldots]$}

Meu coração é só de amor que sabe;

Mas o que sabe, de saudoso esquece,

$\mathrm{Na}$ angústia dúplice de não ter-te ao lado.

(SENA, 2013, p. 469)

Se a noite é marcada pelo silêncio, pelo menos aparentemente, o sono é "ruidoso e povoado", porque é um sono marcado pela incerteza dos efeitos do amor no ser do sujeito. Mas sobretudo amor, porque "meu coração é só de amor que sabe", ainda que esse saber esteja marcado pelo esquecimento provocado por uma saudade de não ter ao lado de si o objeto de que fala o poema - "na angústia dúplice de não ter-te ao lado.". O sujeito conforma-se pela ausência, mas essa conformação na poesia de Jorge de Sena sempre é marcada por um sentimento de inquietude, como quem se conforma mas espera, resguarda. Assim é que é construída, no que concerne ao sentimento do poeta por Portugal, o terreno de afetividades - positivas e negativas - com que inunda vários de seus poemas, o "Vespertino do Rio de Janeiro" sendo um deles.

E o que fica de Brasil do poema? O poeta falou do Rio de Janeiro, afinal é o espaço onde o poema é criado, é o espaço fornecedor de uma circunstância que evoca ainda que delicadamente, se bem que proposital, a questão ética e social da separação e desigualdade social que ainda é a marca de uma cidade, ou melhor, de um país rico em diversidade natural como o Brasil. Há, no poema acima, portanto, um sabor de Brasil, inscrito num jogo dialético travado no campo da presença-ausência, de que os poemas a seguir analisados reforçam a premissa inicialmente elaborada - a construção poético-imagética de uma paisagem de desterro pela ausência - e reforçada nos argumentos em desenvolvimento apresentados.

O poema a seguir, assim como os anteriores, reforça duas coisas importantes na poética seniana: o jogo sensorial a mesclar os diversos sentidos humanos, numa experiência poética que dá a ver a primazia do ver e do ouvir - afinal, o título e primeira oração do primeiro verso, "quem muito viu", poderiam também ser facilmente substituídos por outra: "quem muito ouviu" - uma vez que são sentidos altamente potentes na captação de experiências humanas; a outra diz respeito à capacidade de transmutação poética que o poeta investe a esses mesmos sentidos: a poesia não surge num processo direto e imediato dos sentidos, senão pela capacidade mental de organização do dado vivido em dado poético. Nesse sentido, a poesia (o poema) seniano é sempre uma 
construção em ato, está sempre pronto a surgir, a emergir de uma consciência algo automática e de uma vez somente, que lembra o seu apego não doutrinário ao Surrealismo, naquilo que ele tem de método de escrita.

Escrito no ano de 1961 e, portanto, temporalmente inscrito no período brasileiro da grande peregrinação de Jorge de Sena, o poema “"Quem muito viu...»” é exemplo do que foi falado acima. Outros poemas haveriam, também, de ser gratos exemplos, mas este em especial traz à tona a questão do exílio de maneira mais evidente, ou seja, a problemática do afastamento do sujeito de sua terra, a natal e a espiritual, e as terríveis e incuráveis consequências desta experiência que parece ter sido o símbolo de um tempo, a modernidade, marcado por conflitos, guerras e quebras de paradigmas, em que pese a sua existência trans-histórica e trans-temporal, na medida em que o drama do exílio parece ser marca da sociedade humana.

«QUEM MUITO VIU...»

Quem muito viu, sofreu, passou trabalhos, mágoas, humilhações, tristes surpresas;

e foi traído, e foi roubado, e foi privado em extremo da justiça justa; e andou terras e gentes, conheceu os mundos e submundos; e viveu dentro de si o amor de ter criado; quem tudo leu e amou, quem tudo foi-

não sabe nada, nem triunfar lhe cabe em sorte como a todos os que vivem. Apenas não viver lhe dava tudo.

Inquieto e franco, altivo e carinhoso, será sempre sem pátria. E a própria morte, quando o buscar, há-de encontrá-lo morto.

1961

(SENA, 2013, p. 485-6)

Nos poemas anteriormente citados e comentados, o sujeito poético se apresenta como aquele capaz de filtrar e poetizar as experiências selecionadas pelos sentidos. No poema acima, entretanto, o sujeito poético desloca a experiência poética para uma universalidade: afinal, quem é que $(\mathrm{m})$ muito viu? Ela, a voz do poema; Jorge de Sena, através de quem a voz do poema emerge (e vice-versa); ou um outro inatingível e inatingível porque toda a gente? "Quem muito viu" é a 
síntese arrebatadora de todos aqueles que passaram pela experiência do exílio, do afastamento geográfico de sua terra, é a síntese de quem muito "sofreu, passou trabalhos, / mágoas, humilhações, tristes surpresas;" portanto, de quem se sente e se sentiu exilado em solo pátrio antes mesmo de sair de lá.

O poema carrega em sua construção estilística vocábulos que acentuam um tom amargurado e eloquente à denúncia que ali é feita. De fato, o tom do poema resvala numa aguda denúncia que não poderia ser diferente já que a sua poética se identifica com o testemunho enquanto modelo de educação e, sobretudo, transformação do mundo. Nesse sentido, o poema é um exercício de ética poética plena ao correlacionar o sentimento de privação da terra, o berço original e espaço onde a vida é possível, Dardel (2011) disso falava, com uma morte um pouco mais grave que a morte física. Ora, se o sujeito foi "privado em estremo da justiça justa”, porque há justiças injustiças, na forma da lei, sobretudo em períodos de conturbação política como o são os de todas as ditaduras; se esse mesmo sujeito "andou terras e gentes, conheceu / os mundos e submundos;", à guisa de peregrinação, a morte física e corporal parece ser menos severa que a morte espiritual.

É curioso observar o caminho de gradação que é o quadro sentimental apresentado nos poemas de Jorge de Sena, ou seja, como se comporta o sujeito lírico, e em larga medida o próprio poeta, frente à terra de que parte, à terra a que chega e a terra a que chegará, porque esses sentimentos repousam numa atmosfera contrapontística que por vezes nega por completo um sentimento de afetuosidade positiva - seria amor? - à pátria que deixou, ou por vezes resvala num sentimento de amargura profunda, o leitor o sente bem, pelas injustiças por que passou lá, em sua terra. Ora, o sujeito trata a terra não como qualquer terra, mas como uma muito sua terra, de que a marca deixada pelo dêitico e pelo possessivo - "na minha terra" - afirma o pertencimento à uma terra, que não há, em "Os Paraísos Artificiais".

Num cântico à uma terra, que não há, e, por isso mesmo, tornado (anti)cântico, o sujeito lírico não associa explicitamente a categoria "terra" à de "pátria". Não há uma aproximação direta, mas possível de ser feita, na medida em que a paisagem ali descrita, um paraíso artificial, é absolutamente marcada por uma ausência de um Portugal que se revela cada vez mais distante do Portugal de sua infância, recuperado em fragmentos pelos desvãos da memória do poeta. Não há terra, e não há pátria, isso sentencia agudamente o sujeito "quem muito viu": "inquieto e franco, altivo e carinhoso, / será sempre sem pátria.” Sentença que, aliás, prepara o leitor para a explosão conceitual que se dará mais à frente, quando o sujeito, em diálogo de vida com o minotauro exilado, 
associa o conceito de nacionalidade e de pátria com o hábito de vestir e retirar camisas do corpo, com o devido respeito às camisas vestidas.

E não só, o poema agudiza o estado de espírito do "sem pátria”, quando nos seus dois últimos versos afirma que "E a própria morte, / quando o buscar, há-de encontra-lo morto". A pátria é a terra, e vice-versa, aqui no poema, o sentimento de estar apartado dela, num nível maior que o geográfico, o espiritual, acarreta uma consequência não menos pesada: a morte do espírito. Agora, já não cabe mais a figura da morte como aquela que arrebata a alma do moribundo que agoniza, porque ele já está morto, e nada resta. É um final de tom trágico, algo conformista, se bem que conformista não seria talvez palavra exata para se referir a um quadro sentimental revelador de um compromisso ético do poeta.

O poema de 1961 parece negar a premissa dum outro poema anterior, de 1956. Em “"Quem a tem...»", por exemplo, o poema afirmou um duplo pertencimento: ao mundo, cuja fidelidade pode ser sentida no decorrer de toda a sua obra; e a uma terra, aquela em que nasceu: “Eu não posso senão ser / desta terra em que nasci.". Mas ora, a negação se resume em aparência quando se observa que os dois poemas, os dois sentimentos, são frutos de uma perspectiva dialética de entendimento do mundo, e sobretudo, de uma perspectiva diferenciada dos modos pelos quais são possíveis pertencer a uma pátria em específico. A voz do narrativo "Em Creta, com o Minotauro" é enfática ao afirmar que nacionalidades são como camisas que se despem, logo, são e podem ser mutáveis, porque a pátria seniana, além-Portugal, pode repousar numa ideia mesmo diferenciada da própria categoria de pátria.

A essa altura seria pertinente perguntar novamente por um Brasil na fecunda peregrinação brasileira do poeta das Metamorfoses? Um Brasil que, assim como o seu "paraíso artificial" - e somente artificial porque irrecuperável, senão pela via da memória, falha - não há. A terra de que se falou, acima, o tempo todo longe está em ser identificada com o Brasil. As relações com esta terra desenham-se pela ausência, por outros caminhos, aqui destrinchados. Mas antes de "Em Creta, com o Minotauro”, a que sempre retomo pelas múltiplas potencialidades do poema, há, entretanto, uma glosa, a "Glosa de Guido Cavalcanti”, de que o tema do exílio é não só o mote, mas o corpo e o ar mesmo do poema, inscritos, poema a poema numa atmosfera de esperança desesperançada que é uma das marcas do sujeito poético do testemunho.

\section{GLOSA DE GUIDO CAVALCANTI}

«Perchi' I' no spero di tornar giammaì 
Porque não espero de jamais voltar à terra em que nasci; porque não espero, ainda que volte, de encontrá-la pronta a conhecer-me como agora sei

que eu a conheço; porque não espero sofrer saudades, ou perder a conta dos dias que vivi sem a lembrar; porque não espero nada, e morrerei no exílio sempre, mas fiel ao mundo, já que de outro nenhum morro exilado; porque não espero, do meu poço fundo,

olhar o céu e ver mais que azulado esse ar que ainda respiro, esse ar imundo por quantos que me ignoram respirado; porque não espero, espero contentado.

$$
11 / 6 / 1961
$$

(SENA, 2013, p. 488-9)

O poema de Jorge de Sena glosa um outro poema do italiano Guido Cavalcanti, cujo primeiro verso lhe serve de mote e ar - «Perchi' I' no spero di tornar giammaì - o título é já prenúncio. Poeta e grande representante do Dolce stil nuovo, junto de Dante Alighieri, Cavalcanti pertencia ao grupo social dos guelfos da nação da branca (i Bianchi), opostos aos guelfos da nação negra (i Neri). Numa Itália ainda não constituída enquanto nação, esses dois grupos lutavam entre si pela conquista de poder, e com o poeta stilnuovista não teria ocorrido diferente. De acordo com Pozenato (2016), consta que tenha nascido em Florença por volta (ou antes) de 1260, sete anos antes do término da batalha de Beneveto, cujas consequências trágicas às famílias florentinas as obrigou, num acordo de bilateral de paz, a casar membros dos partidos opostos.

Como aponta o estudioso, acerca desses arranjos familiares, "Guido, um guelfo, (então com menos de 12 anos de idade) se tornou noivo de Beatrice (Bice), filha do gibelino Farinata degli Uberti, e mais tarde casou com ela, tendo ao menos uma filha, Tancia, e um filho, Andrea." (POZENATO, 2016, p. 33). O poeta teve formação humanística que certamente serviu de base para a constituição de seu estilo e aderência ao "estilo novo", cujas características, de acordo com o crítico, poderiam ser sintetizadas em três esferas: o plano estilístico, o plano temático e o plano conceitual: 
A presença de imagens e metáforas, associadas a cenas da natureza e expressas em versos com musicalidade suave e bem desenhada, em que o cuidado com a seleção das rimas é visto como fundamental.

$\mathrm{O}$ amor como centro do mundo poético e a figura da mulher como deflagradora da experiência de um amor capaz de erguer o homem do mundo terreno para o celeste: nessa dialética.

A estreita relação entre a faculdade de amar e a nobreza de espírito, não por posição social, mas por virtude (...) a adoção de uma postura filosófica que valoriza a dimensão sensorial, na linha do averroísmo aristotélico: o platonismo agostiniano deixa de ser referência. (POZENATO, 2016, p. 34)

Descrito o acima, resta saber o que Guido Cavalcanti e sua glosa tem em comum com Jorge de Sena, posto não ser de modo aleatório que a referência ali aparece: o poeta stilnuovista, bem como os poetas anteriormente citados, à maneira de glosa ou em epígrafe, tais como Camões, Ruy Cinatti, dentre outros, experimentaram à sua maneira as vicissitudes do exílio. Dessa maneira o diálogo com eles proposto por Sena é construído de uma maneira poética e experiencial de onde é possível enxergar as duas experiências, a dele e a dos poetas com os quais dialoga, e ao mesmo tempo uma terceira, síntese universal. Guido, a exemplo, no período de recrudescimento das guerras entre guelfos brancos e negros, fora forçado a seguir em exílio em Sarzana, na Ligúria:

Com outros guelfos da facção branca, Guido foi exilado em Sarzana, na Ligúria, próximo a Gênova: exílio lembrado, ao que parece, na balada Perch'i' no spero di tornar giammai ("Porque não espero voltar jamais"). De Sarzana ele retornou a Florença, doente, provavelmente de malária (o nome da doença deriva, etimologicamente, de mala aria - maus ares...), onde morreu, sendo sepultado a 29 de agosto de 1300. (POZENATO, 2016, p. 33)

"Porque não espero voltar jamais" ou, senianamente, "Porque não espero de voltar jamais", o poema do italiano começa com esses versos que evocam a ideia de peregrinação com um tom de tragicidade: o sujeito não está em sua terra natal, está longe de tudo e de todos, sobretudo de sua amada, e à ela canta o verso inicial de crença na morte em exílio, na distância. O poema é longo e encerra outras questões, principalmente naquilo que ele carrega de semelhança e diferença com as cantigas do período produzidas nos outros territórios daquilo que mais tarde será a Europa. Mas ora, o poema de Sena trata de igual assunto, sem destinatário, sem amada, porque o seu poema tem como destino final o mundo mesmo do qual se alimenta.

Se, no poema de Guido Cavalcanti, o que sucede o verso trágico, nutrido da desesperança de retorno à pátria mãe, o que implica em não ver mais a sua amada, e isso é dor maior, o poema seniano é todo ele o canto desesperançado e amargurado de alguém que, distante de Portugal, sobre ele medita profundamente e professa sua fé no não retorno à uma terra que não estaria pronta a 
"conhecer-me como agora sei / que eu a conheço" de tensão entre o poeta e a sua terra natal, marcado acentuadamente pela presença do "porque" explicativo, como que em resposta a uma pergunta sempre em estado de suspensão, feita por não se sabe quem; e talvez até a si mesmo em suas inquietudes de saber-se irremediavelmente fraturado. O exílio é isso, afinal, e um desejo de volta à terra, ainda que inconfessável.

Curiosa a marcação explicativa que se dá logo depois da afirmação, "Porque não espero de jamais voltar / à terra em que nasci”, há aí uma certeza talvez enfraquecida pela metade do verso que a segue: "porque não espero,/ ainda que volte, (...)". Voltar à terra "em que nasci” é desejo marcado pelo saber de que o retorno é impossível, por duas razões: o poeta nos fala de Portugal, daquela terra de que sai pelas complicações da ditadura salazarista; ou seja, já é um Portugal impossível de se praticar a vida com todas as garantias de liberdade que ele tanto apreciava e defendia; e porque o afastamento geográfico, a bem ou mal, gera no sujeito uma série de movimentações internas que o obrigam a pensar sua terra natal de uma maneira diferenciada: Portugal já não será o mesmo, ainda que liberto das garras ditatoriais, e muito menos estará pronto para recebe-lo em seu "estrangeiramento" adquirido.

O poema, aliás, pode ser inserido naquele quadro de gradação sentimental que se observa no percorrer da obra seniana: da esperança à desesperança, e delas à uma desesperança esperançada (ou o oposto), e de uma recordação afetiva da terra natal à uma amargura em lembrar. No poema “《Quem a tem...»" de 1956, constituído cinco anos antes deste sobre o qual as análises prosseguem acima, o poeta demonstra uma certa esperança na medida em que afirma pela afirmativa negativa que: "Não hei de morrer sem saber / qual a cor da liberdade.” Enquanto afirmação forte de um sentimento genuíno, ela enfraquece em "«Quem muito viu...»”, na constatação de que "será sempre sem pátria”, reforçada na glosa, quando afirma que “(...) e morrerei // no exílio sempre, mas fiel ao mundo," ${ }^{46}$.

Curioso notar que o exílio brasileiro de Jorge de Sena só viria a acontecer três anos depois, em 1959, mas já ali ele nos fala dessa liberdade, da sua cor, a ele também desconhecida. Esta

\footnotetext{
${ }^{45}$ Este saber melhor da terra portuguesa, uma visão que o sujeito pode adquirir com a experiência do exílio, também encontra ecos em sua correspondência, aquela trocada com Sophia de Mello Breyner Andresen. Em carta escrita a $1^{\circ}$ de Março de 1963, três anos após a escritura de sua "Glosa a Guido Cavalcanti", o poeta escreveria: "As nossas saudade de vocês [de Sophia e de Francisco, seu marido] são imensas; do Portugal que suportam, não. Mas será que alguma vez teremos o Portugal que queremos? É evidente que eu não alterei em nada a minha posição, nem a minha firmeza. Apenas cada vez melhor vejo as engrenagens da política, e desespero da incompetência que vejo mais generalizada e prestigiosa." (Jorge de Sena) [Grifos meus]

${ }^{46}$ Esta ideia, ou mesmo aceitação trágica, do exílio como único destino possível, como o destino do poeta, ecoa, novamente, em carta a Sophia de Mello. A glosa inscreve esse sentimento trágico em 1961, e na carta de 12 de Julho 1964, escrita em solo brasileiro (Araraquara), o poeta reafirma: "Já me resignei (se é que não prefiro) ao exílio mais ou menos permanente; mas só desejo um país em que não se fale a nossa língua, para não assistir pessoalmente à degradação dela, que cada vez menos tenho ânimo de suportar." (Jorge de Sena)
} 
primeira estrofe do poema, forte em essência e posicionamento ético, ilustra, junto de outros poemas, o sentimento de “estrangeiramento" em solo pátrio, o insílio tão marcado no ser do poeta, sobretudo porque ele tem plena consciência de que "Eu não posso senão ser / desta terra em que nasci”, no estabelecimento de um pertencimento duplo e possível ao mundo e a Portugal. Qual a cor da liberdade para o poeta, soube ele algum dia? De regresso à sua glosa, em seu terceiro "porque" - no total são seis - ele nos fala da saudade, sentimento de larga tradição na lírica portuguesa, mas por ele rejeitado, não enquanto sentimento próprio de uma identidade portuguesa, do qual não poderia escapar, mas enquanto motivo lírico fecundador de sua poesia.

Jorge de Sena opta por outro sentimento: o da amargura, e aí a sua poesia ganha outros contornos e complexidades, porque é um sentimento situado entre dois espaços, o da terra pátria e o da terra de chegada, como bem apontou Sílvio Renato Jorge, no seu "Jorge de Sena, um poeta sem fronteiras", ensaio no qual trata do alcance da poesia seniana. Para o crítico e estudioso, com o qual concordo, a poesia de Jorge de Sena não se alimentaria de um sentimento por esta ou aquela pátria, a de partida ou a de chegada - mãe e madrasta, numa leitura algo psicanalítica que bebe da fonte de Julia Kristeva -; o motor de sua poesia é o próprio sentimento de "ausência" ou "falta", de incompletude, tornado objeto poético, opção potencializadora de um sentimento de fratura ainda pior que aqueles impostos por motivações tradicionalmente a ela associadas:

É acerca do lugar ambíguo entre o desejo e a repulsa, dessa memória, a Camões, deliciosamente magoada, que estou a refletir. Ou seja: interessa valorizar a antítese que dá forma ao modo como o exilado busca situar-se entre dois espaços, reflexo da nostalgia que, ao invés de dirigir-se a qualquer uma das pátrias com que se vê em diálogo - a mãe displicente e a madrasta nem sempre acolhedora -, opta por tomar o seu próprio sentimento de ausência e de falta como objeto poético por excelência. Nesse sentido, o que percebemos é a ênfase em um exílio mais profundo do que o imposto por contingências políticas diversas, exílio este capaz de levar o indivíduo a sentir-se estrangeiro em qualquer parte, por não reconhecer no outro o espelho próprio para refletir as distintas marcas de seu rosto. (JORGE, 2006, p. 111)

Este sentimento, inscrito numa temporalidade e surgido como seu efeito colateral, bem como os outros sentimentos e expressões entendidos na esteira de Eduardo Lourenço, seriam sentimentos entendidos na dimensão temporal que enforma a Peregrinatio de Jorge de Sena. Ora, o título do livro feito diário poético é evocativo nesse sentido: Peregrinatio ad Loca Infecta evoca uma dimensão temporal circunscrita no ato em curso de uma peregrinação, feita por entre lugares absolutamente infectos, naquele entendimento seniano do que seria algo infecto, portanto, profundo e crítico. O título do livro mesmo suscita o entrelaçamento entre tempo e espaço, cuja síntese resvala numa postura algo original e profícua acerca do mundo que circunda o poeta. Atente-se, aliás, à palavra peregrinação. 
De acordo com Lima (2003), teria sido por volta de 1394, ano do nascimento do Infante Dom Henrique, que começa a aparecer em língua portuguesa uma palavra para designar a experiência de "viagem", sobretudo aquelas de cunho e orientação religiosa. Assim seria introduzido o vocábulo "romaria", cujo sucesso seria marginal e fugaz, em detrimento da existência de um outro vocábulo que melhor designava a experiência de trânsito e partida vivida pelos povos naquele período. O vocábulo "viagem", do latim provençal, estava dessa forma inserido no imaginário linguístico português desde o século 11 ou 12, pelo menos, ombreando-se conceitualmente a "caminho", "carreira", "via" e "jornada"

"Viage", do latim "viaticum", restringia seu campo semântico não tanto ao percurso ou jornada de trânsito entre terras, mas ao que se leva, no caminho, para o sustento dos partícipes ou o enfrentamento de adversidades outras que pudessem interferir na jornada trilhada. É uma concepção que se diferencia, portanto, de um conceito mais popular de viagem naquela ideia de deslocamento geográfico ou de viagem por terra, conceito que só começará a ser difundido por volta do século 16, com a popularização, no reino português e espanhol, das viagens transoceânicas, que resguardavam em si mesmas a ideia de preparo anterior e, portanto, de saber técnico e de uma especialização para enfrentamento dos mares porvir.

Somente no século 17 é que, no entanto, há uma predominância do vocábulo “peregrinação" em detrimento de "itinerário”. É importante destacar, aliás, que já no século 16, à época das Grandes Navegações, "peregrinação”, "era a palavra mais popular para designar uma longa viagem e suas implicações. Tão popular que relegou itinerário praticamente ao título de relato.” (LIMA, 2003, 112). Isso se deveu, claro, por dois motivos claros que o estudioso sintetiza como sendo: a ideia proposta por "peregrinação": "exprimia a idéia de imersão no estrangeiro absoluto, por um lado, e enfatizava, por outro, um significado de fundo religioso, bem a gosto daquele século tão temente a Deus.” LIMA, 2003, p. 112). Peregrinar é, portanto, sair de sua terra natal ou da terra em que se vive, em busca de um estrangeiro, duma outra terra, e nela imergir profundamente.

A peregrinação não é, contudo, uma romaria, vocábulo inscrito no léxico português somente no século 13, enquanto aquele tem em "pelegrinagee", cujo primeiro registro se dá no ano de 1440, segundo Pedro Machado (1990), seu ancestral remoto. Peregrinação e romaria podem ser semanticamente aproximados, mas resguardam diferenças profundas:

Romaria e peregrinação, por conseguinte, estão separadas pela estranheza da terra. A primeira é uma simples viagem a um lugar santo, sem nada que desvie a atenção do viajante entre o ponto de partida e o de chegada. O caminho é tão somente um pequeno obstáculo que separa o romeiro de seu desejo. 
Ao contrário da primeira, a segunda tem como definitivo apenas o ponto de partida, porque entre este e o de chegada há uma tão grande quantidade de desvios que por vezes ofuscam completamente o último, como bem se pode ver no sentido que Morais lhe atribui na definição e romaria. Se há uma peregrinação religiosa, é porque há uma outra que não o é ou não precisa ser, embora o terreno esteja sempre carregado de religiosidade no senso comum. Em outras palavras, a romaria é sempre uma peregrinação religiosa, mas nem toda peregrinação é necessariamente uma romaria. (LIMA, 2003, p. 113)

E o que seria, então, a peregrinação? O estudioso responde:

A peregrinação é a viagem mais complexa e multifacetada de todas elas, porque soma nela mesma, curiosidade, técnica, religiosidade, capacidade de observar, de analisar, de comparar e de registrar o observado. Tudo isso envolvido num ardente desejo de confrontar prazerosamente o estranho. Por isso é que o século XVI precisou tanto dela, e tanto utilizou essa palavra. (LIMA, 2003, p. 114)

Ora, se por um lado, ao adentrar a seção "Brasil", de que me ocupo neste ensaio, o leitor depara-se, e, possivelmente, estranha uma ausência da configuração de um panorama brasileiro, na medida em que o Brasil ali figura num total de dois poemas, aqui analisados, não é verdade que a estadia seniana aqui tenha repousado num absoluto silêncio de tudo: a terra brasileira, na poesia de exílio de Jorge de Sena, surge curiosamente pelas fendas, talvez as mesmas daquela catedral aquática e sonora, cujo som fora há muito interrompido pela queda do vaso chinês; surge num espaço intervalar e de "entre-distância" ${ }^{47}$, a sedimentar uma relação do poeta com o Brasil que é tão curiosa quanto a que ele tem com a sua terra pátria.

É curiosa numa outra configuração e diferente da pátria mãe, posto que é na ausência de uma paisagem brasileira que se dá e se reafirma o lugar de Portugal em sua vida e em sua poesia, mas, ainda assim, curiosa, sobretudo porque instiga o ser do poeta ao exercício do amar: amar amarguradamente uma terra simultaneamente próxima e distante, o Brasil. É possível ser-se português, o que quer que isso signifique no caso de Sena, e sobretudo no dele, em terras distantes, em terras que jamais serão $l a r^{48}$ para si? A pergunta, meio horaciana, meio seniana, resguarda uma infinitude de possíveis respostas, talvez nenhuma delas satisfatórias para justificar o drama do desterro, mas fato é que, se na poesia o Brasil fica ausente e Portugal aparece, nas cartas trocadas

\footnotetext{
47 Referência ao poema "Entre-Distância", publicado no livro Fidelidade (1950), onde o sujeito poético elabora reflexão sobre a criação de um espaço afetivo concretizado na ausência física entre dois sujeitos.

48 A associação que faço aqui entre terra de aconchego e lar repousa na reflexão conceitual de Yi-Fu Tuan acerca das significações em torno do lugar, ou seja, o entendimento do lugar, em oposição antitética ao espaço, como resguardo e segurança, como lar. Estas reflexões podem sem encontradas em Topofilia (2012) e em Espaço e Lugar (2013) - onde são reforçadas - ambos reeditados recentemente pela Editora da Universidade Estadual de Londrina (EDUEL), sob os cuidados de sua primeira tradutora para o português, a Professora Doutora Lívia de Oliveira.
} 
com a sua muito amiga, e poeta, Sophia de Mello Breyner Andresen, o Brasil é não só tema de longas cartas, mas uma presença constante.

Jorge de Sena e Sophia de Mello Breyner Andresen mantiveram ao longo de toda a vida uma amizade baseada em profundo afeto e respeito mútuo a obra de cada um deles. Cito alguns trechos das correspondências ${ }^{49}$ que trocaram, sobretudo aquelas escritas no período brasileiro do poeta, porque apontam, no que tem de confissão biográfica, para questões interessantes levantadas nesta dissertação. Não se trata, por ventura, de explicar a obra poética pelo espaço epistolar, mas do entendimento de que há um entrecruzamento entre testemunho poético e confissão bastante peculiar que merece ser destacado. Se o Brasil é ausência, na poesia, e isso diz muito sobre o poeta e sua relação com o Brasil, o país é tema frequente em sua correspondência afetuosa com a amiga poeta. Trago, portanto, alguns trechos desta correspondência para por em evidência a relação de Jorge de Sena com o Brasil e servem de eixo comparativo em relação aos poemas e o que carregam de Brasil, se bem que muito pouco.

Carta de Jorge de Sena à Sophia de Mello, em 20 de Dezembro de 1962 (Araraquara - São Paulo):

Cada vez mais penso que Portugal não precisa de ser salvo, porque estará sempre perdido como merece. Nós todos é que precisamos que nos salvem dele. Mas sabe que não há maneira fácil? Eu, por exemplo, tenho feito por comportar-me como brasileiro em tudo, o que a minha vida oficial me impõe aqui: eu sou funcionário do Estado, assessor do Ministério da Educação (constará aí que se me deve que a Literatura Portuguesa seja obrigatória em todos os cursos superiores de Letras?), figura pública de mérito reconhecido. Isto sem abdicar em nada de ser português que ninguém é mais do que eu. Pois só consigo ser suspeito a todo o mundo: aos "exilados", porque me abrasileirei, quando eles se recusam a tomar conhecimento do país em que vivem e do que vivem; e aos brasileiros (não aos meus amigos, é claro), porque sou um agente temivel da "portugalidade"... (Correspondência, Sophia de Mello Breyner Andresen, 2006, pp. 52-53) [Grifos meus]

Atente-se para os trechos grifados. Eles apontam para, pelo menos, dois elementos importantes para a reflexão que aqui tentou ser desenvolvida: há, na carta, a imagem sempre presente e viva de Portugal, aquele país a que o poeta pertence inegavelmente e, como dito no início deste ensaio, talvez de modo excessivo. A ideia mesma de salvação daquele país causa certo desespero em quem o lê, porque aponta para a difícil situação política que permeia a vida de toda a gente na terra portuguesa. O poeta sabe muito bem que "Não hei-de de morrer sem saber qual a

${ }^{49}$ Estas correspondências podem ser encontradas no volume Sophia de Mello Breyner \& Jorge de Sena: Correspondência (1959-1978), editado pela viúva do poeta, Mécia de Sena. 
cor da liberdade", mas da ditadura salazarista até à "cor da liberdade" houve chão. E no intermédio: um abrasileiramento, dele (do poeta), muito mal visto dos dois lados do Atlântico.

Para os portugueses, a exceção de seus amigos, o poeta frisa, já não era mais português, porque brasileiro naturalizado. Para os brasileiros, um não-brasileiro, porque, brasileiro naturalizado; e, antes de tudo, português. Há um conflito aí que o poeta sente em alguma medida, disso o trecho destacado da carta dá conta, e não só, na medida em que são sentimentos algo antitéticos e confusos que irão aparecer em sua poética ${ }^{50}$. Por isso mesmo, a alusão a esses trechos não são confirmação biográfica daquilo que aparece na poesia, mas a observação da permanência de um sentimento tão forte nos diversos níveis de expressão artística de Sena. A relação do poeta com o Brasil e, pois, a impressão brasileira inscrita numa visão portuguesa talvez passe por esta trilha sinuosa, mas profícua.

Talvez seja por este caminho sinuoso, ou seja, aquele que considera a dimensão profunda de um exílio algo espiritual, na medida em que aqui a inserção da "terra", mãe e madrasta, já está superada, o caminho possível para se entender o jogo dialético entre presença e ausência em relação a Portugal e aos demais espaços de exílio, proposto no âmago da poesia seniana. Entretanto, no que se refere ao Brasil, a questão tende a se tornar densa, e alguns motivos podem ser elencados: Brasil e Portugal tem uma relação inevitável e histórica, inscrita no imbróglio do descobrimento. Brasil é a terra filha da nação portuguesa, mãe, mas cujos pais variam, dada a multiplicidade de influências e povos que aqui aportaram e contribuíram para a constituição de uma terra brasileira, independente da (ex)metrópole somente no século XIX.

Qual a posição do poeta e intelectual Jorge de Sena frente a esta terra, a brasileira, de língua aparentemente igual à de sua terra pátria? A resposta teria que passar por questões que envolvem as próprias relações luso-brasileiras, para localizar o lugar do seu discurso. Mas o fato é que, se o exílio é destino peremptório na vida do poeta, "porque não espero nada, e morrerei // no exílio sempre, mas fiel ao mundo, / já que de outro nenhum morro exilado", esta condição, a da partida eterna, o desloca para uma posição incômoda, a coadunar com o incômodo de ser por questão ética uma eterna testemunha (do mundo), mas frutífera de poder perceber criticamente tanto a pátria de nascença quanto as terras de chegadas. É a partir deste olhar, o olhar da "ave nocturna",

\footnotetext{
50 Observe-se que o poema integra a seção IV do emblemático Exorcismos (1972). Publicado logo após a sua Peregrinatio, este livro traz poemas ainda sob forte influência da circunstancialidade do exílio. A epígrafe desta quarta parte, reputada à Tomás Ribeiro, de quem se lê, "Meu Portugal, meu berço de inocente", não poderia ser menos coerente ao conteúdo que se lê em outros poemas de Jorge de Sena. Em específico, e a culminar nessa ideia do não reconhecimento de sua dupla-nacionalidade, por portugueses e brasileiros, figura o poema "O ecumenismo lusitano ou a dupla nacionalidade". Cf. Anexo D (poema na íntegra)
} 
atento e vigilante, que o sujeito poético e o poeta debruçam-se por sobre as entranhas das terras pelas quais peregrinou. Retomo:

\section{$[\ldots]$}

porque não espero, do meu poço fundo, olhar o céu e ver mais que azulado esse ar que ainda respiro, esse ar imundo por quantos que me ignoram respirado; porque não espero, espero contentado.

$$
11 / 6 / 1961
$$

(SENA, 2013, p. 488-9)

Aliás, aquilo que é uma visão crítica do mundo, em Jorge de Sena, poderia ser dito de outra maneira, de uma perspectiva bem mais seniana: é uma visão infecta do mundo, e por que não da própria vida, aquela inscrita numa poesia que não trata de belezas retóricas ou de motivos artificiais, a não ser para criticá-los acidamente; uma poesia que repele por princípio o conluio entre poetas, à maneira de "inspecionarem" uns as "chagas" dos outros. Jorge de Sena inspeciona chagas, todos os poetas em algum nível o fazem, mas opta por inspecionar as chagas do mundo e da vida, num movimento de respeito e cuidado com aquilo que é o fora de si que torna a sua consciência de mundo bastante peculiar. Talvez por isso o seu "dedo" seja "sujo", porque não poderia haver outra coisa no interior de uma chaga, como disse no poema a seguir, de sua Perseguição (1942):

\section{LEPRA}

A poesia tão igual a uma lepra!

E os poetas na leprosaria

vão vivendo uns com os outros, inspeccionando as chagas uns dos outros.

$$
(3 / 7 / 1939)
$$

(SENA, 2013, p. 46) 
Lepra, chagas, poesia, "dedo sujo" e, além ou no espaço intervalar de "ar imundo", a peregrinação. O caso de Jorge de Sena é particular até nesse sentido. A peregrinação seniana, infecta, está inscrita num espaço de "entre-distância”: se uma peregrinação pressupõe, como ficou dito anteriormente, "curiosidade", "técnica", "capacidade de observar", "de comparar e de registrar o observado", num desejo final que culmina no "estranho", no lugar outro que não o lugar de partida, em Sena, na seção em que a ele seria permitido isso realizar - a grande imagem do Brasil, ou uma imagem infecta do Brasil -, ao intento se nega. A peregrinação seniana, no que compete às paisagens brasileiras, é uma peregrinação às avessas, porque mira com pouco alcance a terra de chegada, o absolutamente outro.

Não há Brasil, há Portugal. Por isso, se é verdade que o poeta assume a postura de negação de sua terra natal, em detrimento da afirmação de um sentimento saudoso, pela via da nostalgia, menos que da melancolia, como disse o crítico Sílvio Renato Jorge, esta negação jamais se realizará pela ausência escrita de um Portugal que, a despeito de tudo e de todos, foi sempre presença viva e confusa na poesia de Jorge de Sena, antes e durante sua experiência de exílio, sua vida toda. Há um desejo e uma presença de Portugal que chega a doer, por vezes, de tão marcado é o aparecimento daquela terra. E é nesses aparecimentos constantes que as demais paisagens exílicas - se bem que especificamente a brasileira; a americana é outro caso - figuram em sombra, poeticamente.

Ou seria mesmo parcialmente às avessas, se se leva somente em consideração a produção poética em que seria possível rastrear um sentimento profundo em relação à terra brasileira. No que se refere às cartas que trocou com Sophia de Mello Breyner Andresen, fica evidente a sua (anti)empolgação e consciência do nascimento de um amor amargurado ao Brasil:

\section{Carta de Jorge de Sena à Sophia de Mello, em 12 de Julho de 1964 (Araraquara-São Paulo)}

Como thes invejo essas viagens que tem podido fazer! E tanto mais, quanto a minha desilusão momentânea (um momento que pode durar) com o Brasil é total (e já vinha sendo), e não desejamos, eu e a Mécia, outra coisa que não sair daqui. Mas para onde? Eu não quero perder as possibilidades de pesquisa e de trabalho, que o ensino de literatura me dá. E essas possibilidades estão sempre à mercê dos que têm por trás os governos e os favores que podem assim comerciar. No entanto, muitos amigos, por esse mundo afora, se preocuparam com o que se possa ser aqui o destino de um espírito livre; e talvez que consigamos partir mas não já: México ou Estados Unidos? Não sei dizer-lhe ainda. A Europa parece mais difícil, porque [...] (Jorge de Sena)

O Brasil - que nunca foi fácil... tornou-se extremamente difícil, de uma insegurança que faz esse país portugalino parecer brincadeira de crianças. 
Brincadeira a que não acho graça, e a que não tencionamos voltar por agora. E não me parece que, em condições de permanência, eu volte alguma vez: [...] (Correspondência, Sophia de Mello Breyner Andresen, 2006, pp. 70-71)

É na carta de 21 de Maio de 1966, escrita em Madison (Wisconsin), nos Estados Unidos, país em que passaria a viver em caráter definitivo somente em 1965, que vem a declaração assertiva sobre o sentimento do poeta pelo Brasil. Apesar de tudo, e da sua impossibilidade de aqui permanecer, as razões da partida foram de várias ordens: Sena, durante sua estadia no Brasil, já tinha uma família numerosa e era grande o esforço para sustenta-la. Para além, a situação política em solo brasileiro já era de uma instabilidade perigosa, com a deflagração do Golpe Militar em 1964. Esta situação, sobretudo, força o poeta a sair do Brasil e buscar o seu exílio derradeiro, o americano, sobre o qual falarei adiante. À carta:

\section{Carta de Jorge de Sena à Sophia de Mello, em 21 de Maio de 1966 (Madison-Wisconsin-USA)}

E por quanto tempo aqui estarei? Ao Brasil, que amo, não pretendo voltar, porque é-me impossível sustentar lá uma família como a minha. A Portugal só quando for possível, e nunca para que pareça que pretendo pescar uma cátedra que ninguém me dará. No entanto, não creio que a América me prensa. [...] (Correspondência, Sophia de Mello Breyner Andresen, 2006, pp. 85)

todos:

Ou, à guisa de reafirmar seu amor infeliz e desencantado pelo Brasil, apesar de tudo e de

\section{Carta de Jorge de Sena à Sophia de Mello, em 30 de Agosto de 1966 (Madison-Wisconsin-USA)}

Eu tenho seis anos daquele país que amo, com um amor muito infeliz. (Correspondência, Sophia de Mello Breyner Andresen, 2006, p. 90)

Ou de sua possibilidade. Isso, apesar de tudo e de todas as vicissitudes em torno do ambiente universitário que haveria de passar, e não foram poucas ${ }^{51}$. Para o poeta, o testemunho é

\footnotetext{
51 Estas inconveniências acadêmicas dizem respeito, a exemplo, do imbróglio em relação ao seu exame de LivreDocência, que deveria ter ocorrido na Universidade Federal de Minas Gerais e não houve. E, também, à sua relação estranhada com Soares Amora, Massaud Moisés, dentre outros. A carta de 21 de Maio de 1966, escrita em Madinson (EUA) comenta esses episódios: “Em São Paulo, não sei se terá visto o mavioso Instituto de Estudos Portugueses, em que pontifica a mais terrível serpente luso-brasileira que é o Soares Amora, meu sinistro compadre, acolitado por um monumento de suficiência e malignidade turca que é o Massaud (à árabe e não à francesa, como ele prefere que se
} 
ético em sua função transformadora do mundo e da vida - aspectos que ganharão melhor forma no ensaio seguinte. Foi justamente pela constante ausência de Brasil que o Brasil se forma, ou não forma, na poesia seniana. À esta altura, seria válido já apontar para a constituição de uma paisagem da ausência, inscrita no quadro dialético do testemunho poético, de que os poemas aqui analisados dão farta notícia.

Assim como o sintagma seniano "dedo sujo", que engendra um movimento profícuo de abertura dupla, posto que permite pensar o Portugal do passado de Camões - e o Portugal do tempo de Sena -, e, além, no futuro metaforizado em Creta, o lugar mítico onde tomará café junto do Minotauro, os poemas aqui enfatizam a urgência do dizer, na forma da poesia, do mundo e do outro, e, portanto, de si mesmo. O testemunho é, portanto, necessidade, urgência viva na escrita poética de um poeta profundamente consciente de seu ser e estar no mundo como sujeito histórico e, pois, de seu tempo

diga...) também Moisés. É uma gente que nunca fez senão a própria carreira e a dos afilhados à custa da literatura portuguesa, como espero que a sua sensibilidade já terá entendido.” (Jorge de Sena, p. 86) 


\section{3 - JORGE DE SENA E OS E.U.A: REGRESSO ÀS PAISAGENS EUROPÉIAS}

Das relações confusas e tênues entre Jorge de Sena e a sua terra pátria, por ele identificada como madrasta, ou seja: a evidência de um amor perfilhado, dado por certa obrigação a um filho cujos laços de sangue são inexistentes. Dessa relação, ficou dito nos ensaios anteriores. Sobre o Brasil, pátria a que amou com um amor infeliz, amargo, como o amor a seu Portugal distante, parece estar claro seu exílio brasileiro. Contudo, a peregrinação seniana não acaba ali, na medida em que encontra nos Estados Unidos da América o seu destino último e derradeiro. O poeta, português de tudo, haveria de morrer em solo americano, cidadão americano com prole também americana. Ora, do que se viu no ensaio anterior, fica um sabor de Brasil, no testemunho seniano, marcado pela ausência.

Uma ausência marcada, é importante asseverar, por uma mágoa e uma desilusão, “desilusão momentânea (um momento que pode durar)", o poeta confessava num dos trechos da correspondência que trocou com Sophia Andresen. É uma desilusão que beirou a mágoa, a mesma com que penetrou fundo a sua portugalidade. Seria correto pensar, a esta altura, que as relações do poeta com o solo americano são também marcadas por essa afetividade potente, mas frustrada? Ao que parece, uma primeira resposta seria não, na medida em que, contrariamente ao que ocorre na seção "Brasil”, feita de ausência, a seção "Estados Unidos da América" parece oferecer alguns rastros de paisagem, de modo a ser possível vislumbrar o cenário com que o sujeito poético se funde, ou não, poema a poema de sua peregrinação última.

Entretanto, é preciso verificar esses rastros de paisagem, sobretudo porque o aparecimento de paisagens americanas, em detrimento de uma ausência das paisagens brasileiras, pode, tal como lá, significar muito além do que uma adesão fácil e tranquila a um modo de vida americano. A epígrafe, de lastro inglês, isso já se comentou, orienta de certa maneira a leitura empreendida dos poemas. Ao chegar ao fim da seção, os versos de Yeats ganham potência dialogante com os poemas de que são abertura e ponte. Há uma evidência de tempo, do Tempo, que passa e que marca ou marcou a juventude e o processo de envelhecimento do sujeito, marcado pelo "cio" e pela "raiva", tal qual Jorge de Sena e o seu Portugal.

\section{Epígrafe}

You think it horrible that lust and rage 
Should dance attention upon my old age;

They were not such a plague when I was young;

What else have I to spur me into song?

(Acham horrível que este cio e raiva sejam que atento dança o meu envelhecer; não eram uma tal praga em minha juventude. que mais eu tenho que a cantar me pique?) Yeats - The Spur

Yeats finaliza: "What else have I to spur me into song?" / Que mais eu tenho que a cantar me pique?”. Que mais haveria o poeta em sua peregrinação cantar? Que mais haveria de instigar sua verve cantante, nesse fluxo temporal que anuncia o seu envelhecimento? A resposta, seniana, parece ser encontrada em poema anterior, na seção anterior já antecipando o exílio último, não aquele em Creta, porque o poeta jamais esqueceu tudo, como aventou nos versos do seu poema "Mas, se um dia me esquecer de tudo, / espero envelhecer / tomando café em Creta / com o Minotauro, / sob o olhar de deuses sem vergonha”. A faculdade do esquecimento e a sua relação com a memória, surgida no poema, aprofunda-se na seção americana de sua peregrinação infecta, na medida em que ali o poeta há de meditar, quase poema a poema, acerca do tempo e de suas marcas inscritas num corpo que é o seu próprio.

Que se ouça, então, este último anti-cântico de sua peregrinação infecta, iniciado já com a marca precisa do deslocamento geográfico, promovido por um novo exílio, e evocado pelo título do poema, marca indicadora da mudança do Brasil aos Estados Unidos: "Do Trópico de Capricórnio aos Grandes Lagos” abre a seção americana de seu diário infecto, estabelecendo desde já um espaço criativo de formação mental e poética de uma paisagem americana, a partir da passagem das estações do ano, indicando a materialidade do fluxo temporal. A mudança das estações do ano, tão marcadas no seu novo lar infecto, são indício de mudança no tempo, em si, e no dos outros, com quem dialoga. Por fim, em si mesmo.

A poesia será soberana, por isso, que se leia:

\section{DO TRÓPICO DE CAPRICÓRNIO AOS GRANDES LAGOS}

Deste Outono em árvores despidas que em mil ramículos cruzados o livor enredam celeste e nevoento de que as águas tão crespamente se embranquecem frias, eu não sabia já. Envelhecia 
num Verão chuvoso ou num Inverno claro em que de noutras árvores a folhagem viva apenas de ser verde persistia.

Agora não. Neste hirto esbracejar de tantos dedos que o ar sem unhas cortam tão tranquilos, melhor hei-de saber que o tempo passa em que sou eu quem passa como tempo neste ficar do mundo, sempre renovado, com que da nossa vida é feito o tempo alheio.

$4 / 12 / 1965$

(SENA, 2013, p. 527)

O poema parece ser somente a descrição de uma paisagem vista ou sentida pelo sujeito de maneira com que a ela não se imiscui. Esta sensação advém talvez da mudança brusca de registro operada já no início desta seção. Basta que se lembre, por exemplo, que, a despeito de os "poemas brasileiros" não operarem a construção de uma paisagem brasileira, eles são, contudo, em diversas maneiras, combativos, de tom e ritmo severos. O próprio "Em Creta, com o Minotauro", que aparentemente resguarda algo de pacificação no espírito do poeta, é enganoso, na medida em que a sua construção se dá em tom de manifesto poético acerca das circunstâncias de exílio. A seção americana, entretanto, inicia com a apresentação de uma paisagem sóbria, cujo trânsito poderia passar despercebido, não fosse a dimensão transformadora operada pelos sentidos.

E por entre as imagens de "árvores despidas" de um "Outono" ou "Verão chuvoso" e num "Inverno claro" reaparece a imagem dos "dedos" - "tantos dedos" - que, num procedimento tipicamente seniano, cortam o ar, ainda que sejam dedos sem unhas. Não me parece que é o mesmo “dedo sujo", tão marcado de vivência e vidência na poética seniana, mas o próprio corpo, em sua porção, dando conta da materialidade fugaz e, por isso, apavorante, do tempo, "neste ficar do mundo, / sempre renovado, / com que da nossa vida é feito o tempo alheio." Uma visão quase esperançosa, a de um mundo sempre renovado, pelo qual o sujeito também passa em novidade, e sempre, o outro em seu compromisso ético.

As imagens principais evocam a situação de uma dupla transição, de que o poema é feito: a primeira de ordem espacial; a segunda de ordem temporal. Essa dupla dimensão aparece marcada durante toda a seção, e em especial no poema seguinte, cuja imagem repousa numa associação do adjetivo "frígido" ao vento, que passa e é sinal da passagem do tempo, igualmente ao poema anterior. Parece tratar-se de um poema sazonal, e, creio, a dinâmica da paisagem em sua faceta de enlace entre um sujeito e o espaço circundante é muito mais presente através das marcas que este mesmo frígido vento deixa no corpo do sujeito, e não retorna jamais. Ou seja, a experiência vivida 
anteriormente jamais retorna, jamais se repete, ainda que as circunstâncias que a ela sejam associadas, pareçam ser as mesmas. De mesmo ano do anterior, 1965, o poema retoma imagens e ideias daquele.

\title{
«FRÍGIDO VENTO»
}

\author{
Frígido vento \\ que não retorna \\ ah que saudades tenho de ser jovem \\ quando como ele \\ passava gélido \\ queimando as faces \\ crestando as mãos \\ deixando em corpos \\ algo de mim \\ sem que ficasse \\ nem lá nem cá \\ menos de mim \\ ah que saudades \\ tenho de ter \\ sido como ele \\ o jovem que talvez será memória \\ nos corpos em que o foi, como eles são \\ no meu memória de que o não sou mais.
}

Frígido vento
que só retorna
triste por tépido
por doce e flácido
por ténue e plácido
por quente ou frio
mas nunca mais
gélido vento
queimando as faces
crestando as mãos
deixando-as sujas
de intimidade
despudorada, anónima e feliz.

$4 / 12 / 1965$

(SENA, 2013, p. 528)

Há um desejo melancólico de ser-se jovem novamente, advindo da passagem do vento que é memória - "ah que saudades tenho de ser jovem" - de um tempo que jamais retorna. O sujeito percebe seu envelhecimento através da percepção deste mesmo frio, que assume, pelo título e o 
corpo do poema confirma, um tom erótico não usual, afinal "frígido" 52 não seria um termo usual para a descrição de uma sensação térmica. Se fica a imagem dos "dedos" sem unhas, cortados pelo ar, no poema anterior, aqui, há um entrelaçamento de corpos, numa troca quase alquímica em que, “deixando em corpos / algo de mim / sem que ficasse / nem lá nem cá / menos de mim”, ou seja, num espaço intervalar entre dois espaços indistintos, onde a memória parece se encontrar.

O sujeito poético deseja, então, ter sido ou ser como o "frígido vento" - ah que saudades tenho de ter / sido como ele - ou seja, como o vento, indício de memória e marca. Entretanto, ele tem consciência da impossibilidade de sua realização, pelo que marca a expressão com a metáfora. O mesmo vento, aliás, quando retorna, retorna "triste por tépido / por doce e flácido / por ténue e plácido / por quente ou frio", não mais o mesmo vento da juventude anunciada, e, ainda mais grave, "mas nunca mais / gélido vento / queimando as faces / crestando as mãos / deixando-as sujas / de intimidade / despudorada, anónima e feliz." (grifos meus). Ora, de novo e sempre, a “sujidão" aparece na poesia de Jorge de Sena; aqui, não propriamente pelo dedo, mas pelas mãos.

E é pela "sujidão" que este poema conecta-se ao central "Em Creta, com o Minotauro", se se tem em mente que o "dedo sujo", imagem-síntese surgida na segunda parte do poema, resultado da certeza (do sujeito poético) de que o Minotauro o compreenderá: ambos foram exilados, ambos foram incompreendidos. E de tomar o seu café, proveniente de destino algum reconhecível - a negar, uma vez mais, o estabelecimento de nacionalidades - resultará o "dedo sujo", com que mexerá o açúcar em chávenas cheias, para ele e para o seu companheiro de destino. A “sujidão" é produto, então, da perscrutação atenta às origens da vida, da própria vida do poeta, porque a sua vida foi sempre devotada ao papel de testemunha.

Dessas investigações das origens da vida, certamente, encontra-se a dimensão corporal e erótica do sujeito, na medida em que a "sujidão" reaparece no "Frígido vento" como sinal de feliz intimidade da entrega entre corpos. É o vento, entretanto, que dá sinais de que essas mãos não serão mais “sujas” do despudor, "anónima e feliz”, que não há mais. O poema é, nesse sentido, espacialmente intervalar, no que não há marcadores que dão a garantia da localização da paisagem criada. No anterior, é possível perceber marcas precisas de espaços potencialmente identificados com a paisagem americana, aqui não. De fato, a paisagem aqui avulta muito mais como coisa adentrada a apontar para o que mais importa: a passagem do tempo.

\footnotetext{
${ }^{52}$ De acordo com o Dicionário Priberam (Online), o vocábulo "frígido" (do latim frigidus -a, -um) significa: 1. Muito frio: álgido, gelado regelado; 2. Apático, indiferente; ou 3. Que não demonstra desejo sexual ou interesse por sexo. Não é muito usual, em linguagem corrente, o seu uso para caracterizar o "frio". Na poema de Sena, parece prevalecer a dimensão erótico-sensual do adjetivo, a não excluir a dimensão física de ser, o vento, também frio, e indiferente, apático. Desse jogo semântico resulta, talvez, a dimensão erótica do poema.
} 
O poeta retorna à Grécia, ou melhor, há uma volta à Creta, no poema que segue. Como possibilidade de destino último a encerrar sua peregrinação infecta junto do Minotauro, os versos aludem muito menos a uma postura escapista, em aparência, que a uma postura coerente do poeta frente ao seu compromisso com o testemunho. Lá, em Creta, observam ele e o Minotauro o mundo da vida e seus atropelos e desconsertos, como atitude pura de quem testemunha a vida de modo expectante, e aí há a possibilidade de realização da metamorfose. Jamais esquecer que o "dedo sujo", como imagem profunda e vidente, prende o sujeito à uma materialidade da qual não pode escapar, mesmo que retoricamente possa parecer o contrário.

Este retorno se dá num poema dedicado à Nikos Kazantzakis (18/02/1883 - 26/10/1957), escritor grego moderno, e ao filme "Zorba the Greek", também título de uma das mais famosas obras do escritor lembrado no título do poema, cuja temática é a de retorno ao mundo grego naquilo que a humanidade, e o próprio Jorge de Sena, tem de herança helênica. Nesse sentido, o poeta alude, em "À memória de Kazantzakis e a quantos fizeram o filme Zorba the Greek" , a duas imagens de Grécia, realizadas por outros dois poetas; em ambas a imagem grega que se pinta é muito menos a própria Grécia que uma idealização daquela terra, porque "este poesta, o que falava / de gregos, não pensava neles ou na Grécia. O outro / também não.”, sobre o que argumenta logo em seguida, e transcrevo:

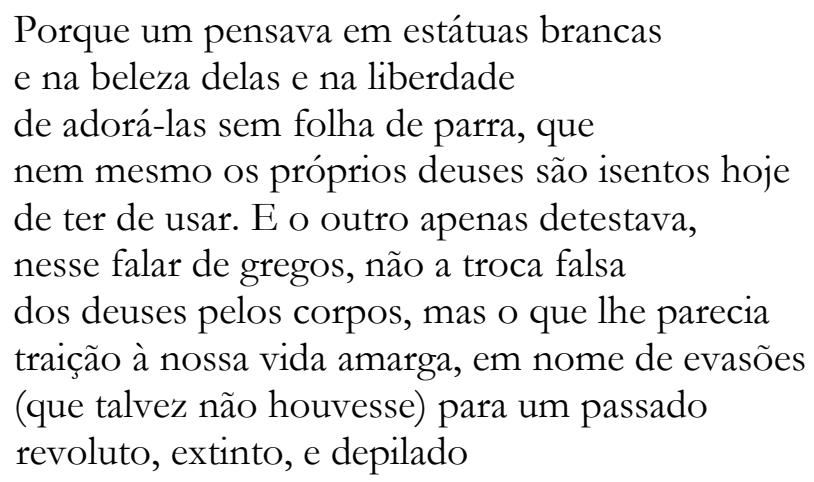

(SENA, 2013, p. 528-531)

Ou seja, de um lado, o poeta que evoca a Grécia pela via das artes, a rememorar, poeticamente, as esculturas de deuses e deusas, cuja existência ou inexistência - assim como a do Deus cristão - a Jorge de Sena pouco importava. O outro, numa via oposta, rejeita esse regresso à Grécia, porque nisso parece enxergar um ato escapista ingrato a uma realidade presente que se

${ }^{53}$ Cf. Anexo E (poema completo) 
revela mais urgente. Num caso e no outro, ele alerta: não se trata de Grécia, de fato, se não uma visão ideal daquilo que pouco importa, em detrimento do pensar aquilo que dos gregos a humanidade herdou e permanece como chaga. O poema-homenagem, aliás, não fala da Grécia, ou de gregos, se não do próprio tempo presente, fato que garante o sopro circunstancial das meditações ali realizadas.

De mais a mais, a segunda estrofe do poema-homenagem traz ao leitor a imagem de Ulisses, e aí há a inserção do tema do exílio. Falei anteriormente, à apresentação da Peregrinatio seniana, de uma tradição portuguesa para a partida, e isso não é novo, tampouco ideia original minha própria. De fato, Jorge de Sena mesmo alude a essa tradição, quando escreve em 8 de Junho de $1971^{54}$, no poema "Borras de Império", feito em quatro partes, acerca da situação dos portugueses, e a da sua própria, como consciência já lúcida de seu destino definitivo para o exílio, se bem que bem antes, pela leitura de poemas anteriores a este que logo passo, o poeta já desconfiava, de modo bastante certeiro, que não haveria de retornar à Portugal em caráter definitivo. Nesse sentido, ecoa em tom afirmativo a voz do poeta:

\section{IV}

Portugal é feito dos que partem

e dos que ficam. Mas estes

numa inveja danada por aqueles terem

sido capazes de partir, imaginam-lhes a vida

a série de triunfos sonhados por eles mesmos

nas horas de descrerem da mesquinhez em que triunfam

todos os dias. $\mathrm{E}$ raivosamente

escondem a frustração nos clamores

da injustiça por os outros lá não estarem

(como eles estão), do mesmo passo

Que se ocupam afanosamente em suprimi-los

(não vão eles ser tão tolos -

- a ponto de voltarem -

$$
\text { 8/6/1971 }
$$

(SENA, 2013, p. 634)

Ou seja, Portugal é feito de um sentimento coletivo de partida, porque, se de um lado há os que partem, e não mais voltam, do outro, há os que lá ficam na ânsia de uma partida. A distinção

\footnotetext{
54 O poema IV integra a seção IV do emblemático Exorcismos (1972). Publicado logo após a sua Peregrinatio, este livro traz poemas ainda sob forte influência da circunstancialidade do exílio. A epígrafe desta quarta parte, reputada à Tomás Ribeiro, de quem se lê, "Meu Portugal, meu berço de inocente", não poderia ser menos coerente ao conteúdo que se lê nos próprios poemas de Jorge de Sena.
} 
entre uma categoria e a outra de portugueses, se há, haveria de passar pela regulação sentimental da raiva, que toma o coração dos que decidem ou são obrigados a ficar na terra portuguesa. A hipótese dialoga bastante com a estrofe do poema-homenagem, onde aparece a questão do regresso à pátria. Ulisses foi o fundador mítico de Lisboa, cidade natal de Jorge de Sena, e "uma vida inteira / é qual regresso à pátria demorado / para que apenas de velhice ainda a aceitemos." Novamente, a questão do tempo e a de sua passagem associada ao envelhecimento, tempo que fornece alguma sabedoria, ao poeta, e entendimento de que, nas condições em que se encontra, uma vida inteira seria como que regressar à pátria. Para Sena, o regresso à pátria portuguesa - nem ditosa e nem amada, diz num de seus versos emblemáticos - custou-lhe uma vida inteira e a própria morte.

No que retira o véu por sobre as duas visões de Grécia, que pouco importam, o poema constrói uma outra ideia a ela referente, na expressão de que "eles [os gregos] / divinamente são a guerra em nós.” E, nesse sentido, o poeta retoma poeticamente à ideia manifestada em sua cartapoema, qual seja a de que a humanidade é feita do elo de cadeias sucessivas de tragédia e horror. Os "fuzilamentos", o "heroísmo", "este horror", de que disse com assombro do quadro de Goya, mas também da situação em que viveu, foi “uma coisa, entre mil, acontecida em Espanha (...)” e segue “(...) Mas isto nada é, meus filhos. / Apenas um episódio, um episódio breve, / nesta cadeia de que sois elo (ou não sereis)". Desse elo, que remonta aos gregos, é feita a humanidade.

É já, a esta altura, de se perceber que a seção americana da Peregrinatio parece aproximar-se da seção brasileira naquilo em que ambas têm de ausência dos espaços referentes a produção dos poemas. Em todo caso, os motivos da ausência aqui podem ser outros. Se se leva em consideração os títulos de cada poema da seção, e neles se encontre alguma chave de entrada dos poemas, parece que o próprio poema perde em potência. Cada título é enganoso, na medida em que, se por um lado, sinaliza fortemente para a construção de um panorama paisagístico americano, por outro, os temas ali encontrados variam, mas tocam-se na questão fundamental do tempo. Os títulos dos poemas, quando referentes aos Estados Unidos da América, evocam muito menos o espaço americano em si - ou tem a paisagem como referente imediato - que a aspectos de materialidade e de fluidez do tempo.

O poema a seguir, por exemplo, parece dialogar com a chave de leitura proposta logo acima. Nele, o poeta retorna ao tema das estações do ano, num título que evoca, simultaneamente, tempo e espaço, na relação muito especial que essas duas dimensões da experiência em ato tem entre si: Primavera (estação do ano) + Wisconsin (localização - EUA): 


\begin{abstract}
Na limpidez tranquila da manhã diáfana em que as despidas árvores imóveis são como nervos ou expectantes veias no corpo transparente do azulado ar, as águas quietas, mas não tanto que nelas se espelhe mais que a concentrada cor do ar tranquilo, nem tão menos que pareçam gelo perto as águas mais distantes, pousam na margem delicadamente como na mesma terra infusas se dispersam dos ramos e dos troncos sombras confundidas. A terra se amarela de ante-verde e, sêca, espera, entre a neve que foi e o ténue estremecer da seiva que desperta.
\end{abstract}

Madinson, 15/3/1966

(SENA, 2013, p. 531-532)

Como dito acima, o ritmo do poema repousa numa meditação dedicada e sensível acerca do tempo. Quase poderia ser dito que o poeta assume uma postura escapista, talvez quase bucólica, de contemplação da paisagem que passa por seus olhos, mas isso não seria, de todo, Jorge de Sena. As imagens são firmes e dialogam com a sua trajetória poética. A manhã é, ao mesmo tempo, límpida e diáfana; as árvores assumem as características de nervos e expectantes veias, como é expectante o seu próprio olhar. E o poema surpreende quando dá ao leitor a forma do ar: o ar tem um "corpo transparente" revestido de um tom "azulado". Mas quando, ao fim do poema, a imagem da "terra" torna-se amarelada pelo "ante-verde", à espera da neve, não naquela terra dos seus "Paraísos Artificiais", sua pátria, mas "noutros lugares", o poema confirma sua temporalidade, impondo não somente à terra que espere, mas também o sujeito, pelo porvir.

Não parece nem de longe um ato escapista. Na via oposta, o poeta mostra-se bastante imerso à paisagem que pinta poeticamente, de modo expectante e ativo, assim com os galhos das árvores que observa. Não fala de sua terra natal, não fala do Brasil, mas fala de tempo, e ao tempo o fenômeno do exílio está associado, sobretudo em seu caso muito específico, a partir de sua postura poética comprometida com o testemunho. Tudo se adensa, em sua peregrinação americana, no seu assumidamente político "Noutros lugares”. De todos os poemas desta seção, este é o que reflete de maneira mais aparente sobre as vicissitudes do desterro.

A despeito de obras modelares e profundas que a circunstância de exílio possa provocar, e provoca, esta experiência ainda deve ser encarada como aquilo que de fato é: fratura e dezenraizamento. Um das formas mais impiedosas de negação ao outro o convívio com os seus co-irmãos, com a sua terra, por fim, de negar a dimensão própria do ser, da identidade. Neste 
poema, é impossível não retomar a estrofe última de seu "poema grego", em especial os últimos versos, daquele feito em homenagem ao poeta grego, e com quem dialoga:

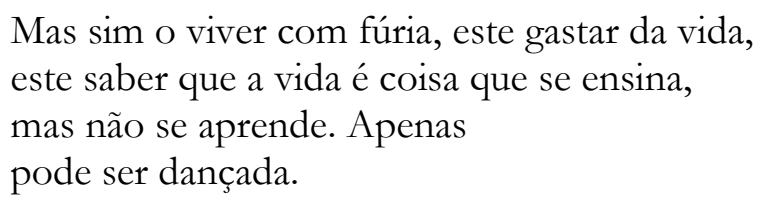

(SENA, 2013, p. 528-531)

O viver com fúria é, em quais medidas, compatível com o viver de modo atento e vigilante, de maneira expectante? Parece-me que ambas as posturas assinaladas, a do poema e a de fora dele, complementam-se dialeticamente, porque, se no testemunho seniano, os sentidos da visão e da audição, como apontou Lourenço (2010), figuram como sentidos fundamentais do objeto poético, eles mesmos não atuam de maneira passiva ou receptora, no sentido de que apreendem a experiência dada, e só. Fosse assim, a poesia seniana poderia ser reduzida a muito menos daquilo que efetivamente é. Nesse sentido, os verbos ver e ouvir, senianos que são, atuam ativamente neste mundo e, por isso, são compatíveis com este viver em fúria e este "gastar da vida" que perscruta e sabe do mundo como sabe a testemunha sempre expectante surgida nos seus "Noutros lugares" 55 .

O poema reflete sobre o tempo, também, porque como já dito, o tempo exerce fundamental relação com a circunstância de exílio. Não seria demasiado lembrar que Jorge de Sena nasce em um dos séculos de muita expressividade em torno da experiência dos deslocamentos geográficos, o século 20. As fraturas que decorrem dessa experiência são muitas e estão estrategicamente situadas ao longo desta pesquisa, por meio da análise de poemas que, em maior ou menor grau, refletem um grau de muita aproximação entre os versos postos na boca do sujeito poético e da pessoa do poeta. No poema acima, fica-se sabendo da dura condição do ser-se exilado, ou seja: aprender a viver com bem pouco, dos outros e da vida.

O tempo, categoria da experiência tão presente na poética seniana, logo ensina ao poeta que ele: "o tempo nos afina e nos apura". Impossível não recordar dos versos de sua "Glosa a Guido Cavalcanti”, quando, à maneira de reposta ou auto-explicação a uma pergunta não feita, mas imaginada, afirma que: "Porque não espero de jamais voltar / à terra em que nasci; porque não espero / ainda que volte, de encontra-la pronta / a conhecer-me como agora sei / que eu a conheço; [...]". Ora, o poeta ali e aqui reflete sobre a passagem do tempo em sua dimensão

${ }^{55}$ Cf. Anexo F (poema na íntegra) 
transformadora e modificadora de vidas e de consciências. Entre a escrita do poema de que agora me ocupo e a sua glosa vão sete anos, e nada havia mudado essencialmente em Portugal.

O que se afinou e o que se apurou no poeta e em sua terra madrasta? De Portugal, não parece ter ocorrido mudança sincera, se se pensa que a ditadura salazarista só viria a ser derrubada no ano de 1975, e o poema é de 1961, quatorze anos antes entre um e outro acontecimento. Entretanto, em Jorge de Sena, o muito que já era, em termos de formação humana e filosófica, apurou-se na constituição de uma obra pensada e vinda à lume em situação de distanciamento geográfico, quando se pensa que a sua produção do tempo de exílio fornece elementos suficientes e ricos para uma análise de sua poesia de exílio em coerência, sempre, aos princípios que elencou como os norteadores de seu testemunho poético.

O poema, aliás, ao falar do tempo e da sua passagem, por sobre o próprio ser do poeta desloca, aqui, para os próprios seres humanos, como marca material de que o tempo não se mantém imóvel. Os versos podem assustar pelo seu tom, porque o que o antecede são poemas de composição algo tranquila em torno das questões do exílio, no que tem, em sua estrutura, a composição de paisagens evocadoras do tempo. Aqui, o sujeito poético reassume o tom severo de que é constituído os demais poemas nos quais a temática do exílio é forte e explicitamente presente. Ser-se exilado, como foi o poeta por diversas vezes, é navegar por entre caminhos que justifiquem a permanente negativa - são cinco "não" na primeira estrofe - de que o poema acima é composto, como se o sujeito poético respondesse, a todo instante, a uma pergunta que somente aparece de modo implícito.

A relação do sujeito com o seu destino é acentuada de modo trágico nesta estrofe, quando ele estabelece uma importante relação entre a existência dos lugares, ou antes a sua permanência, e a inserção dos seres humanos neles. Parece que, aqui, o sujeito tem uma consciência bastante contemporânea e alinhada à perspectiva fenomenológica de entendimento da paisagem, de que os lugares só podem existir em relação ao sujeito, porque lugar é uma categoria que suscita as afetividades das pessoas que nele habitam. Lugar, na perspectiva de Tuan (2012), se não se esqueceu, pode ser associado ao lar, em oposição antitética ao sentido de espaço, no que tem de liberdade e aventura:

\section{$[\cdots]$}

É que os lugares acabam. Ou ainda antes de serem destruídos, as pessoas somem, e não mais voltam onde parecia que elas ou outras voltariam sempre 
por toda a eternidade. Mas não voltam, desviadas por razões ou por razão nenhuma.

Nesse sentido, os lugares deixam de existir mesmo antes de serem destruídos fisicamente, porque neles mesmos já não habitam mais as pessoas, que "somem, / e não mais voltam onde parecia / que elas ou outras voltariam sempre / por toda a eternidade." É uma reflexão que muito se adequa a todo ser em estado de descontinuidade, Said (2003) apontou, e sobretudo a Sena. Ele mesmo jamais retornaria ao seu Portugal natal, constituindo-se como figura de ausência na abertura democrática portuguesa, em 25 de Abril de 1975, para a qual não fora convidado, não fora chamado. Sophia de Mello Breyner Andresen, num texto em homenagem à figura do poeta, de 1976, comenta enfaticamente acerca desta ausência imperdoável:

\section{Texto homenagem de Sophia de Mello Breyner a Jorge de Sena ${ }^{56}$}

Se penso em Jorge de Sena penso nos seus poemas, mas penso igualmente na sua ausência. Pois esta ausência é como uma parte da nossa vida e do nosso país que nos roubaram. É uma forma de termos menos a pátria que temos e a vida, única, que tem.

A 25 de Abril pensámos que éramos um país que se ia reconciliar consigo próprio e que se ia reconhecer. Acreditámos na transparência possível. Acreditámos que a lei da negatividade iria ser ultrapassada. A continuada ausência de Jorge de Sena também nos diz que algo não correu inteiramente bem. (Por Sophia de Mello Breyner Andresen)

Em sua seção americana, portanto, não me parece firmar uma paisagem marcante, tal qual aquela de Portugal que acompanha o poeta em toda a sua obra poética. Se do que há de Brasil numa seção pretensamente brasileira, em sua poesia, repousa na construção de uma paisagem ausente, ou feita de ausência poética, do que as cartas que trocou com Sophia Andresen demonstram o elo afetivo entre o poeta português e a pátria brasileira, sob a marca da amargura e da infelicidade, a "pátria americana” parece também ser ausente, mas de modo diverso, na medida em que quando dá rastros de seu aparecimento, em geral está a serviço de meditações do poeta

\footnotetext{
${ }^{56}$ Este texto, endereçado a Jorge de Sena e à Mécia de Sena, data de Setembro de 1976 (Lisboa). Foi lido em sessão pública de homenagem ao poeta, na Associação dos Escritores, após o seu falecimento, ocorrido em 1978, nos Estados Unidos.

In: Correspondência, com Sophia de Mello Breyner Andresen (1959-1978) (p. 152-4)
} 
acerca de uma materialidade e a de sua inserção no tempo que, implacavelmente, passa e não retorna.

A sua Peregrinatio ad Loca Infecta, entretanto, não encerra em sua porção americana, na medida em que o poeta dedica um conjunto de oito poemas suscitados durante o seu breve regresso à Europa, à guisa de levantar dados de pesquisa sobre literatura, em projetos que estava a desenvolver na Universidade de Califórnia (Santa Bárbara). Os poemas estão coligidos sob o título curioso "Notas de um regresso à Europa" e chamam a atenção pelo seu caráter descritivo e detalhista, apreendido pelo olhar daquele que regressa, depois de tanto tempo longe, a uma Europa que lhe parece simultaneamente familiar e estranha. A epígrafe dupla: de Mallarmé e de Safo faz todo sentido ao término da leitura dos poemas:

Au seul souci de voyager... ${ }^{57}$

\section{Mallarmé - Poésies}

Ao lar, Vésper, tu fazes que regressem todos

Que a radiante Aurora aos longes conduziu:

Ovelhas ao redil, as cabras aos apriscos,

E os filhos para ao pé de sua mãe.

Safo

Dos versos epigrafais, entende-se o valor da "viagem" como primado, mesmo que ela se dê de maneira despropositada; e nos demais, a importância do regresso, como acontecimento inevitável a todo aquele que se põe ou é posto em estado de distanciamento. Em "Travessia", a exemplo, a ligação do sujeito com o mar é simbolicamente marcada pela metáfora que a transpõe ao nível do sangue - a recordar o que foi dito acerca da imagem do "sangue" no poema "Vampiro", de 1950. Com efeito, o "mar", apresentado em vocativo, é "perene sangue" a que o poeta sempre regressa, numa relação umbilical de pertencimento tão fundamental na história de Portugal, e na de tantos poetas, ao longo dos séculos:

\section{TRAVESSIA}

Após cinco dias de sonolenta travessia quase sem barcos, e sem nenhum ailha, apenas sobre um mar de ondeado azul sombrio ou de estanhada palidez monótona (ó mar - perene sangue a que regresso nesta viagem como um ventre, um ovo,

\footnotetext{
${ }^{57}$ Em tradução incipiente: "For the sole purpose of travelling..." Ou seja, "Para o único propósito da viagem...".
} 
o sumptuoso paquete de New York a Southampton), de madrugada entrámos um par de horas, no Havre.

O tempo era pouco para ver-se a cidade.

Desci porém a terra, tonto como uma criança, pousando com cautela os pés no cais.

Não por ser a França o que pisava na calçada suja:

Europa

(mais velha, como eu, quase dez anos)

$$
5 / 5 / 1969
$$

(SENA, 2013, p. 549)

O regresso à Europa provoca no ser do sujeito estranhamento e excitação, tontura. Para além da indicação simplista do "ver a cidade", o que poderia sinalizar para a visão com o olhar do turista, olhar contemplativo. Essa postura sinaliza, antes, para um retorno, ou mesmo para um mergulho profundo e de fusão entre o sujeito e este "mar" tão seu, e numa dimensão próxima, uma Europa igualmente tão perene e sua. O tom do poema permanece nos demais, dos quais destacarei alguns trechos:

\section{ENCONTRO COM VERMEER EM DELFT}

Fui deambulando pelas ruas, cruzando canais, seguindo à margem de outros, em direção à praça principal, e a esparsos vultos que da quietude emergem (como na vista da cidade, com o petit pan de mur jaune) Pergunto onde Vermeer morara. $[\ldots]$

$$
(7 / 5 / 1969)
$$

(SENA, 2013, p. 549-550)

À procura da casa em que morou o pintor holandês Johannes Vermeer (31/10/1632 15/12/1675), cuja obra mais famosa parece ser o quadro em que pinta uma moça de brinco (Girl With a Pearl Earring ${ }^{58}$ ), o poeta deambula pelas ruas, ao que parece ainda embriagado - os vultos esparsos aqui importam - pela tontura e pela excitação de estar novamente na Europa, sua terra,

\footnotetext{
58 As demais pinturas de Johannes Vermeer podem ser encontradas neste site: «http://www.essentialvermeer.com/vermeer_painting_part_one.html\#.WVMYqsaQzIU»
} 
como afirma dolorosamente, no poema seguinte. O poeta faz as pazes com a Europa, mas não com Portugal, aparentemente. Estar de volta à sua terra o relembra da importância da resistência a toda forma de abuso imposto por um governo ou outros seres humanos.

\section{CHARTRES OU AS PAZES COM A EUROPA}

Em Chartres, ó Peguy, eu fiz as pazes

com a Europa. Não que eu estivesse zangado, mas estava esquecido.

$[\ldots]$

Depois, Nossa Senhora, Chartres, Idade Média, e a paz desta saudade n'alma

e a certeza de que este mundo tem de resistir

-- e há-de resistir - à grosseria,

às bestas e ao vulgar, às multidões, a tudo:

$[\ldots]$

a nossa humanidade é pedra sem retorno

à natureza informe. Tal como a Deusa-Mãe

na cripta contida se transforma

nesta de vidros ascensão fremente

de cores que a luz acende mas não passa.

Europa, minha terra, aqui te encontro

e à nossa humanidade assim translúcida

e tão de pedra nos pilares sombrios.

Chartres, 10/11/1968

(SENA, 2013, p. 550-1)

A afirmação é categórica, do que não se tem dúvidas, a dimensão biográfica do poema é gritante: o sentimento de pertença à esta Europa a que regressa temporariamente é transmutado em poesia, de que fala ao seu leitor da humanidade como coisa que sempre lhe foi fundamental e que aparece em diversos poemas ao longo de sua obra, e nos de exílio, sobretudo. O tema da humanidade, cabe notar, é o que parece ligar este poema ao que lhe sucede, quando surge à consciência poética uma lufada de fé na "grandeza humana", não em Deus ou deuses, senão na própria humanidade ${ }^{59}$, tópico ao qual Jorge de Sena também perquiriu em seus poemas.

\section{FLORENÇA VISTA DE SAN MINIATO AL MONTE}

\footnotetext{
${ }^{59}$ Cf. Prefácio à segunda edição de Poesia-I. Ênfase no último parágrafo, encontrado entre as páginas 743 e 745 . In: Sena, 2013, p. 732-745. Escrito em Santa Barbara, Julho de 1977.
} 
$[\ldots]$

$\mathrm{Na}$ esplanada sobre o vale, sento-me

ao silêncio do entardecer, vendo

Florença, com as suas cúpulas e torres, que escurece

austera e refinada: o Duomo, o Bargello,

Santa Croce, os Uffizi, o Palazzo Vecchio,

a ponte antiga, o Campanile, tudo - e os montes

e os ciprestes, e o céu pálido, a lua:

um momento incrível de fé na grandeza humana,

que não existe já mas paira ali suspenso,

ecoa pelas praças e nos pátios,

um misto de rigor e de volúpia, dignidade

das coisas e das formas, que o cardel,

aqui do alto, e na margem oposta,

velou dormindo, e vela, virginal.

$$
10 / 5 / 1969
$$

(SENA, 2013, p. 551-2)

Este sentimento de fé é produto, no poema, da sensação algo íntima do poeta com o espaço circundante, repousada numa suspensão temporal, e permanece de uma grandeza e de uma beleza poética o instante sublime em que o poeta reafirma a sua fé numa humanidade, muito embora a postura que adote seja sempre a de uma desconfiança quase metódica acerca de tudo aquilo que está porvir no curso da História, para o melhor e para o pior, porque a humanidade, como elo de cadeias e sucessivas atrocidades, de tudo é capaz, inclusive de ser bem pior que a geração e os anos em que viveu com profunda dignidade e sentimento ético.

\section{RELATÓRIO}

Sessenta cidades (com os museus, as ruas, castelos,

em doze países em quatro meses (very american)

$$
\text { [catedrais, etc.) }
$$

além de manuscritos em várias bibliotecas, conferências

em Londres, Paris, Bruxelas, Nimega, Utrecht, e os príncipes de Portugal (medievais e Renascença pela

[Europa adiante),

e alguns cinemas, exposições, teatros, muita vadiagem

altamente imoral (mais os desejos que as ocasiões),

e honestos encontros com amigos velhos e com amigos novos,

um incidente de fronteira, muitas entrevistas, leituras públicas de poemas, um calor de glórias

(oh efémera, já Salomão sabia), uma

operação à vesícula. E numa tarde chuvosa

o navio largando. Os amigos sob os guarda-chuvas.

$\mathrm{E}$ a falta de palavras com os que estavam a bordo

a despedir-se. E na bruma tempestuosa 
subitamente

nada.

$$
7 / 5 / 1969
$$

(SENA, 2013, p. 555)

A dimensão biográfica de sua poesia feita de testemunho acentua-se neste poema que encerra o seu ciclo de regresso à Europa. O poema "Relatório" deve ser lido como relatório, ou seja, relato e descrição das peregrinações efetivadas no território europeu no tempo em ele lá regressou na qualidade de pesquisador universitário. Foram doze países visitados e, de maneira mais íntima, vistos de dentro, em quatro meses. Diversas as atividades desempenhadas, das obrigações universitárias aos encontro afetivos com amigos de longa data. E, então, vem um verso do poema que é o próprio Sena a relatar a operação emergencial à vesícula, ao qual se submeteu em Portugal - "uma / operação à vesícula."

Entretanto, o poema excede os limites do simples relato de viagens das terras percorridas no momento final de sua construção quando, quase à maneira de Pessoa, no seu "Nevoeiro" que fecha Mensagem (1934), o poeta pinta a cena amarga com que encerra sua viagem: chove e paira no ar uma bruma, o navio parte, não há palavras, cá e lá, no navio e no caís, e nesta mesma bruma: nada. Nesse sentido, o poema ganha em sua riqueza de sentidos e de leitura, na medida em que passa de um tom documental e de registro técnico de viagens à impressão humana com que colore amargamente, para não dizer raivosamente, a sua relação com a sua pátria Portugal, e, numa gradação contrária, o Brasil e os Estados Unidos.

Das cartas que o poeta trocou com Sophia Andresen, não há muitos rastros de sua relação afetiva com pátria de T.S. Eliot e a de Edgar Allan Poe. Se do Brasil, nelas há larga notícia, sobre os Estados Unidos o poeta disse pouco, e, ao que parece, nunca em tom muito afetivo. Há, entretanto, um livro de poemas seu, publicado sob o título bastante irônico, talvez, "America, America, I love You", uma reunião de sua produção compreendida entre os anos de 1969 e 1970. A obra foi publicada postumamente, pelas mãos de Jorge Fazenda Lourenço, no tomo Poesia 2 $(2015)^{60}$, cujo volume reúne toda a produção poética de Jorge de Sena que não viera à lume durante a sua vida.

Sobre esta coletânea de poemas, 28 ao total, a crítica Dora Gago aponta para o tom satírico deles, em ensaio encontrado no portal Ler Jorge de Sena, projeto abrigado pela Cátedra de Jorge

\footnotetext{
${ }^{60}$ Poesia 1, o outro volume, reúne toda a obra poética de Jorge de Sena publicada em vida: portanto, de Perseguição (1942) à Sobre esta praia... Oito meditações à beira do Pacifico (1977).
} 
de Sena, da Universidade Federal do Rio de Janeiro, aos cuidados da estudiosa da obra do poeta Gilda Santos. À Dora Gago, entretanto:

\begin{abstract}
Assim, os referidos poemas de "América, América, I love you", apresentam pequenas histórias que criticam de forma irónica e satírica o quotidiano, por vezes. absurdo dos Estados Unidos, focando temas como o sexo, a doença ou os costumes.

Neste contexto, Jorge de Sena, através de uma óptica etnocêntrica, recorrendo a observações, nem sempre provavelmente observadas, veicula uma imagem estereotipada deste seu segundo país de acolhimento, sobre o qual deixa transparecer alguns juízos de valor. Deste modo, critica a hipocrisia subjacente ao capitalismo, ao suposto espírito e tolerância democráticos revelando uma imagem cáustica e estereotipada do país. (GAGO, s/a, s/d) ${ }^{61}$
\end{abstract}

Tais traços não são encontrados em sua Peregrinatio ad Loca Infecta, pelo que são convocados apenas para demonstrar o contraste e a permanente tensão encontrada na relação de Jorge de Sena com as terras a que chegou, em seu destino de ser-se, para toda a vida, um poeta em exílio constante. Da seção americana, parece estar clara as dimensões da paisagem e a sua relação íntima com o poeta.

Poderia parecer que a seção americana da peregrinação infecta fosse apresentada, estruturalmente, como a última, como episódio que encerra o arco do destino do poeta. Entretanto, não ocorre assim, porque aquela seção é seguida dos oito poemas dedicados ao regresso do poeta ao seu velho continente. Parece, portanto, que os Estados Unidos da América figuram mesmo, em termos de importância para a peregrinação seniana, como espaço que possibilita a Jorge de Sena o vislumbre em caráter último de sua Europa, "mais velha, como eu, quase dez anos", como disse em seu poema. A obra finaliza com dois regressos importantes: à sua terra, pelos oito poemas, e à sua herança grega, através de "Ganimedes" (1969), como paisagem que marca bastante a sua própria poesia.

\footnotetext{
${ }^{61} \mathrm{O}$ ensaio de Dora Gago acerca das imagens dos Estados Unidos e da Inglaterra na obra de Jorge de Sena pode ser integralmente encontrado e lido neste link: «http://www.lerjorgedesena.letras.ufrj.br/ressonancias/pesquisa/estudos/6-uma-cartografia-do-olhar-imagens-deinglaterra-e-dos-estados-unidos-na-obra-de-jorge-de-sena/»
} 


\section{CONCLUIR É PRECISO...}

Jorge de Sena foi acusado por seus primeiros críticos de ser um poeta intelectualista. De fato, o poeta construiu uma obra hermética, mas não impenetrável, na perspectiva de leitura sua primeira crítica. À guisa de desviarem dos problemas fundamentais impostos pela poética seniana, identificá-la pelo seu caráter "intelectualista” resultou na negação de leitura atenta e cuidada de uma poesia tão profusa como é a do testemunho. Uma negação que recusa ao ser do poeta o básico: ser. Ora, o que a poesia de Sena tem de intelectualista reside no fato preciso de que é uma poesia que não se presta a leituras fáceis, de referentes imediatamente encontrados, e, sobretudo, de fácil enquadramento estético-poético nas opções disponíveis à época em que começa sua escrita poética.

Se por um lado a poesia seniana apresenta poemas que exigem um repertório poético e cultural de várias fontes, por vezes intuído pelos rastros de leitura deixados pelo poeta; outras vezes, há outros poemas que podem ser facilmente lidos e ali descobertos os temas que the dão sopro de vida. Ainda assim, o rigor estético não lhe abandonou jamais. A poesia seniana foi feita de suas relações dialogantes e dialéticas com as vertentes de produção poética - o sopro de Presença, Neorrealismo, Surrealismo - que transitam por sua obra. O intelectualismo reside no entendimento de que, assim como na sua vida pessoal, a vida poética é marcada por uma atitude dialética que deve ser sempre levada em consideração.

Nesse sentido, os poemas que aqui foram analisados tiveram em sua maior parte a enorme vibração circunstancial emanada da experiência dos múltiplos exílios pelos quais passou o poeta, e acostumou-se como destino permanente. Estes poemas deram a ver uma presença constante e necessária, à guisa de evocação pela ausência material, de sua pátria natal, o Portugal cada vez mais distante, em termos geográficos, e, opostamente, cada vez mais presente em sua consciência poética. Ainda que, e por isso mesmo senianamente, a visão marcante que se imprimiu das figurações de sua terra esteja eivada de uma postura, intelectual e poética, de caráter complexo, de onde amor e ódio, além do pólo esperança-desesperança, apresentam-se como quadro sentimental que coloriu a sua poesia feita de e em exílio, num testemunho sempre atento do mundo.

Não há como fiar por completo nos versos do poeta, quando em seu poema "Em Creta, com o Minotauro" falou de nacionalidades como camisas que se despem. De fato, é uma visão interessante, porque relaciona o tópico da nacionalidade à questão do exílio. Há, em contrapartida, a sua poesia disso dá conta, uma vontade - terrivelmente circunstanciada, como todo exílio o é para a peregrinação, naquilo que ela tem de viagem ao desconhecido, que, em Sena, não o permitiu deixar de vislumbrar o seu Portugal natal. Afinal, de que modo, então, entender o aparecimento 
constante de sua pátria - que "nem é ditosa, porque não o merece. / Nem minha amada, porque é só madrasta." - em versos e seções que às outras pátrias suas, Brasil e Estados Unidos, deveriam ser dedicadas?

Não só como imagem que carrega um forte simbolismo, porque penso que é exatamente ela que garante ao poema o seu caráter de "poema-rio", tal qual Francisco Cota Fagundes (2001) o identificou, o "dedo sujo" seniano apontou para as dimensões de sua relação com o Surrealismo português, de caráter abjeccionista. E não só, porque o "dedo sujo" emergiu como postura poética que interfere na visão e apreensão da paisagem do poeta e, por conseguinte, no objeto estético transmutado no poema. Muitas seriam as chaves de leitura deste importante sintagma, aqui desenvolvi algumas delas, na esperança de ter fôlego para uma pesquisa futura que investigue seus efeitos de sentido na poética seniana, em sua obra poética como um todo.

Este sintagma foi, aliás, o que principiou o ensaio segundo, no qual foram analisadas as relações do poeta com o Brasil. De certo, o ensaio não deu respostas definitivas, e mesmo a poesia de Jorge de Sena nas as dá. Importante não esquecer de sua "pequenina luz", que não ilumina e tão somente "bruxuleia" no espaço. A poesia seniana obrigou-me a seguir por uma via de leitura fecundada pela incerteza, afinal, a postura que se mostra, nos poemas de sua seção brasileira, não davam conta de um sentimento de "amor" pelo Brasil, muito menos de "ódio", e nisso é que a seção, e a sua Peregrinatio como um todo, ganham força de sentidos e de possibilidades de leitura. $\mathrm{Na}$ dificuldade imposta pela poesia, optei pelo caminho da ausência em sua relação com os sentimentos de saudade, melancolia e nostalgia, como Eduardo Lourenço (1999) os entende.

Não foi o motivo da saudade a uma pátria distante de que fala a poesia seniana. Fosse isso, o caminho seguido para a sua leitura teria sido outro e não desembocaria na constituição, em relação ao Brasil e aos Estados Unidos (mas de modo diverso), em paisagens feitas de ausência. O sentimento de Jorge de Sena pela pátria foi construído pelo viés da raiva, da amargura e de uma esperança desesperançada. Entretanto, é preciso cuidado: a poesia feita de raiva não significou ausência de Portugal e o seu esquecimento. Talvez, seja justamente porque feita de raiva e de amargura, advindas de sua ética fundamental, que Portugal é nela tão presente, como se, pela poesia, fosse possível modificar o Portugal que, em muitos modos, era diverso daquele que o poeta e tantos outros, também exilados ou não, esperavam ser.

Este ensaio alongou-se mais que o primeiro e que o terceiro por uma razão: a análise não ficou circunscrita somente aos poemas, mas expandiu-se para o espaço confessional presente na correspondência trocada entre o poeta e a sua muito amiga, e poeta, Sophia de Mello Breyner Andresen. Neste espaço, diverso do espaço de sua escrita poética, feita em modo de testemunho, 
rastros confessionais foram convocados para o estabelecimento de um contraponto entre a postura testemunhal e a da confissão. Não é demasiado lembrar que a poética seniana carrega em si algo do fingimento pessoano. Entretanto, achei importante pontuar a relação entre "presença" e “ausência” no que se refere à (não)figuração de sua sentimentalidade brasileira em sua poesia.

O terceiro ensaio constituiu-se na tentativa de verificar se a mesma ausência em relação à formação de uma paisagem brasileira se configurava na construção poética de uma paisagem americana. Pois bem, como ficou dito no ensaio, aquilo que seria, através de títulos espaciais, indício de uma visão da paisagem naquilo que ela tem de entrelaçamento entre o olhar e o espaço, transforma-se em meditação profunda acerca da materialidade do tempo. O poeta novamente brinca com estas duas categorias experiencias - tempo e espaço (paisagem) - e daí extrai a matéria formadora de seus poemas americanos.

Como disse, é preciso dar um fim. Por isso, a análise não percorreu detidamente, a não ser por breve remissão, os poemas de seu postumamente publicado America, America, I love you, cujo título pareia em termos de ironia com a sua própria Peregrinatio ad Loca Infecta. Das cartas com Sophia Andresen, ficou o alerta de que não se fala muito, ali, de sentimentos em relação aos Estados Unidos. Entretanto, sobre as Américas de modo geral (a do Norte e a do Sul), escreveu, a 4 de Dezembro de 1971, de Santa Barbara (Califórnia), para sua amiga o seguinte:

E em Los Angeles estaríamos eu e a Mécia à vossa espera para vos trazer aqui por estas costas de escarpas e praias do Pacífico, aonde no meu luxuoso solar há espaço para abrigar um regimento, quanto mais o casal da cavalaria andante da pátria portuguesa! Não insisto para os próximos vinte e cinco anos, apenas porque ainda tenho esperança que não ficarei tanto tempo nas Américas em que já passei doze anos da minha vida (quase umas bodas de cobre ou latão, se as há, de dois matrimónios alegóricos e ambos desagradáveis, a seis anos cada um. Mas sem bodas de qualquer espécie mais que as devidas atividades quotidianas, conto que, na próxima vez, tu e o Francisco, ou ele voando entre continentes, se lembrem de que estas coisas são possíveis, e significam uma espécie de manjar celeste na pasmaceira solitária em que se vive aqui. (Correspondência, Sophia de Mello Breyner Andresen, 2006, pp. 115-116)

Sem mencionar os seus textos de teor político, sobre o que abro um parêntese explicativo: em Jorge de Sena, não há uma separação distinta entre o que é de ordem literária (poético ou ficcional) e o que é de ordem política. Tudo está e conflui em todas as dimensões de sua escrita, ou seja: o poema é político, sem ser panfletário e sem abandonar o rigor estético que lhe estrutura, a ficção é política sem perder suas características fundamentais; a sua escrita ensaística carrega, também, teor político; e, por fim, a sua escrita política. Por político, digo especificamente de uma postura pessoal sua de consciência de ser e estar no mundo de uma maneira ética, no compromisso que firma com o mundo e com o outro. 
A pesquisa acadêmica acerca da obra de Jorge de Sena, a despeito das dificuldades que encerra, tem crescido. A sua Poesia, com a mesma capital com que o próprio poeta grafou nos Cadernos de Poesia, o lema "A Poesia é só uma", tem sido objeto de interesse e tem rendido muitos estudos. A pesquisa feita nesta dissertação seguiu esta linha de interesse, ainda que pareça haver uma resistência à poesia de maneira geral, e à obra do poeta, dentro e fora dos espaços especializados.

Mesmo na dimensão igualmente importante de seus contributos enquanto estudioso atento da Literatura, não só da Portuguesa. Seus estudos sobre a épica camoniana são importantes até hoje, e ainda assim, ignoram-no, em diversos espaços desta pátria brasileira. Isso causa espanto, porque a dimensão da obra de Jorge de Sena revela-se, cada vez mais, como algo urgente a dar a conhecer. Hoje, talvez, não seja mais do que adequado e urgente que se penetre, leia e sinta junto do poeta o seu precioso testemunho poético, porque em muito tem a contribuir sobre a ética e sobre um estar no mundo com uma responsabilidade profunda com o outro e com tudo aquilo que nos medeia.

Parece, na contemporaneidade, que a situação em relação à sua leitura modificou-se um pouco, mas ainda permanece com um ar daquilo que ele identificou como um interesse circunstancial do Brasil por Portugal. Ou de brasileiros por autores e poetas portugueses. À guisa de confissão, na correspondência sua amiga Sophia Andresen, lê-se:

Mas, então, ao tempo em que as escrevia [Metamorfoses] foram claramente o resultado. Mas, então, ao tempo em que as escrevia, não chegara ainda totalmente à experiência de vácuo que nem o quotidiano nem a família me desdizem; e à amargura e insuportável conclusão de que escrevo sem saber porquê, para o deserto linguístico. É a minha experiência real: onde a língua não é nossa, como aqui, ninguém se interessa por nós, e mesmo quem estudo português não tem consciência de quem eu seja, nem se interessa por isso: pois se a crítica e os historiadores só lhe falam de Namoras e Ca.! O Brasil só se interessa eventualmente por nós, e dificilmente por poetas tão pouco folclóricos e tão severamente abstractos como eu ou a Sophia (tudo o que possa parecer o contrário é fingimento) e nem um poeta como a Cecília eles em verdade admiram, porque não é nunca convencionalmente "brasileira". (Correspondência, Sophia de Mello Breyner Andresen, 2006, p. 98)

E a seguir, a comentar sobre a publicação de livro-coletânea de poetas brasileiros, do qual fora retirado sob a alegação de que se tratava de uma reunião de "poesia brasileira", respondeu a Walmir Ayala, e comenta dessa resposta à Sophia Andresen:

É que ele [Walmir Ayala] tirava a máscara brasílico-carioca, Sophia, num bilhete que me escreveu, e em que dizia que o livro era de poetas brasileiros respondendo, com um "apêndice" de poetas portugueses... e eu disse-lhe que, para mim, a poesia era substantivo antes de ser nacionalmente qualquer coisa, e que, em todo o caso, sendo eu um poeta português, mas cidadão brasileiro 
naturalizado (que sou - e provavelmente dentro de dois anos e meio serei norteamericano, porque mudarei de nacionalidade quantas vezes possa, para que conste...) ele tinha de pôr-me no intervalo... (Correspondência, Sophia de Mello Breyner Andresen, 2006, p. 98-99)

Eu volto nesta conclusão, portanto, à Sophia Andresen, na ausência de que ela fala em relação à figura de Jorge de Sena na redemocratização portuguesa, a 25 de Abril de 1975, mas não com o texto em homenagem à figura do poeta, comentado no ensaio terceiro desta dissertação. À morte do poeta, ocorrida em 4 de Junho de 1978, tão prematura, a poeta e amiga escreveu-lhe um poema que, lido, dói, assim como dói o poema de Sena feito quando da morte de seu também amigo Adolfo Casais Monteiro. O poema recebeu o título “À memória de Adolfo Casais Monteiro" ${ }^{\circ 2}$, homenagem póstuma ao nome que o dá título.

Ora, não é dilacerante a pergunta com que inicia Jorge de Sena o seu poema: "Como se morre, Adolfo?” seguida da constatação “[...] Tu morreste”, no que segue descrevendo a cena da recepção da notícia de falecimento de Casais Monteiro nos versos seguintes. O poeta pergunta ao próprio morto, seu amigo, como se não pudesse acreditar no fato de que a morte abatera alguém tão íntimo seu. "Como se morre, Adolfo? Trinta e três / anos - uma idade perfeita -", pergunta novamente o poeta, como que reafirmando a sua incredulidade. O poema é de uma sentimentalidade trágica imensa, quase um réquiem, exceto pela dimensão religiosa-metafísica que lhe falta. Uma elegia de tom emocionante. Jorge de Sena, ao falar de Adolfo Casais Monteiro, de maneira propositada ou não, acabou falando de si próprio:

\section{$[\ldots]$}

E todavia como estiveste no mundo, como duramente bebeste toda a dor do mundo, ou a fumaste em nuvens de cigarros que matavam os teus pulmões possessos de asfixia.

Foste o estrangeiro e o exilado perfeito e por todos nós que recusámos de um salto por outras terras esta terra há séculos de outrem, morreste em dignidade, sem queixas nem saudades a queixa e a saudade mais pesadas pesadas para o fundo, sem palavras que as não há entendíveis aonde não se entende a perfeição tranquila em desespero agudo a que te deste num morrer sem voz.

$$
[\ldots]
$$

(SENA, 2013, p. 669-672) 
Este beber "toda a dor do mundo" bem o soube Jorge de Sena, porque o seu gesto poético fora sempre a isso comprometido, não à toa, o que resta como garantia de sua estadia com o Minotauro é exatamente o "dedo sujo". E no que Casais Monteiro bebeu as dores do mundo, numa postura que parece ser de amarga atenção a tudo aquilo que o rodeava, Jorge de Sena, numa postura muito idêntica, investiga as origens da vida e, nisso, resulta a sujidão com que percebe o mundo, análoga ao carácter infecto que tanto se faz presente em sua peregrinação aos locais infectos

E do que confessa poeticamente em seu poema Jorge de Sena, porque há em sua "À memória à Adolfo Casais Monteiro" muito mais de confissão que de testemunho, e nisso não há mal. Porque o que há de testemunho é potencializado pela confissão arrebatadora do poeta que sofre a perda de um amigo, de um correspondente, de um português grande, em todos os sentidos português e grande, para Jorge de Sena. Disso, parece estar ciente Sophia de Mello Breyner Andresen, quando escreve em tom elegíaco à morte de Jorge de Sena, igualmente dolorosa, igualmente arrebatadora:

\section{CARTA(S) A JORGE DE SENA}

\section{I}

Não és navegador mas emigrante

Legítimo português de novecentos

Levaste contigo os teus e levaste

Sonhos fúrias trabalhos e saudade;

Moraste dia por dia a tua ausência

No mais profundo fundo das profundas

Cavernas atlas onde o estar se esconde

\section{II}

E agora chega a notícia que morreste

E algo se desloca em nossa vida

\section{III}

Há muito estavas longe

Mas vinham cartas poemas e notícias

E pensávamos que sempre voltarias

Enquanto amigos teus aqui te esperassem -

$\mathrm{E}$ assim às vezes cegavas da terra estrangeira

Não como filho pródigo mas como irmão prudente

E ríamos e falávamos em redor da mesa

E tiniam talheres loiças e vidros

Como se tudo na chegada se alegrasse

Trazias contigo um certo ar de capitão de tempestades 
Grandioso vencedor e tão amargo vencido -

E havia avidez azáfama e pressa

No desejo de suprir anos de distância em horas de conversa

E havia uma veemente emoção em tua grave amizade

E em redor da mesa celebrávamos a festa

Do instante que brilhava entre frutos e rostos

\section{IV}

E agora chega a notícia que morreste

A morte vem como nenhuma carta

$(1978)^{63}$

Num exercício inútil, pergunto-me, à guisa de concluir estas linhas finais, o que diria do mundo de hoje Jorge de Sena. Digo ser um exercício inútil, porque as respostas poderiam ser várias, mas certamente todas elas fiadas numa certeza, pessoal, de que o poeta permaneceria fiel aos princípios que sempre nortearam a sua poesia e, sobretudo, a sua vida, que não pode ser lida sem a dimensão poética, e vice-versa. Jorge de Sena faleceu a 4 de Junho de 1978, nos Estados Unidos, em Santa Bárbara (Califórnia), vítima de câncer. Morreu longe de sua terra natal, para onde somente retornaria a 11 de Setembro de 2009, como aquele que cumpre, mesmo em morte, aquilo que disse poeticamente em seu poema "Raízes"

Raízes outras há: os mortos que nos dormem na terra em que nascemos, na terra onde morreram, e nos vivem na vida que não tendes nesta Europa finis pilritos fêmeas de outro mundos machos.

(SENA, 2013, p. 668-9)

Leu-se, na cerimônia de trasladação de seus restos mortais, a carta-poema "Carta aos meus filhos sobre os fuzilamentos de Goya" ${ }^{65}$ pela voz da atriz de Eunice Muñoz ${ }^{66}$. Creio que não poderia ter sido escolhido poema mais significativo, na medida em que, pela carta, sabe-se muito bem da pessoa ética e digna que foi Jorge de Sena, do poeta multifacetado, comprometido e fundamental

\footnotetext{
${ }^{63}$ Este poema consta, na obra de Sophia de Mello Breyner Andresen, em sua Ilhas (1979). Sua transcrição vem, entretanto, do volume de correspondências trocadas entre a poeta e Jorge de Sena, entre as páginas 144 e 145.

${ }^{64}$ Datado de 25 de Agosto de 1972 (Porto), o poema "Raízes" segue completo no Anexo H.

${ }^{65}$ Cf. Anexo B

${ }^{66}$ Esta leitura bastante dramática e significativa de Eunice Muñoz, na cerimônia de trasladação dos restos mortais de Jorge de Sena de Santa Barbara (Califórnia) para o Talhão dos Artistas do Cemitério dos Prazeres, em Lisboa, sua pátria natal, pode aqui ser ouvida e vista: «https://www.youtube.com/watch?v=5AGtWEcEQos\&t=5s»
} 
para o seu século, o 20, mas também para o nosso, o 21. Como os filhos de Sena, para quem a carta é pretensamente destinada - pelo título - e se expande a toda a humanidade, a esta linha final, não posso concluir livre daquele sentimento que sentiu Sophia Andresen e que transpôs em seu poema: "E agora chega a notícia que morreste / A morte vem como nenhuma carta.” Procurei investigar Jorge de Sena de maneira adentrada, rendendo-me, com alguma distância necessária ao exercício de crítica aqui empreendido, ao canto sedutor de sua poesia. Se fiz bem ou mal, o julgamento cabe a você, leitor. E findo aqui. 


\section{REFERÊNCIAS}

\section{OBRAS DE JORGE DE SENA}

SENA, Jorge de. Poesia-I. 2a Ed. Lisboa: Círculo de Poesia - Moraes Editores, 1977.

Poesia-II. Lisboa: Círculo de Poesia - Moraes Editores, 1978.

Poesia-III. Lisboa: Círculo de Poesia - Moraes Editores, 1978.

Da Poesia Portuguesa. $1^{\text {a }}$ ed. Lisboa: Edições Ática, 1958.

Estudos de Literatura Portuguesa - I. Lisboa: Edições 70, 2001.

. Estudos de Literatura Portuguesa - II. Lisboa: Edições 70, 1986.

. Estudos de Literatura Portuguesa - III. Lisboa: Edições 70, 1988.

Poesia 1. Ed. de Jorge Fazenda Lourenço. Guimarães Editores (Edição Babel), 2013.

Poesia 2. Ed. de Jorge Fazenda Lourenço. Guimarães Editores (Edição Babel), 2015.

. et al. A POESIA É SÓ UMA (1940-1951). In: Cadernos de Poesia, fascículo 6, série II.

Lisboa, 1951. (Ed. fac-similar de Luís Adriano Carlos e Joana Matos Fria).

. et al. A POESIA É SÓ UMA (1940-1951-1952). In: Cadernos de Poesia, fascículo 13, série III. (Ed. fac-similar de Luís Adriano Carlos e Joana Matos Fria).

Correspondência, com Sophia de Mello Breyner Andresen (1959-1978). Lisboa: Guerra e Paz, Editores SA, 2006.

\section{OBRAS E ESTUDOS SOBRE JORGE DE SENA}

ALVES, Ida Ferreira. Jorge de Sena e a ética da poesia: um testemunho para os poetas de 70. In: Jorge de Sena: ressonâncias e cinquenta poemas (Introd. e Org. Gilda Santos). Rio de Janeiro: 7Letras, 2006.

. et al (Orgs.). Estudos de Paisagem: literatura, viagens e turismo cultural. Brasil, França e Portugal. Rio de Janeiro: Oficina Raquel, 2014.

AVELAR, Mário. Sena - a ekphrasis e os diálogos teóricos. In: Jorge de Sena Vinte Anos Depois: O Colóquio de Lisboa, Outubro de 1988. Edições Cosmos, Câmara Municipal de Lisboa: Lisboa, 2001. 
BELCHIOR, Maria de Lourdes. O mar na poesia de Jorge de Sena. In: SHARRER, Harvey L. e WILLIAMS, Frederick G. Studies on Jorge de Sena By His Colleagues and Friends. Santa Barbara, CA: Jorge de Sena Center for Portuguese Studies/ Bandanna Books, 1981.

BERARDINELLI, Cleonice. Revendo e relendo Jorge de Sena. In: SANTOS, Gilda (org.). Jorge de Sena: Ressonâncias e Cinqüenta Poemas. Rio de Janeiro: 7Letras, 2006.

Jorge de Sena, meu amigo. In: Revista Metamorfoses. Volume 10.2, Alfragride: Editorial Caminho e Cátedra Jorge de Sena, 2010.

BUENO, Danilo Rodrigues. A função poético-crítica em Jorge de Sena: problemáticas do poeta moderno. 139 f. Dissertação (Mestrado em Literatura Portuguesa) - Faculdade de Filosofia, Letras e Ciências Humanas - Universidade de São Paulo, 2009.

CARLOS, Luís Adriano. Poesia e referência em Jorge de Sena. In: Jorge de Sena Vinte Anos Depois: O Colóquio de Lisboa, Outubro de 1988. Edições Cosmos, Câmara Municipal de Lisboa: Lisboa, 2001.

. Epístola aos realistas que se ignoram - Jorge de Sena e a Estética. In: SANTOS, Gilda

(org.). Jorge de Sena: Ressonâncias e Cinqüenta Poemas. Rio de Janeiro: 7Letras, 2006.

e FRIAS, Joana Matos (Editores). Cadernos de poesia (reprodução fac-similada). Porto: Campo das Letras, 2004.

CATTANEO, Carlo Vitorino. Testemunho e linguagem. In: Estudos sobre Jorge de Sena. Compilação, org. e introdução de Eugénio Lisboa. $1^{a}$ ed. Lisboa: Imprensa Nacional-Casa da Moeda, 1984.

CERDEIRA, Teresa Cristina. Nota Editorial. In: Revista Metamorfoses. Volume 10.2, Alfragride: Editorial Caminho e Cátedra Jorge de Sena, 2010.

CIRUGIÃO, António. À margem da 'poética' de Jorge de Sena. In: SHARRER, Harvey L. e WILLIAMS, Frederick G. Studies on Jorge de Sena By His Colleagues and Friends. Santa Barbara, CA: Jorge de Sena Center for Portuguese Studies/ Bandanna Books, 1981.

COELHO, Joaquim-Francisco. Jorge de Sena: 20 anos depois. In: Jorge de Sena Vinte Anos Depois: O Colóquio de Lisboa, Outubro de 1988. Edições Cosmos, Câmara Municipal de Lisboa: Lisboa, 2001.

CONRADO, Fernanda. Ehphrasis e outros processos de trânsito intersemiótico em Jorge de Sena: «O Dançarino de Brunei». In: Jorge de Sena Vinte Anos Depois: O Colóquio de Lisboa, Outubro de 1988. Edições Cosmos, Câmara Municipal de Lisboa: Lisboa, 2001.

CORTEZ, António Carlos. Jorge de Sena: «Morrerei por exílio sempre, mas fiel ao mundo» (Uma ideia de poesia como descrição e independência em Peregrinatio ad Loca Infecta). Ler Jorge de Sena, s/d. Disponível em:

$<$ http://www.lerjorgedesena.letras.ufrj.br/ressonancias/pesquisa/estudos/43-jorge-de-senamorrerei-por-exilio-sempre-mas-fiel-ao-mundo-uma-ideia-de-poesia-como-descricao-eindependencia-em-peregrinatio-ad-loca-infecta/> Acesso em: 25 de abril de 2016.

CRESPO, Ángel. Notas para un lectura alquímica de las Metamorfoses de Jorge de Sena. In: SHARRER, Harvey L. e WILLIAMS, Frederick G. Studies on Jorge de Sena By His Colleagues and Friends. Santa Barbara, CA: Jorge de Sena Center for Portuguese Studies/ Bandanna Books, 1981. 
Fidelidade e independência de Jorge de Sena. In: Estudos sobre Jorge de Sena. Compilação, org. e introdução de Eugénio Lisboa. 1a $^{a}$ ed. Lisboa: Imprensa Nacional-Casa da Moeda, 1984.

CUNHA, Kássia Fernandes da. Paisagens na Poética de Jorge de Sena: peregrinação, visão de mundo e testemunho. 140 f. Dissertação (Mestrado em Estudos de Literatura) - Instituto de Letras, Universidade Federal Fluminense, 2010.

CURY, Jorge. Itinerário poético de Jorge de Sena - Estudo tipológico de um soneto de Jorge de Sena. In: SHARRER, Harvey L. e WILLIAMS, Frederick G. Studies on Jorge de Sena By His Colleagues and Friends. Santa Barbara, CA: Jorge de Sena Center for Portuguese Studies/ Bandanna Books, 1981.

FAGUNDES, Francisco Cota. Ser-se emigrante e exilado e como: "Em Creta, com o Minotauro". Súmula poética do drama da emigração e exílio na poesia de Jorge de Sena. In: Jorge de Sena Vinte Anos Depois: O Colóquio de Lisboa, Outubro de 1988. Edições Cosmos, Câmara Municipal de Lisboa: Lisboa, 2001.

FARIA, Almeida. Conversa à Beira-Tejo com Jorge e José. In: Jorge de Sena Vinte Anos Depois: O Colóquio de Lisboa, Outubro de 1988. Edições Cosmos, Câmara Municipal de Lisboa: Lisboa, 2001.

FERNANDES, Maria Lúcia Outeiro et al (Orgs.). Intelectuais portugueses e a cultura brasileira: depoimentos e estudos. São Paulo: Editora UNESP; Bauru, SP: EDUSC, 2002.

. A metamorfose da terra na poesia seniana. In: FERNANDES, Maria Lúcia Outeiro et al (Orgs.). Intelectuais portugueses e a cultura brasileira: depoimentos e estudos. São Paulo: Editora UNESP; Bauru, SP: EDUSC, 2002.

FRANÇA, José-Augusto. Metamorfoses de Jorge de Sena. In: Estudos sobre Jorge de Sena. Compilação, org. e introdução de Eugénio Lisboa. $1^{a}$ ed. Lisboa: Imprensa Nacional-Casa da Moeda, 1984.

GAGLIARDI, Caio. O último exílio de Jorge de Sena: Em Creta, com o Minotauro. In: Revista do CESP, v. 34, n. 51 - jan.-jun., pp. 11-24, 2014.

GUIMARÃES, Fernando. Líricas Portuguesas de Jorge de sena: uma visão da poesia dos anos 40 e 50. In: Vinte Anos Depois: O Colóquio de Lisboa, Outubro de 1988. Edições Cosmos, Câmara Municipal de Lisboa: Lisboa, 2001.

Jorge de Sena ou os limites da alteridade em poesia. In: Estudos sobre Jorge de Sena. Compilação, org. e introdução de Eugénio Lisboa. $1^{a}$ ed. Lisboa: Imprensa Nacional-Casa da Moeda, 1984.

A poesia contemporânea portuguesa e o fim da modernidade. Lisboa: Editorial Caminho, SA, 1989.

A poesia da Presença e o aparecimento do Neo-Realismo. Porto: Editorial Inova, 1969

JORGE, Silvio Renato. Jorge de Sena, um poeta sem fronteiras. In: SANTOS, Gilda (org.). Jorge de Sena: Ressonâncias e Cinqüenta Poemas. Rio de Janeiro: 7Letras, 2006.

JÚDICE, Nuno. Viagem por um século de Literatura Portuguesa. Lisboa: Relógio D’Água Editores, 1997. 
LEAL, Ana Maria Gottardi. Jorge de Sena: a modernidade da tradição. Tese (Doutorado em Literatura Portuguesa). 267 f. São Paulo: Faculdade de Filosofia, Letras e Ciências Humanas Universidade de São Paulo, 1984.

Poesia de Jorge de Sena. In: FERNANDES, Maria Lúcia Outeiro; GOBBI, Márcia Valéria Zamboni; JUNQUEIRA, Renata Soares (Orgs.). Intelectuais portugueses e a cultura brasileira: depoimentos e estudos. São Paulo: Editora UNESP; Bauru, SP: EDUSC, 2002.

LIMA, Francisco Ferreira de. De romarias, peregrinações e outras viagens. In: Revista Metamorfoses. Volume 10.2, Alfragride: Editorial Caminho e Cátedra Jorge de Sena, 2010.

LISBOA, Eugénio (Compilação, org. e introdução). Estudos sobre Jorge de Sena. $1^{a}$ ed. Lisboa: Imprensa Nacional-Casa da Moeda, 1984.

LOURENÇO, Jorge Fazenda. A Poesia de Jorge de Sena: testemunho, metamorfose, peregrinação. Lisboa: Guerra e Paz, Editores S.A, 2010.

Nem eu delicadezas vou contando: Sobre a fortuna crítica de Jorge de Sena nos anos 40. In:

Jorge de Sena Vinte Anos Depois: O Colóquio de Lisboa, Outubro de 1988. Edições Cosmos, Câmara Municipal de Lisboa: Lisboa, 2001

O essencial sobre Jorge de Sena. Lisboa: Imprensa Nacional (Casa da Moeda), 1987.

MACEDO, Helder. Jorge de Sena e poesia como testemunho. In: Revista Metamorfoses. Volume 10.2, Alfragride: Editorial Caminho e Cátedra Jorge de Sena, 2010.

MACEDO, Sebastião E.S. As metamorfoses do sujeito em Arte de Música. Dissertação (Mestrado em Letras Vernáculas - Literatura Portuguesa) - Faculdade de Letras, Universidade Federal do Rio de Janeiro, 2009.

MARINHO, Maria de Fátima. A poesia portuguesa nos meados do século XX: rupturas e continuidades. Lisboa: Editorial Caminho, 1989.

MARTINHO, Fernando J.B. Breve enquadramento da poesia de Jorge de Sena. In: Revista Colóquio/Letras (n. 37/maio). Lisboa: Fundação Calouste Gulbenkian, 1977.

Uma leitura dos sonetos de Jorge de Sena. In: SHARRER, Harvey L. e WILLIAMS, Frederick G. Studies on Jorge de Sena By His Colleagues and Friends. Santa Barbara, CA: Jorge de Sena Center for Portuguese Studies/ Bandanna Books, 1981.

Leituras na poesia de Jorge de Sena. In: Revista Colóquio/Letras (v. 67/maio). Lisboa: Fundação Calouste Gulbenkian, 1982.

Colibri, 1996.

Tendências dominantes da poesia portuguesa na década de 50. Lisboa: Edições

MONIZ, António. Para uma leitura de sete poetas contemporâneos. Lisboa: Editorial Presença, 1997.

MONTEIRO, Adolfo Casais. [A poesia de Jorge de Sena]. In: Estudos sobre Jorge de Sena. Compilação, org. e introdução de Eugénio Lisboa. $1^{a}$ ed. Lisboa: Imprensa Nacional-Casa da Moeda, 1984.

MORNA, Fátima Freitas. Poesia de Jorge de Sena. Lisboa: Editorial Comunicação, 1985.

MUHANA, Adma. Esperanças no mar se lançam. In: FERNANDES, Maria Lúcia Outeiro; GOBBI, Márcia Valéria Zamboni; JUNQUEIRA, Renata Soares (Orgs.). Intelectuais 
portugueses e a cultura brasileira: depoimentos e estudos. São Paulo: Editora UNESP; Bauru, SP: EDUSC, 2002.

QUEIROZ, Flávia Tebaldi Henriques de. Conversas com o poeta: Sena entrevistado no Brasil. In: SANTOS, Gilda (org.). Jorge de Sena: Ressonâncias e Cinqüenta Poemas. Rio de Janeiro: 7Letras, 2006.

A poesia de exílio de Jorge de Sena. 92f. Dissertação (Mestrado em Letras Vernáculas Literatura Portuguesa) - Faculdade de Letras, Universidade Federal do Rio de Janeiro, 2006.

ROSA, António Ramos. Jorge de Sena poeta. In: Estudos sobre Jorge de Sena. Compilação, org. e introdução de Eugénio Lisboa. $1^{\text {a }}$ ed. Lisboa: Imprensa Nacional-Casa da Moeda, 1984.

SALLES, Luciana. Biografias de um minotauro: Jorge de Sena e a vida que escreve a si mesma. In: MORÃO, Paula; CARMO, Carina Infante. (Org.). Escrever a Vida: Verdade e Ficção. 1ed. Lisboa: Campo das Letras, 2008, p. 339-3. Disponível em: $<$ http://www.lerjorgedesena.letras.ufri.br/ressonancias/pesquisa/ufrj/18-biografias-de-umminotauro-jorge-de-sena-e-a-vida-que-escreve-a-si-mesma/> Acesso em: 30 abr. 2014.

. Poesia e o diabo a quatro: Jorge de Sena e a escrita do diálogo. 186f. Tese (Doutorado em Letras Vernáculas - Literatura Portuguesa). Faculdade de Letras, Universidade Federal do Rio de Janeiro, 2009.

SANTOS, Gilda. Da arte de ser multiplamente português num exílio brasileiro. In: Jorge de Sena Vinte Anos Depois: O Colóquio de Lisboa, Outubro de 1988. Edições Cosmos, Câmara Municipal de Lisboa: Lisboa, 2001.

. «Como um processo testemunhal»... relances sobre a «fase brasileira» de Jorge de Sena. In: Revista Metamorfoses. Volume 10.2, Alfragride: Editorial Caminho e Cátedra Jorge de Sena, 2010.

SANTOS, Alessandro Barnabé Ferreira. Figurações da Terra natal na poesia de exílio de Jorge de Sena. 98f. Monografia (Licenciatura em Letras - Português e Inglês). Departamento de Letras, Universidade Federal do Maranhão, 2014.

SARAIVA, António J.; LOPES, Óscar. História da Literatura Portuguesa. Rio de Janeiro: Companhia Brasileira de Publicações (Porto Editora Ltda.), 1969.

SELIGMANN-SILVA, Márcio. O local do testemunho. In: Revista Metamorfoses. Volume 10.2, Alfragride: Editorial Caminho e Cátedra Jorge de Sena, 2010.

SHARRER, Harvey L. e WILLIAMS, Frederick G. Studies on Jorge de Sena By His Colleagues and Friends. Santa Barbara, CA: Jorge de Sena Center for Portuguese Studies/ Bandanna Books, 1981

SILVEIRA, Jorge Fernandes da. Uma Cadeira para Assistir ao Século XX: Reflexões sobre a Poesia de Jorge de Sena. In: SILVEIRA, Jorge Fernandes da. Verso Com Verso. Coimbra: G.C - Gráfica de Coimbra Ltda, 2003.

SILVÉRIO, Joana Prada. A metamorfose seniana: poesia e crítica na obra de Jorge de Sena. 138f. Dissertação (Mestrado em Estudos Literários) - Faculdade de Ciências e Letras, Universidade Estadual de São Paulo/Araraquara.

SIMÕES, João Gaspar. Jorge de Sena "estrangeirado". In: Estudos sobre Jorge de Sena. Compilação, org. e introdução de Eugénio Lisboa. $1^{a}$ ed. Lisboa: Imprensa Nacional-Casa da Moeda, 1984. 
Jorge de Sena e a «Presença». In: Estudos sobre Jorge de Sena. Compilação, org. e introdução de Eugénio Lisboa. $1^{\text {a }}$ ed. Lisboa: Imprensa Nacional-Casa da Moeda, 1984.

$\overline{\text { s/a. }}$. História do movimento da "Presença" - seguida de uma antologia. Coimbra: Atlântida,

Crítica - III. Lisboa: Editora Gráfica Portuguesa. s/a.

TORRES, Alexandre Pinheiro. O código científico-cosmogónico-metafísico de Perseguição, 1942, de Jorge de Sena. Lisboa: Moraes Editores, 1980.

WILLIAMS, Frederick G. Elementos estilísticos na poesia de Jorge de Sena. In: SHARRER, Harvey L. e WILLIAMS, Frederick G. Studies on Jorge de Sena By His Colleagues and Friends. Santa Barbara, CA: Jorge de Sena Center for Portuguese Studies/ Bandanna Books, 1981.

O período americano de Jorge de Sena: um testemunho pessoal. In: FERNANDES, Maria Lúcia Outeiro; GOBBI, Márcia Valéria Zamboni; JUNQUEIRA, Renata Soares (Orgs.). Intelectuais portugueses e a cultura brasileira: depoimentos e estudos. São Paulo: Editora UNESP; Bauru, SP: EDUSC, 2002.

Um exorcista prodigioso: Uma introdução à poesia de Jorge de Sena. In: Estudos sobre Jorge de Sena. Compilação, org. e introdução de Eugénio Lisboa. $1^{a}$ ed. Lisboa: Imprensa Nacional-Casa da Moeda, 1984.

\section{REFERÊNCIAS GERAIS}

ALVES, Ida Ferreira; LEMOS, Masé; NEGREIROS, Carmem (Orgs.). Estudos de Paisagem: literatura, viagens e turismo cultural. Brasil, França e Portugal. Rio de Janeiro: Oficina Raquel, 2014.

BESSE, Jean-Marc. O gosto do mundo - exercícios de paisagem. Trad. De Annie Cambe. Rio de Janeiro: EdUERJ, 2014.

COLLOT, Michel. Poética e filosofia da paisagem. Rio de Janeiro: Editora Oficina Raquel, 2013.

Rumo a uma geografia literária. In: ALVES, Ida et al (Org.) Revista Gragoatá. Niterói: EdUFF, n. 33, pp. 17-33, 2012. ISSN 1413-9073.

BACHELARD, Gaston. A poética do espaço. Trad. de Antonio de Pádua Danesi. São Paulo: Martins Fontes, 2008.

BROSSEAU, Marc. Geografia e Literatura. In: CORREAA, Roberto Lobato; ROSENDAHL, Zeny (Orgs.). Literatura, música e espaço. Rio de Janeiro: EdUERJ, 2007.

COLLOT, Michel. Do horizonte da paisagem ao horizonte dos poetas. Tradução de Eva Nunes Chatel In: Literatura e Paisagem - perspectivas e diálogos. ALVES, Ida Ferreira; FEITOSA, Márcia Manir Miguel (orgs.). Niterói: Editora da Universidade Federal Fluminense, 2010.

Pontos de vista sobre a percepção de paisagens. In: NEGREIROS, Carmem; ALVES, Ida; LEMOS, Masé (Orgs.). Literatura e Paisagem em Diálogo. Rio de Janeiro: Edições Makunaima, 
2012. Disponível em: < http://edicoesmakunaima.com/catalogo/2-critica-literaria/12-literatura-epaisagem-em-dialogo $>$ Acesso em: 22 abril. 2016.

. e ROSENDAHL, Zeny (Orgs.). Introdução à Geografia Cultural. $3^{\mathrm{a}}$ Ed. Rio de Janeiro: Bertrand Brasil, 2010.

CORRÊA, Roberto Lobato; ROSENDAHL, Zeny (Orgs.). Literatura, música e espaço. Rio de Janeiro: EdUERJ, 2007.

DARDEL, Eric. O homem e a terra: natureza da realidade geográfica. Tradução de Werther Holzer. São Paulo: Perspectiva, 2011.

EAGLETON, Terry. Teoria da literatura: uma introdução. Trad. de Waltensir Dutra. $5^{a}$ Ed. São Paulo: Martins Fontes, 2003.

FIGUEIREDO. Carmem L.N. Paisagem em três lições. In: Literatura e Paisagem - perspectivas e diálogos. ALVES, Ida Ferreira; FEITOSA, Márcia Manir Miguel (Orgs.). Niterói: Editora da Universidade Federal Fluminense, 2010.

GAGLIARDI, Caio. O último exílio de Jorge de Sena: Em Creta, com o Minotauro. In: Revista do CESP, v. 34, n. 51 - jan.-jun., pp. 11-24, 2014.

HOLZER, Werther. A Geografia Humanista: uma revisão. In: Espaço e Cultura (Edição Comemorativa, 1993-2008). Rio de Janeiro: UERJ, p. 137-147, 2008.

. Mundo e Lugar: Ensaio de Geografia. In: MARANDOLA, Eduardo; HOLZER, Werther; OLIVEIRA, Lívia (Orgs.). Qual o espaço do lugar?: geografia, epistemologia, fenomenologia. São Paulo: Perspectiva, 2012. 1999.

O lugar na Geografia Humanista. In: Revista Território, ano IV, n. 7, pp. 67-78, jul./dez.,

O conceito de lugar na Geografia Cultural-Humanista: uma contribuição para a geografia contemporânea. Revista GEOgraphia, ano V, n. 10, 2003.

LOURENÇO, Eduardo. Mitologia da saudade, seguido de Portugal como destino. São Paulo: Companhia das Letras, 1999.

MARANDOLA, Eduardo; HOLZER, Werther; OLIVEIRA, Lívia (Orgs.). Qual o espaço do lugar?: geografia, epistemologia, fenomenologia. São Paulo: Perspectiva, 2012.

MARANDOLA Jr, Eduardo. Lugar Enquanto Circunstancialidade. In: MARANDOLA, Eduardo; HOLZER, Werther; OLIVEIRA, Lívia (Orgs.). Qual o espaço do lugar?: geografia, epistemologia, fenomenologia. São Paulo: Perspectiva, 2012.

MELLO, João Baptista Ferreira de. O Triunfo do Lugar Sobre o Espaço. In: MARANDOLA, Eduardo; HOLZER, Werther; OLIVEIRA, Lívia (Orgs.). Qual o espaço do lugar?: geografia, epistemologia, fenomenologia. São Paulo: Perspectiva, 2012.

MONTAÑÉZ, Amanda Pérez. Vozes do exílio e suas manifestações nas narrativas de Julio Cortázar e Marta Traba. Londrina: Eduel, 2013.

PAZ, Octavio. O arco e a lira. Trad. de Ari Roitman e Paula Wacht. 2a Ed. São Paulo: Cosac Naify, 2012.

Os Filhos do Barro: do romantismo à vanguarda. Trad. de Ari Roitman e Paulina Wacht. 2a Ed. São Paulo: Cosac Naify, 2013. 
OLIVEIRA, Lívia. O Sentido de Lugar. In: MARANDOLA, Eduardo; HOLZER, Werther; OLIVEIRA, Lívia (Orgs.). Qual o espaço do lugar?: geografia, epistemologia, fenomenologia. São Paulo: Perspectiva, 2012.

. Sentido de Lugar e de Topofilia. In: Revista Geograficidade, v. 3, n. 2, Inverno de 2013. ISSN: 2238-0205.

QUEIROZ, Flávia Tebaldi Henriques de. A poesia de exílio de Jorge de Sena. 2006. Dissertação (Mestrado em Literatura Portuguesa) - Faculdade de Letras, Universidade Federal do Rio de Janeiro, 2006.

REPLH, Edward. Reflexões Sobre a Emergência, Aspectos e Essências de Lugar. In: MARANDOLA, Eduardo; HOLZER, Werther; OLIVEIRA, Lívia (Orgs.). Qual o espaço do lugar?: geografia, epistemologia, fenomenologia. São Paulo: Perspectiva, 2012.

SAID, Edward. Reflexões sobre o exílio e outros ensaios. Tradução de Pedro Maia Soares. São Paulo: Companhia das Letras, 2003.

SAUER, Carl O. Geografia Cultural. 1931, In: CORRÊA, Roberto Lobato; ROSENDAHL, Zeny (Orgs.). Introdução à Geografia Cultural. $3^{a}$ Ed. Rio de Janeiro: Bertrand Brasil, 2010.

SOKOLOWSKI, Robert. Introdução à fenomenologia. $2^{a}$ Ed. São Paulo: Edições Loyola, 2010. TODOROV, Tzvetan. O Homem Desenraizado. Trad. de Cristina Cabo. Rio de Janeiro: Record, 1999.

TUAN, Yi-Fu. Espaço e lugar: a perspectiva da experiência. Trad. Lívia de Oliveira. Londrina: Eduel, 2013.

Topofilia: um estudo da percepção, atitudes e valores do meio ambiente. Trad. de Lívia de Oliveira. Londrina: Eduel, 2012.

Paisagens do medo. São Paulo: Editora da UNESP, 2006.

VOLPE, Miriam L. Geografias de Exílio. Juiz de Fora: Editora da UFJF, 2005.

WAGNER, Philip; MIKESELL, Marvin. Os temas da Geografia Cultural. Tradução de Olívia de Barros Lima da Silva. In: CORREAA, Roberto Lobato; ROSENDAHL, Zeny (Orgs.). Introdução à Geografia Cultural. $3^{\text {a }}$ Ed. Rio de Janeiro: Bertrand Brasil, 2010.

POZENATO, José Clemente. As rimas de Guido Cavalcanti: uma introdução. In: Revista Morus: Utopia e Renascimento, n. 11, 2016.

Ler Jorge de Sena: http://www.lerjorgedesena.letras.ufrj.br/

Revista Colóquio/Letras: http://www.coloquio.gulbenkian.pt/

50 anos de estatística em educação, vol. 1. Lisboa: Gabinete de Estatística e Planejamento da Educação, 2009. Disponível em: < www.ine.pt $>$ 


\title{
ANEXOS
}

\author{
ANEXO A
}

\section{«LA CATHÉDRALE ENGLOUTIE», DE DEBUSSY}

Creio que nunca perdoarei o que me fez esta música. Eu nada sabia de poesia, de literatura, e o piano era, para mim, sem distinção entre a Viúva Alegre e Mozart, o grande futuro paralelo a tudo o que eu seria para satisfação dos meus parentes todos. Mesmo a Música, eles achavam-na demais, imprópria de um rapaz que era pretendido igual a todos eles: alto ou baixo funcionário público, civil ou militar. Eu lia muito, é certo. Lera

o Ponson du Terrail, o Campos Júnior, o Verne e o Salgari, e o Eça e o Pascoaes. E lera também nuns caderninhos que me eram permitidos [porque aperfeiçoavam o francês, e a Livraria Larousse editava para crianças mais novas do que eu era, a história da catedral de Ys submersa nas águas.

Um dia, no rádio Pilot da minha Avó, ouvi uma série de acordes aquáticos, que os pedais faziam pensativos, mas cujas dissonâncias eram a imagem tremulante daquelas fendas ténues que na vida, na minha e na dos outros, ou havia ou faltavam. Foi como se as águas se me abrissem para ouvir os sinos, os cânticos, e o eco das abóbadas, e ver as altas torres sobre que as ondas glaucas se espumavam tranquilas. Nas naves povoadas de limos e de anémonas, vi que perpassavam almas penadas como as do Marão e que eu temia em todos os estalidos e cantos escuros da casa.

Ante um caderno, tentei dizer tudo isso. Mas só a música que comprei e estudei ao piano mo ensinou mas sem palavras. Escrevi. Como o vaso da China, pomposo e com dragões em relevo, que havia na sala, e que uma criada ao espanejar partiu, e dele saíram lixo e papéis velhos lá caídos, as fissuras da vida abriram-se-me para sempre, ainda que o sentido de muitas eu só entendesse mais tarde.

Submersa catedral inacessível! Como perdoarei aquele momento em que do rádio vieste, solene e vaga e grave, de sob as águas que marinhas me seriam meu destino perdido? É desta imprecisão que eu tenho ódio: 
nunca mais pude ser eu mesmo - esse homem parvo que, nascido do jovem tiranizado e triste, viveria tranquilamente arreliado até à morte.

Passei a ser esta soma teimosa do que não existe: exigência, anseio, dúvida e gosto de impor aos outros a visão profunda, não a visão que eles fingem, mas a visão que recusam: esse lixo do mundo e papéis velhos que sai dum jarrão exótico que a criada partiu, como a catedral se irisa em acordes que ficam na memória das coisas como um livro infantil de lendas de outras terras que não são a minha.

Os acordes perpassam cristalinos sob um fundo surdo que docemente ecoa. Música literata e fascinante, nojenta do que por ela em mim se fez poesia, esta desgraça impotente de actuar no mundo, e que só sabe negar-se e constranger-me a ser o que luta no vácuo de si mesmo e dos outros.

Ó catedral de sons e de água! Ó música sombria e luminosa! Ó vácua solidão tranquila! Ó agonia doce e calculada! Ah como havia em ti, tão só prelúdio, tamanho alvorecer, por sob ou sobre as águas, de negros sóis e brancos céus nocturnos? Eu hei-de perdoar-te? Eu hei-de ouvir-te ainda? Mais uma vez eu te ouço, ou tu, perdão, me escutas?

$31 / 12 / 1964$

(SENA, 2013, p. 385-7)

In: Arte de Música (1968) 
ANEXO B

\section{CARTA AOS MEUS FILHOS SOBRE OS FUZILAMENTOS DE GOYA}

Não sei, meus filhos, que mundo será o vosso. É possível, porque tudo é possível, que ele seja aquele que eu desejo para vós. Um simples mundo, onde tudo tenha apenas a dificuldade que advém de nada haver que não seja simples e natural. Um mundo em que tudo seja permitido, conforme o vosso gosto, o vosso anseio, o vosso prazer, o vosso respeito pelos outros, o respeito dos outros por vós. E é possível que não seja isto, nem seja sequer isto o que vos interesse para viver. Tudo é possível, ainda quando lutemos, como devemos lutar, por quanto nos pareça a liberdade e a justiça, ou mais que qualquer delas uma fiel dedicação à honra de estar vivo. Um dia sabereis que mais que a humanidade não tem conta o número dos que pensaram assim, amaram o seu semelhante no que ele tinha de único, de insólito, de livre, de diferente, e foram sacrificados, torturados, espancados, e entregues hipocritamente à secular justiça, para que os liquidasse «com suma piedade e sem efusão de sangue.» Por serem fiéis a um deus, a um pensamento, a uma pátria, uma esperança, ou muito apenas à fome irrespondível que lhes roía as entranhas, foram estripados, esfolados, queimados, gaseados, e os seus corpos amontoados tão anonimamente quanto haviam

[vivido,

ou suas cinzas dispersas para que delas não restasse memória.

Às vezes, por serem de uma raça, outras

por serem de urna classe, expiaram todos os erros que não tinham cometido ou não tinham consciência de haver cometido. Mas também aconteceu e acontece que não foram mortos.

Houve sempre infinitas maneiras de prevalecer, aniquilando mansamente, delicadamente, por ínvios caminhos quais se diz que são ínvios os de Deus. Estes fuzilamentos, este heroísmo, este horror, foi uma coisa, entre mil, acontecida em Espanha há mais de um século e que por violenta e injusta ofendeu o coração de um pintor chamado Goya, que tinha um coração muito grande, cheio de fúria e de amor. Mas isto nada é, meus filhos. Apenas um episódio, um episódio breve, nesta cadela de que sois um elo (ou não sereis) de ferro e de suor e sangue e algum sémen 
a caminho do mundo que vos sonho.

Acreditai que nenhum mundo, que nada nem ninguém vale mais que uma vida ou a alegria de tê-la.

É isto o que mais importa - essa alegria.

Acreditai que a dignidade em que hão-de falar-vos tanto não é senão essa alegria que vem

de estar-se vivo e sabendo que nenhuma vez alguém está menos vivo ou sofre ou morre

para que um só de vós resista um pouco mais

à morte que é de todos e virá.

Que tudo isto sabereis serenamente,

sem culpas a ninguém, sem terror, sem ambição,

e sobretudo sem desapego ou indiferença,

ardentemente espero. Tanto sangue,

tanta dor, tanta angústia, um dia

- mesmo que o tédio de um mundo feliz vos persiga -

não hão-de ser em vão. Confesso que

multas vezes, pensando no horror de tantos séculos

de opressão e crueldade, hesito por momentos

e uma amargura me submerge inconsolável.

Serão ou não em vão? Mas, mesmo que o não sejam, quem ressuscita esses milhões, quem restitui

não só a vida, mas tudo o que lhes foi tirado?

Nenhum Juízo Final, meus filhos, pode dar-lhes

aquele instante que não viveram, aquele objecto

que não fruíram, aquele gesto

de amor, que fariam «amanhã».

E. por isso, o mesmo mundo que criemos

nos cumpre tê-lo com cuidado, como coisa

que não é nossa, que nos é cedida

para a guardarmos respeitosamente

em memória do sangue que nos corre nas veias,

da nossa carne que foi outra, do amor que

outros não amaram porque lho roubaram.

Lisboa, 25/6/1959

(SENA, 2013, p. 346-351)

In: Metamorfoses, seguidas de Quatro Sonetos a Afrodite Anadiómena (1963) 


\section{ANEXO C}

\section{EM CRETA, COM O MINOTAURO}

Nascido em Portugal, de pais portugueses, e pai de brasileiros no Brasil, serei talvez norte-americano quando lá estiver.

Coleccionarei nacionalidades como camisas se despem, se usam e se deitam fora, com todo o respeito necessário à roupa que se veste e que prestou serviço. Eu sou eu mesmo a minha pátria. A pátria de que escrevo é a língua em que por acaso de gerações nasci. E a do que faço e de que vivo é esta raiva que tenho de pouca humanidade neste mundo quando não acredito em outro, e só outro quereria que este mesmo fosse. Mas, se um dia me esquecer de tudo, espero envelhecer tomando café em Creta com o Minotauro, sob o olhar de deuses sem vergonha.

O Minotauro compreender-me-á.

Tem cornos, como os sábios e os inimigos da vida. É metade boi e metade homem, como todos os homens. Violava e devorava virgens, como todas as bestas. Filho de Pasifaë, foi irmão de um verso de Racine, que Valéry, o cretino, achava um dos mais belos da "langue". Irmão também de Ariadne, embrulharam-no num novelo de que

[se lixou.

Teseu, o herói, e, como todos os gregos heróicos, um filho da puta, riu-lhe no focinho respeitável.

O Minotauro compreender-me-á, tomará café comigo, enquanto o sol serenamente desce sobre o mar, e as sombras, cheias de ninfas e de efebos desempregados, se cerrarão dulcíssimas nas chávenas, como o açúcar que mexeremos com o dedo sujo de investigar as origens da vida.

\section{III}

É aí que eu quero reencontrar-me de ter deixado a vida pelo mundo em pedaços repartida, como dizia aquele pobre diabo que o Minotauro não leu, porque, como toda a gente, não sabe português. 
Também eu não sei grego, segundo as mais seguras informações.

Conversaremos em volapuque, já

que nenhum de nós o sabe. O Minotauro

não falava grego, não era grego, viveu antes da Grécia, de toda esta merda douta que nos cobre há séculos, cagada pelos nossos escravos, ou por nós quando somos os escravos de outros. Ao café, diremos um ao outro as nossas mágoas.

\section{IV}

Com pátrias nos compram e nos vendem, à falta de pátrias que se vendam suficientemente caras para haver vergonha] de não pertencer a elas. Nem eu, nem o Minotauro, teremos nenhuma pátria. Apenas o café, aromático e bem forte, não da Arábia ou do Brasil, da Fedecam, ou de Angola, ou parte alguma. Mas café contudo e que eu, com filial ternura, verei escorrer-lhe do queixo de boi até aos joelhos de homem que não sabe de quem herdou, se do pai, se da mãe, os cornos retorcidos que lhe ornam a nobre fronte anterior a Atenas, e, quem sabe, à Palestina, e outros lugares turísticos, imensamente patrióticos.

Em Creta, com o Minotauro, sem versos e sem vida, sem pátrias e sem espírito, sem nada, nem ninguém, que não o dedo sujo, hei-de tomar em paz o meu café.

$$
5 / 7 / 1965
$$

(SENA, 2013, p. 516-8)

In: Peregrinatio ad Loca Infecta (1969) 


\section{ANEXO D \\ O ECUMENISMO LUSITANO OU A DUPLA NACIONALIDADE}

Pela porta lateral da catedral em Colónia

(construída - è vero - para os ossos dos Reis Magos)

eu saía para o branco sol da manhã de inverno, quando um rumor de português subia em negro shábitos a escada. Freiras a quem falei sim brasileiras sim peregrinas de pouso em pouso a Roma. Quando eu disse que eu era brasileira a madre cujo véu rodeava um rosto emaciado e luso disse: - Ah, naturalizado, não é brasileiro O outro caso foi em Hamburgo na Hauptbahnhof. O quiosque dos jornais de todas as línguas. Chega uma mulher morena - um traço dentro de opulentas peles - e pergunta Por jornais lusitanos em alemão razoável.

Era evidente que só um português dos tais desejaria em Hamburgo informar-se assim do estado do universo. É portuguesa? Sou. Palavra puxa palavra, Eu também era. Mas ela exclamou:

- Brasileiro naturalizado? Ah, não é português -. E voltou-se as costas com o periódico na mão, equilibrando as pernas ainda de varina dificilmente nos tacões finíssimos.

$$
20 / 1 / 1970
$$

(SENA, 2013, p. 631)

In: Exorcismos (1972) - parte IV 
ANEXO E

\section{À MEMÓRIA DE KAZANTZAKIS, E A QUANTOS FIZERAM O FILME «ZORBA THE GREEK»}

Deixa os gregos os gregos em paz, recomendou uma vez um poeta a outro que falava de gregos. Mas este poeta, o que falava de gregos, não pensava neles ou na Grécia. O outro também não. Porque um pensava em estátuas brancas e na beleza delas e na liberdade de adorá-las sem folha de parra, que nem mesmo os próprios deuses são isentos hoje de ter de usar. E o outro apenas detestava, nesse falar de gregos, não a troca falsa dos deuses pelos corpos, mas o que lhe parecia traição à nossa vida amarga, em nome de evasões (que talvez não houvesse) para um passado revoluto, extinto, e depilado.

Apenas Grécia nunca houve como essa inventada nos compêndios pela nostalgia de uma harmonia branca. Nem a Grécia deixou de ser - como nós não - essa barbárie cínica, essa violência racional e arguta, uma áspera doçura do mar e da montanha, das pedras e das nuvens, e se caiadas casas com harpias negras que sob o azul do céu persistem dentro em nós, tão sórdidas, tão puras - as casas e as harpias e a paisagem idem - como agrestes ilhas sugando secas todo o vento em volta.

E que não só persistem. Porque as somos: ou tendo-as circunstantes, ou em faces, gestos, que vão do Atlântico ao Mar Negro, ou vendo-as não só em sonhos, mas nesta odisseia de quem, como de Ulisses, uma vida inteira é qual regresso à pátria demorado para que apenas de velhice ainda a aceitemos.

$\mathrm{Na}$ Grécia todavia, e mais que em Grécia Creta, isso que somos regrediu. Distância muito maior existe em ter ficado igual num mundo que mudou, e em ter ficado o mesmo, vivendo como de hoje, entre as antigas pedras guardando em si o mugir do Minotauro (e os gritos virginais das suas vítimas), que, em como nós, não ter nascido ali mas onde apenas derradeiros gregos vieram. 
Por isso, este vibrar de cordas que é uma dança de homens saltando delicados em furioso êxctase perante a própria essência de estar vivo (ó Diónisis, ó Moiras, ó sinistras sombras) nos fascina tanto. O que é profundo volta, o que está longe volta, o que está perto é longe, e o que nos paira n'alma é uma distância elísia.

No lapidar-se a viúva que resiste aos homens Para entregar-se àquele que hesita em possuí-la e a quem, Centauro, Zorba dá conselhos de viver-se implume bípede montado na trípode do sexo que transforma em porcos os amantes de Circe, mas em homens aqueles que a violam; nesta prostituta que, sentimental, ainda vaidosa, uma míseria d'Art Nouveau trazida por impérios disputando Creta, será na morte o puro nada feminino que as harpias despem; e neste Zorba irresponsável, cru, que se agonia no mar revolto da odisseia, mas perpassa incólume entre a dor e a morte, entre a miséria e o vício, entre a guerra e a paz, para pousar a mão nesse ombro juvenil de quem não é Telémaco - há nisto, e na rudeza com que esta terra é terra, e o mar é mar, e a praia praia, o tom exacto de uma música divina. Os deuses, se os houve alguma vez, eram assim. E, quando se esqueciam contemplando o escasso formigar da humanidade que tinha cidades como aldeias destas, neles (como num sexo que palpita e engrossa) Vibrava este som claro de arranhadas cordas que o turvo som das percussões pontua.

Deixemos, sim, em paz os gregos. Mas, nus ou vestidos, menos do que humanos, eles divinamente são a guerra em nós. Ah não as guerras sanguinárias, o sofrer que seja o bem e o mal, e a dor de não ser livre. Mas sim o viver com fúria, este gastar da vida, este saber que a vida é coisa que se ensina, mas não se aprende. Apenas pode ser dançada.

Madinson, Janeiro 1966

(SENA, 2013, p. 528-531) 


\section{ANEXO F}

\section{NOUTROS LUGARES}

Não é que ser possível ser feliz acabe, quando se aprende a sê-lo com bem pouco. Ou que não mais saibamos repetir o gesto que mais prazer nos dá, ou que daria a outrem um prazer irresistível. Não: o tempo nos afina e nos apura: faríamos o gesto com infinda ciência. Não é que passem as pessoas, quando o nosso pouco é feito da passagem delas. Nem é também que ao jovem seja dado o que a mais velhos se recusa. Não.

É que os lugares acabam. Ou ainda antes de serem destruídos, as pessoas somem, e não mais voltam onde parecia que elas ou outras voltariam sempre por toda a eternidade. Mas não voltam, desviadas por razões ou por razão nenhuma.

É que as maneiras, modos, circunstâncias mudam. Desertas ficam praias que brilhavam não de água ou sol mas solta juventude. As ruas rasgam casas onde leitos já frios e lavados não rangiam mais. E portas encostadas só se abrem sobre a treva que nenhuma sombra aquece.

O modo como tínhamos ou víamos, em que com tempo o gesto sempre o mesmo faríamos com ciência refinada e sábia (o mesmo gesto que seria útil, se o modo e a circunstância persistissem), tornou-se sem sentido e sem lugar.

Os outros passam, tocam-se, separam-se, exactamente como dantes. Mas aonde e como? Aonde e como? Quando? Em que praias, que ruas, casas, e quais leitos, a que horas do dia ou da noite, não sei. Apenas sei que as circunstâncias mudam e que os lugares acabam. E que a gente não volta ou não repete, e sem razão, o que só por acaso era a razão dos outros.

Se do que vi ou tive uma saudade sinto, feita de raiva e do vazio gélido, 
não é saudade, não. Mas muito apenas

o horror de não saber como se sabe agora

o mesmo que aprendi. E a solidão

de tudo ser igual doutra maneira.

$\mathrm{E}$ o medo de que a vida seja isto:

um hábito quebrado que se não reata,

senão noutros lugares que não conheço.

Madinson, 21/1/1967

(SENA, 2013, p. 533-4)

In: Peregrinatio ad Loca Infecta (1969) 
ANEXO G

\section{À MEMÓRIA DE ADOLFO CASAIS MONTEIRO}

Como se morre, Adolfo? Tu morreste

(toca o telefone às duas da manhã em Lourenço Marques era a Joaninha em lágrimas a dizer que o padrinho dela tinha morrido eu não queria crer e mesmo perguntei - tendo tantos compadres - quem era o padrinho dela cuja morte chegava em notícia de Lisboa a Mécia e eu ficámos silenciosos com os olhos marejados das lágrimas que só vieram no dia seguinte esperávamos mais dia menos dia tão doente estavas aquela notícia agora mais incrível por chegada inopinadamente do outro lado do mundo que não era sequer aquele em que morrias)

— e diz-me o Pimentel numa carta tão triste: enquanto dormias a tua solidão e estavas morto e sereno pela manhã alta. Morreste na mesma solidão altiva e tímida com que foras discreção e delicado ser escondido em máscaras de sorriso amargo e de palavras ásperas e rudes. Igual aos versos que escreveste como raros no molhar de alma em sangue e sentimento já essência e só profunda vida oculta em música puríssima de câmara em cordas tensas a que o ranger dos arcos se somava ambíguo. Ninguém mais nobremente ergueu em si o monumento da morte esse viver contínuo num só de se indicarem por oblíquos sinais os gestos limpos da amizade e os limpos mais ainda de um amor constante que o teu corpo buscou em tantas mulheres amando só algumas fielmente na tortura de não se amar tão bem quanto o desejo. Adolescente, amadureceste para uma velhice a que te deste como monge laico incréu de tudo menos desse amor perdido que à tua volta, em livros como em música, era um sussurro de memórias silentes a rodear-te de vácuo a tua sala vazia. Como se morre, Adolfo? Trinta e três anos - uma idade perfeita - conheci-te, soube de ti o dito e o não-dito, o que escreveste e o que não escreveste. Por instantes, os teus olhos cruzavam-se num viés de vesgo que era um saber terrível de estar só no mundo e não haver que valha a pena que se diga sem destruir-se quanto em nossa vida é o pouco indestrutível se guardado à força 
num silêncio de exílio e de distância.

E todavia como estiveste no mundo, como

duramente bebeste toda a dor do mundo, ou a fumaste em nuvens de cigarros que matavam os teus pulmões possessos de asfixia.

Foste o estrangeiro e o exilado perfeito

e por todos nós que recusámos de um salto por outras terras esta terra há séculos de outrem, morreste em dignidade, sem queixas nem saudades a queixa e a saudade mais pesadas pesadas para o fundo, sem palavras que as não há entendíveis aonde não se entende a perfeição tranquila em desespero agudo a que te deste num morrer sem voz. Morreste só, como viveste. Sem conversa, como escolheste viver. Longe de tudo, como a vida te deu que tu viveras. E tão presente, mesmo se esquecido, és como o fogo ardente a requelmar quem pensa que em Portugal de Portugal se é.

Como se morre? Nesse instante extremo, sentiste um respirar que te alargava e te expandia o peito mais os olhos até os confins deste universo inteiro? Abriste os olhos? Só em sonhos viste? Morreste - como se morre? - E no teu rosto qual nos teus versos poderá ser lido até que nem pensaste nem disseste. Mas isso tu sabias, e creio que foi pouco oh muito pouco o que a morte foi capaz de te ensinar.

Porto, 26/8/1972

(SENA, 2013, p. 669-672)

In: Conbeço o Sal... e outros poemas (1974) 


\section{ANEXO H}

\section{RAÍZES}

Raízes? Nem mesmo todas as plantas têm, E o termo cheira às gritarias de Barrès (où voulez-vous que je m'enracine? - perguntava-lhe o Gide) ou quejandas companhias galicanas pré-fascitas, quando desejavam - patriotas - que franceses fossem a Alsácia e a Lorena tão germânicas.

Tudo isto acabou triste em 45 - e o velho da Action Française não foi fuzilado por colaboracionista e denunciador de resistentes, atendendo-se à sua idade (oh le prestigie de la littérature!). Raízes? Como - por metáfora - se ganham ou se perdem? Sendo filho? Sendo pai? As duas coisas? Vivendo aqui na pátria ou mais ou menos do que quantos anos? Perderam-nas Camões e Mendes Pinto no Oriente?

Ganhou-as Eça nos seus exílios de cônsul? Manteve-as fumos de ópio aquele Camilo apenas Pessanha por Macau? Ganhou-as Pessoa tão inglês de sul das Áfricas, no seu tão esperto exílio de Lisboa? E o Vieira padre e brasileiro na Bahia, largara-as lá por Roma à Cristina da Suécia? Miguéis em Nova-York? O Pimentel das Memórias perdeu-as em São Paulo? Este país - que sempre isto pergunta aonde tem raízes? Certamente que à volta de Paris - com um milhão de raízes a fazer filhos (e não porque em Paris se escreva ou se traduza o lido em Portugal) E isto é velho como o mundo: ao grego Heródoto uns gregos que ele achou pelos Egitos, aos quais - tu quoque... - perguntou pelas raízes, apontaram-lhe num gesto (lusitano) qual a raiz que tinham radicado neles. Raízes outras há: os mortos que nos dormem na terra em que nascemos, na terra onde morreram, e nos vivem na vida que não tendes nesta Europa finis pilritos fêmeas de outro mundos machos.

Porto, 25 Agosto 72

(SENA, 2013, p. 668-9) 